B O N N E V I L L E P O W E R A D M I N I S T R A T I O Washington Phase II Fish Diversion Screen Evaluations in the Yakima River Basin

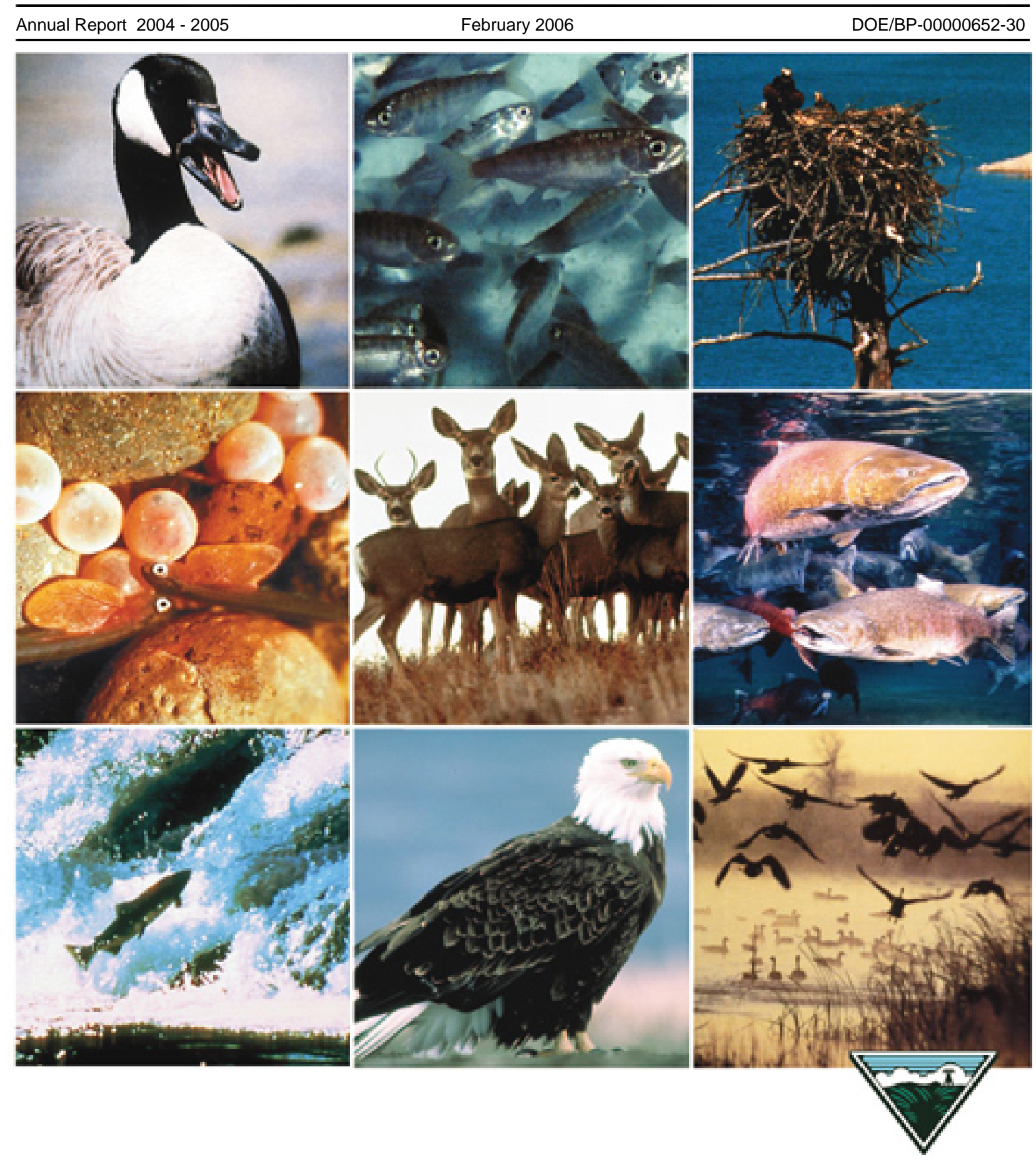


This Document should be cited as follows:

Vucelick, Jessica, Geoffrey McMichael, Mickie Chamness, "Washington Phase II Fish Diversion Screen Evaluations in the Yakima River Basin", 2004-2005 Annual Report, Project No. 198506200, 78 electronic pages, (BPA Report DOE/BP-00000652-30)

\section{Bonneville Power Administration}

P.O. Box 3621

Portland, OR 97208

This report was funded by the Bonneville Power Administration (BPA), U.S. Department of Energy, as part of BPA's program to protect, mitigate, and enhance fish and wildlife affected by the development and operation of hydroelectric facilities on the Columbia River and its tributaries. The views in this report are the author's and do not necessarily represent the views of BPA. 


\title{
Yakima River Basin Phase II Fish Screen Evaluations, 2004
}

\author{
Annual Report
}

April 2004 - April 2005

\author{
Prepared by: \\ Jessica A. Vucelick, Geoffrey A. McMichael, and Mickie A. Chamness \\ Pacific Northwest National Laboratory \\ P.O. Box 999 \\ Richland, Washington 99352
}

Prepared for:

U.S. Department of Energy

Bonneville Power Administration

Division of Fish and Wildlife

P.O. Box 3621

Portland, Oregon 97208-3621

Project number: 1985-062-00

Contract number: 00000652-0017

February 2005 


\section{Summary}

In 2004, the Pacific Northwest National Laboratory (PNNL) evaluated 25 Phase II fish screen sites in the Yakima River Basin as part of a multi-year project for the Bonneville Power Administration on the effectiveness of fish screening devices. PNNL collected data to determine whether velocities in front of the screens and in the bypasses met the National Oceanic and Atmospheric Administration Fisheries (NOAA Fisheries, formerly the National Marine Fisheries Service (NMFS)) criteria to promote safe and timely fish passage. In addition, PNNL conducted underwater video surveys to evaluate the environmental and operational conditions of the screen sites with respect to fish passage.

Based on evaluations in 2004, PNNL concluded that

- In general, water velocity conditions at the screen sites met fish passage criteria set by NOAA Fisheries.

- Conditions at most facilities would be expected to provide for safe juvenile fish passage.

- Automated cleaning brushes generally functioned properly; chains and other moving parts were typically well-greased and operative.

- Removal of sediment buildup and accumulated leafy and woody debris could be improved at some sites.

- Conditions at some facilities indicate that operation and/or maintenance should be modified to improve passage conditions for juvenile fish. For example, Taylor has had problems meeting bypass flow and submergence operating criteria since the main river channel shifted away from the site 2 years ago, and Fruitvale consistently has had problems meeting bypass flow criteria when the water is low.

- Continued problems at Gleed point to design flaws. This site should be considered for redesign or replacement. 


\section{Acknowledgments}

The successful completion of this project depended on the involvement and cooperation of many people. Jonathan McCloud, Bonneville Power Administration, directed the project. John Easterbrooks, Ray Gilmour, David Floyd, and Pat Schille, Washington Department of Fish and Wildlife, and Tom Leonard, U.S. Bureau of Reclamation, provided valuable background information on the sites and also comments on the operation and maintenance of individual sites. Traci Degerman, Kate Deters, Dan Tano, and Susan Thorsten, Pacific Northwest National Laboratory, assisted with the field work. 


\section{Abbreviations and Acronyms}

$\begin{array}{ll}\text { ADV } & \text { acoustic Doppler velocimeter } \\ \text { BPA } & \text { Bonneville Power Administration } \\ \text { cfs } & \text { cubic feet per second } \\ \text { ft/s } & \text { feet per second } \\ \text { NMFS } & \text { National Marine Fisheries Service } \\ \text { NOAA } & \text { National Oceanic and Atmospheric Administration } \\ \text { NPPC } & \text { Northwest Power Planning Council } \\ \text { PNNL } & \text { Pacific Northwest National Laboratory } \\ \text { RMS } & \text { root mean square } \\ \text { USBR } & \text { U.S. Bureau of Reclamation } \\ \text { WDFW } & \text { Washington Department of Fish and Wildlife } \\ \text { WIP } & \text { Wapato Irrigation Project }\end{array}$




\section{Contents}

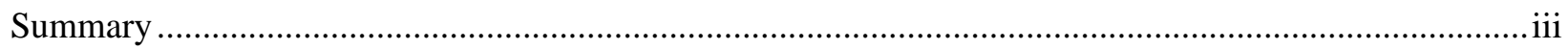

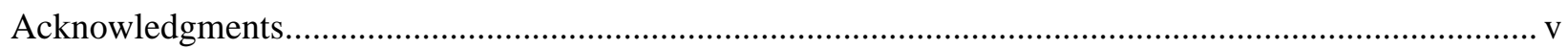

Abbreviations and Acronyms ................................................................................................... vii

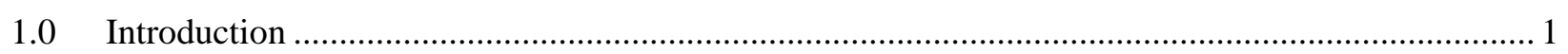

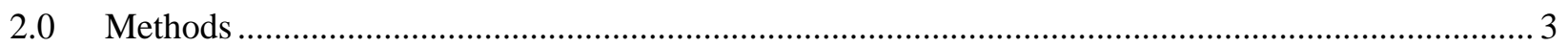

$2.1 \quad$ Water Velocity Measurements ....................................................................................... 4

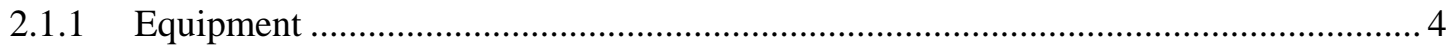

2.1.2 Data Collection and Analyses .............................................................................. 5

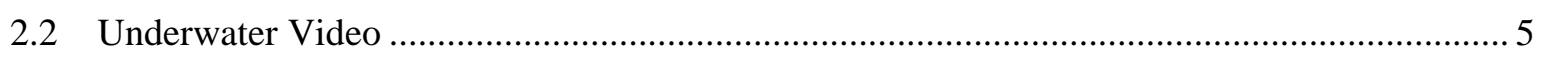

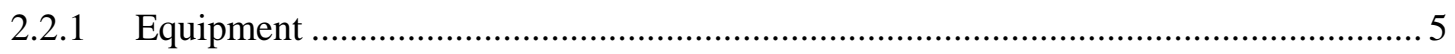

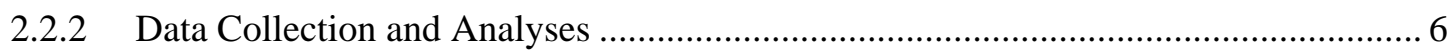

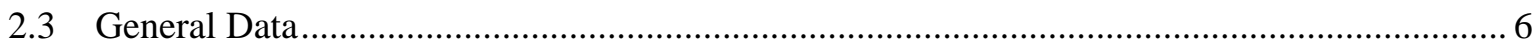

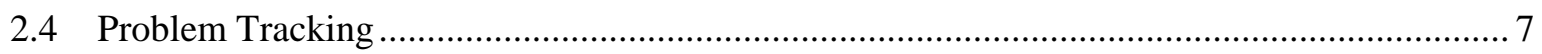

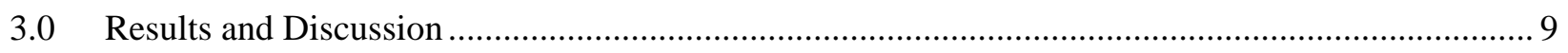

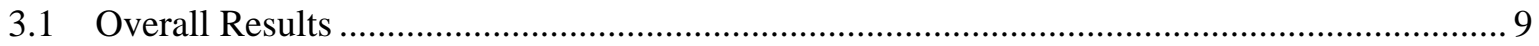

3.1.1 Water Velocity Measurements ……….................................................................... 9

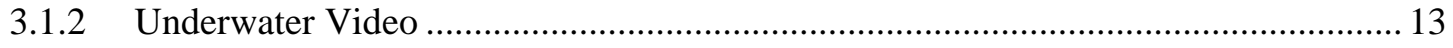

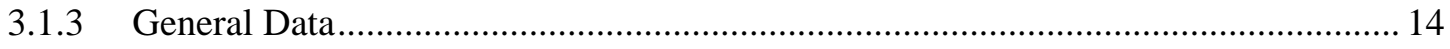

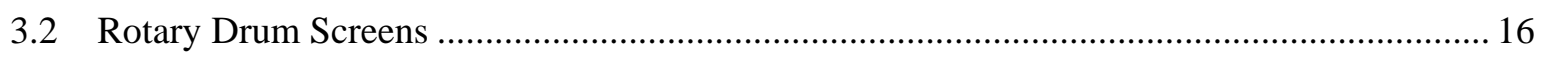

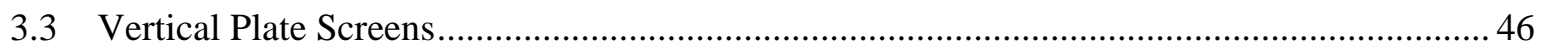

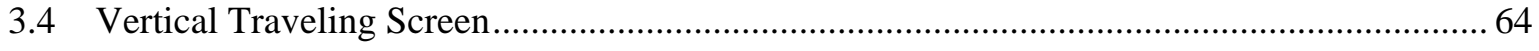

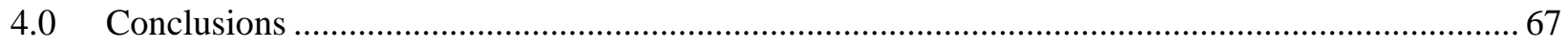

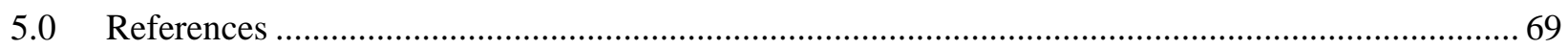

\section{Figures}

1 Yakima River Basin Phase II fish screen facilities ......................................................................... 3

2 Acoustic Doppler velocimeter probe equipment and the Marsh-McBirney $511 \circledast$ velocity meter ........ 4

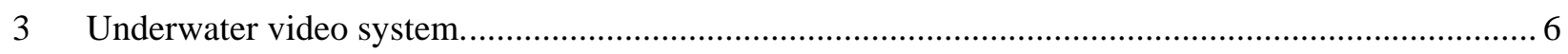

4 Mean approach, sweep, and bypass velocities at Phase II fish screen facilities in the Yakima River Basin in 2004 shown against a reference line for the NOAA Fisheries approach criteria........ 13

5 Water velocities and sediment accumulation at Bachelor-Hatton in May 2004............................... 17

$6 \quad$ Water velocities and sediment accumulations at Bachelor-Hatton in June 2004 ............................. 17

$7 \quad$ Water velocities and sediment depths at Clark in May 2004.......................................................... 18 


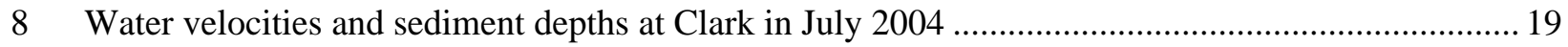

9 Water velocities and sediment depths at Clark in September 2004 ............................................... 19

10 Water beginning to overtop the headgates at Clark in May 2004................................................... 20

11 Water velocities and sediment levels at Congdon in May 2004 .................................................... 21

12 Water velocities and sediment depths at Congdon in July 2004...................................................2

13 Water velocities and sediment depths at Congdon in September 2004 ............................................. 22

14 Water velocities and sediment depths at John Cox in May 2004 ................................................. 23

15 Water velocities and sediment depths at John Cox in June 2004 ..................................................2 23

16 Water velocities and sediment depths at John Cox in September 2004...........................................24

17 Water velocities and sediment depths at Kelly-Lowry in May 2004 ............................................ 25

18 Water velocities and sediment depths at Kelly-Lowry in July 2004 ..............................................25

19 Water velocities and sediment depths at Kelly-Lowry in September 2004 ..................................... 26

20 Water velocities and sediment depths at Lindsey in May 2004.................................................... 27

21 Water velocities and sediment depths at Lindsey in June 2004 .................................................2

22 Water velocities and sediment depths at Lindsey in September 2004 ............................................. 28

23 Water velocities and sediment depths at Lower Wapato Irrigation Project in May 2004 ................. 29

24 Water velocities and sediment depths at Lower Wapato Irrigation Project in June 2004 ................. 29

25 Water velocities and sediment depths at Naches-Cowiche in May 2004 ....................................... 30

26 Water velocities and sediment depths at Naches-Cowiche in June 2004 ....................................... 31

27 Water velocities and sediment depths at Naches-Cowiche in September 2004_.............................. 31

28 Water velocities and sediment depths at New Cascade in May 2004.............................................. 32

29 Water velocities and sediment depths at New Cascade in June 2004 ............................................ 33

30 Water velocities and sediment depths at New Cascade in September 2004 ...................................... 33

31 Water velocities and sediment depths at Powell-LaFortune in May 2004....................................... 34

32 Water velocities and sediment depths at Powell-LaFortune in July 2004 .........................................35

33 Water velocities and sediment depths at Powell-LaFortune in September 2004 ............................... 35

34 Water velocities and sediment depths at Snipes-Allen in May 2004............................................... 36

35 Water velocities and sediment depths at Snipes-Allen in June 2004 .............................................. 37

36 Water velocities and sediment depths at Snipes-Allen in September 2004 ..................................... 37

37 Water velocities and sediment depths at Taylor in May 2004 ....................................................... 38

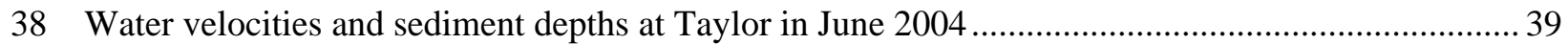

39 Water velocities and sediment depths at Toppenish Pump in May 2004 ........................................ 40

40 Water velocities and sediment depths at Toppenish Pump in June 2004 ........................................ 40

41 Water velocities and sediment depths at Toppenish Pump in September 2004................................ 41

42 Water velocities and sediment depths at Upper Wapato Irrigation Project in May 2004..................42

43 Water velocities and sediment depths at Upper Wapato Irrigation Project in June 2004.................. 42

44 Underwater video pictures from Upper WIP in May and June...................................................... 43

45 Water velocities and sediment depths at Wilson Creek in May 2004...............................................4 44 
46 Water velocities and sediment depths at Wilson Creek in June 2004............................................ 45

47 Water velocities and sediment depths at Wilson Creek in September 2004 ..................................... 45

48 Water velocities and sediment depths at Bull Ditch in May 2004 .................................................... 46

49 Water velocities and sediment depths at Bull Ditch in June 2004 .................................................. 47

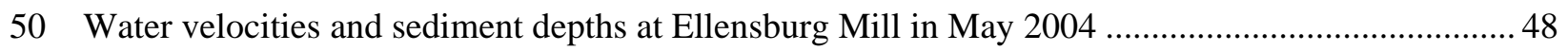

51 Water velocities and sediment depths at Ellensburg Mill in June 2004 .......................................... 48

52 Water velocities and sediment depths at Ellensburg Mill in September 2004................................. 49

53 Water velocities and sediment depths at Fruitvale in May 2004 .................................................. 50

54 Water velocities and sediment depths at Fruitvale in June 2004 ...................................................50

55 Water velocities and sediment depths at Fruitvale in September 2004 ......................................... 51

56 Water velocities and sediment depths at Naches-Selah in May 2004 .............................................. 52

57 Water velocities and sediment depths at Naches-Selah in June 2004 .............................................. 52

58 Water velocity and sediment depths at Naches-Selah in September 2004 ..................................... 53

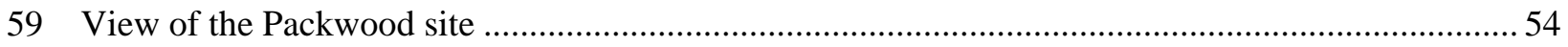

60 Water velocities and sediment depths at Packwood in May 2004 ....................................................54

61 Water velocities and sediment depths at Packwood in June 2004 .................................................5 55

62 Water velocities and sediment depths at Packwood in September 2004 .......................................... 55

63 View of Selah-Moxee from the canal side..................................................................................... 56

64 Water velocities and sediment depths at Selah-Moxee in May 2004 ............................................ 57

65 Water velocities and sediment depths at Selah-Moxee in June 2004 ............................................ 57

66 Water velocities and sediment depths at Selah-Moxee in September 2004..................................... 58

67 Water velocities and sediment depths at Union Gap in May 2004 ................................................. 59

68 Water velocities and sediment depths at Union Gap in July 2004...................................................59

69 Water velocities and sediment depths at Union Gap in September 2004 ........................................ 60

70 Water velocities and sediment depths at Yakima-Tieton in May 2004 ...........................................6 61

71 Water velocities and sediment depths at Yakima-Tieton in June 2004 ............................................6 61

72 Water velocities and sediment depths at Yakima-Tieton in September 2004 ................................ 62

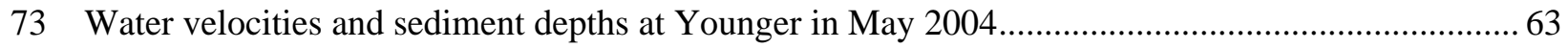

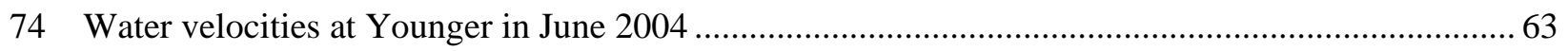

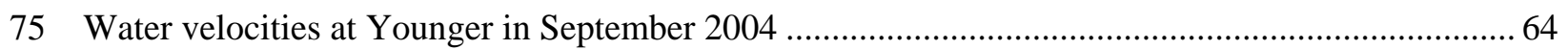

76 Water velocities and sediment depths at Gleed in May 2004 ........................................................65

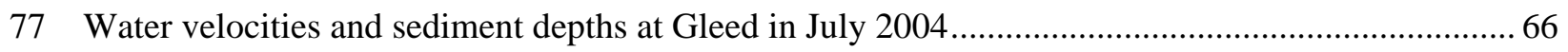

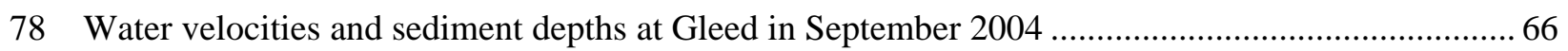




\section{Tables}

1 Agency responsible for the operation and maintenance of each fish screen facility .......................... 7

2 Mean sweep and approach velocities at Phase II fish screen facilities in the Yakima River Basin

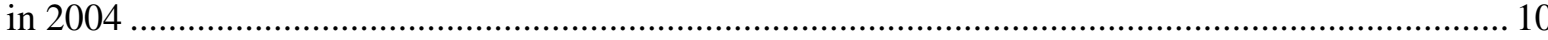

3 Annual percent of approach velocity measurements that were in excess of the NOAA Fisheries criteria of less than or equal to $0.4 \mathrm{ft} / \mathrm{s}$ for each screen site by year ............................................... 11

4 Summary of problem areas identified at Yakima River Basin Phase II screen sites in 1999 through 2004 


\subsection{Introduction}

Irrigation has played an important role in the development of the middle Columbia River Basin. Water has been diverted from western rivers since the mid 1850s to irrigate crops. During the 1920s, some of these diversions were equipped with fish protection devices, but it was not until the Mitchell Act of 1938 provided funding to protect fish that screening irrigation diversions and evaluating their effectiveness truly got under way (Bryant and Parkhurst 1950; McMichael et al. 2004).

In more recent history, the Bonneville Power Administration (BPA), under guidance from the Northwest Power Planning Council (NPPC), expanded screening efforts to protect and enhance fish populations. The NPPC Columbia River Fish and Wildlife Program lists effective screening of irrigation diversions as an essential element in its plan to restore declining steelhead and salmon runs (NPPC 1984, 1987, 1994, 2000).

Research on the effectiveness of fish screening devices initiated changes in design and operating procedures of screening facilities over the years. For example, maximum allowable screen size openings decreased as protecting fish at their earliest developmental stages became a concern. These and other new requirements for fish protection are developed by the National Oceanic and Atmospheric Administration Fisheries (NOAA Fisheries) (formerly National Marine Fisheries Service (NMFS)) and adopted by individual state agencies. In addition, the BPA has established a monitoring and evaluation program to ensure that new and updated screening facilities meet current fish protection standards.

As a part of the BPA monitoring and evaluation program, researchers from Pacific Northwest National Laboratory (PNNL) have conducted fish screen evaluations in the Yakima Basin since 1985. Initially, PNNL monitored Phase I screening facilities to determine whether fish that entered irrigation canals were guided back to the river safely (Neitzel et al. 1985, 1986, 1988, 1990a, 1990b). Additional studies examined water velocities in front of the screens to determine whether NOAA Fisheries criteria were being met (Abernethy et al. 1990). Two studies conducted at the PNNL Aquatics Laboratory in Richland, Washington, used modular drum screens constructed by the Washington Department of Fish and Wildlife (WDFW) to determine fish survival through submerged orifices and the relative effectiveness of two screen configurations at bypassing fish (Abernethy et al. 1996; Neitzel et al. 1997). The methods currently used for evaluating screening facilities were developed while conducting these earlier studies (Blanton et al. 1998, 1999; Chamness et al. 2001; Carter et al. 2002;

McMichael et al. 2004).

As the Phase II screening program continued, more sites were evaluated by PNNL for the BPA. In 2000, 21 Phase II sites were evaluated. The Powell-LaFortune and Wilson Creek sites were added in 2001, and Packwood and Selah-Moxee were added in 2004 for a total of 25 sites. The evaluations of these sites addressed two main questions:

1. Are screens designed, operated, and maintained to meet NOAA Fisheries criteria over a wide range of conditions?

2. Are screen sites effective at protecting fish from injury and from unnecessary migration delay? 


\subsection{Methods}

Twenty-five operating screen sites (Figure 1) in the Yakima, Naches, and Tieton river basins were evaluated three times between May 18 and September 27, 2004. PNNL researchers collected three types of data at each site, based on criteria set by the NOAA Fisheries for Phase II fish screen facilities. The types of data collected include water velocity measurements, underwater video, and general operational data (e.g., screen submergence, bypass conditions, fish presence).

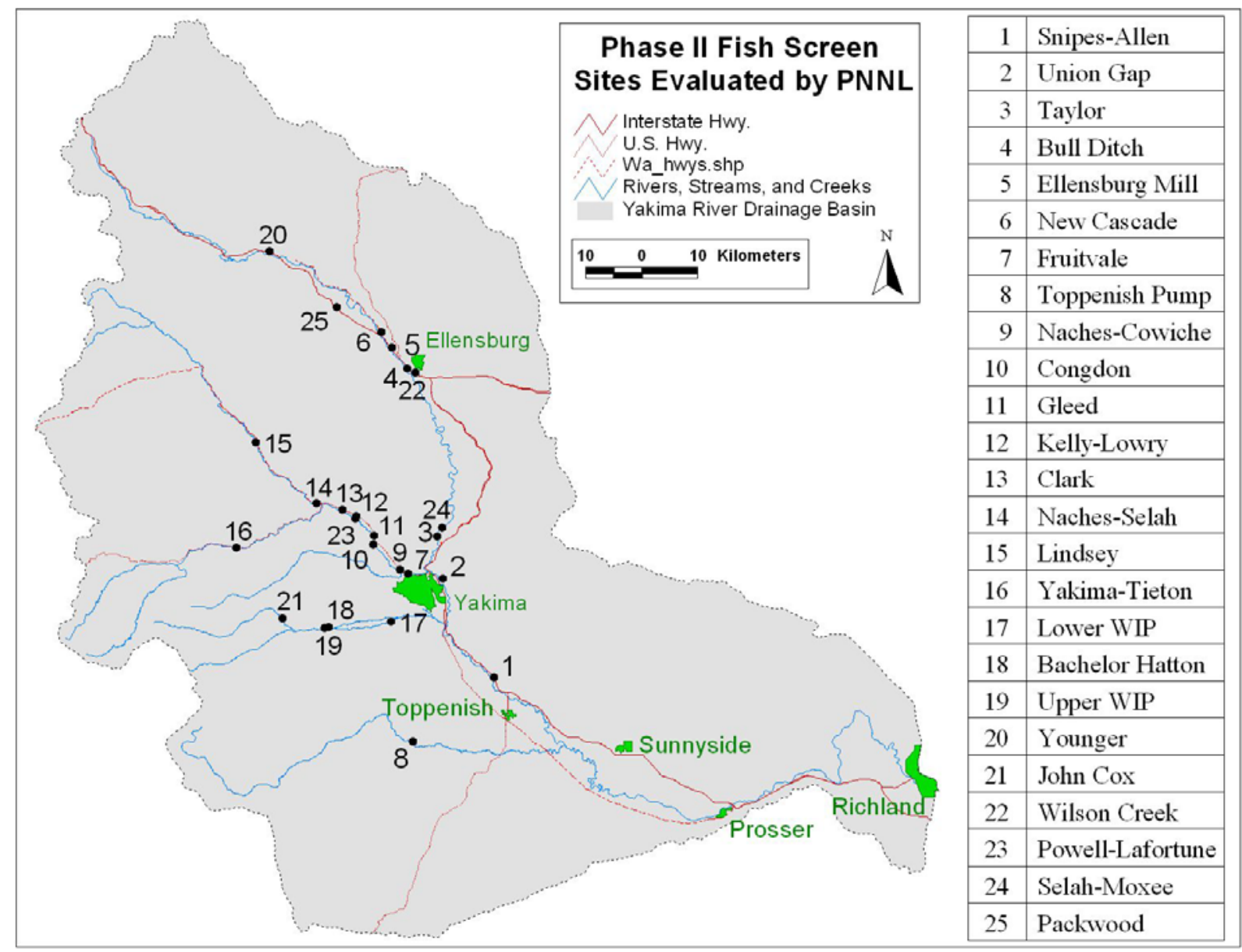

Figure 1. Yakima River Basin Phase II fish screen facilities

The NOAA Fisheries criteria for Phase II fish screen sites define velocity and general operational conditions that would be expected to promote safe fish passage through Phase II screen sites (NMFS 1995). These include the following:

- a uniform flow distribution over the screen surface to minimize approach velocity

- approach velocities less than or equal to $0.4 \mathrm{ft} / \mathrm{s}$

- sweep velocities that are greater than approach velocities

- a bypass flow greater than or equal to the maximum flow velocity vector resultant upstream of the screens (generally the sweep velocity) 
- a gradual and efficient acceleration of flow from the upstream end of the site into the bypass entrance to minimize delay of emigrating salmonids

- screen submergence between $65 \%$ and $85 \%$ for drum screen sites.

In addition, the NOAA Fisheries states that silt and debris accumulation should be kept to a minimum. For this report, the accumulation of silt and/or debris was considered excessive if the intersection of the seal and the screen was buried. Screen operators should try to achieve these criteria at all sites throughout the year. In this report, PNNL generally compared the field measurements of water velocity, underwater video, and general data collection results for each screen site to the NOAA Fisheries criteria. The following sections detail how each type of data was collected and Section 3 contains the results of the comparisons for each site.

\subsection{Water Velocity Measurements}

\subsubsection{Equipment}

With the exception of one site, water velocities in front of the screens and in the bypass were measured using a SonTek acoustic Doppler velocimeter (ADV). The ADV emits sound at $10 \mathrm{kHz}$. The frequency of the returning sound waves increases or decreases depending on whether the water is flowing towards or away from the ADV receiver. The difference between the emitted frequency and the received frequency is used to calculate the velocity of the water. The probe uses three receivers extending out at an angle from the transmitter to calculate the three-dimensional water velocity at a point $10 \mathrm{~cm}$ below the probe. Figure 2 shows the ADV probe on the left.

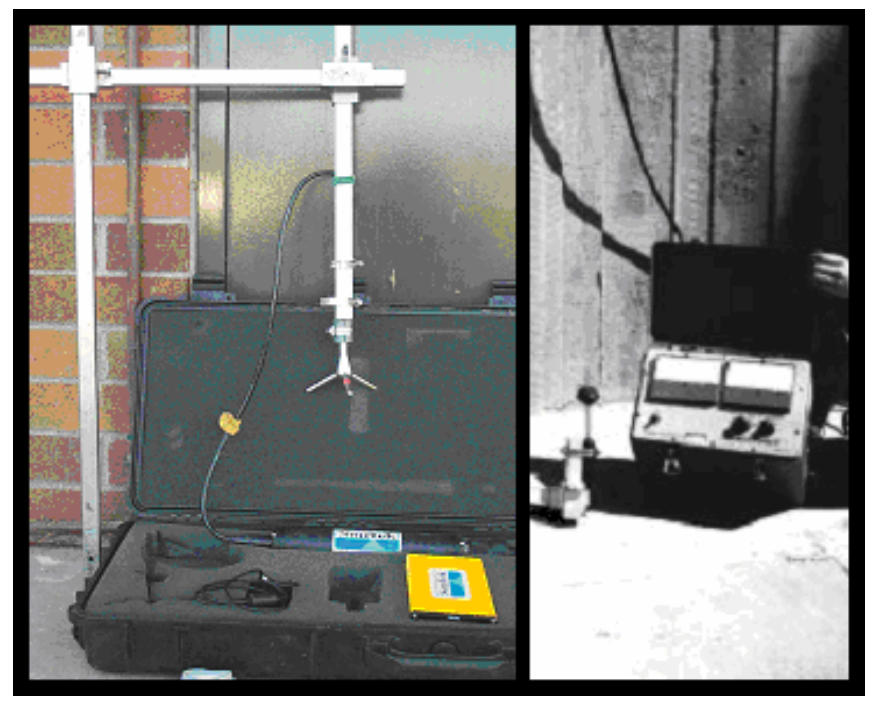

Figure 2. Acoustic Doppler velocimeter probe equipment (left) and the Marsh-McBirney 511® velocity meter (right).

The ADV probe was securely mounted to a horizontal metal arm that extended approximately 12 in. from a vertical pole. The probe was oriented into the current with the support assembly downstream or off to the side to minimize interference from the vertical pole when taking velocity readings. The length 
of the horizontal arm and its position on the vertical pole were adjustable. Velocities were typically recorded at each sampling point along the screen for $30 \mathrm{~s}$ at a rate of $2 \mathrm{~Hz}$ and stored in a computer file.

When the water was too shallow or there was too much vegetation or debris in the forebay, water velocities were measured using a Marsh-McBirney Model $511^{\circledR}$ electromagnetic water current meter. The meter uses a bi-directional probe that allows measurement of velocities in two directions (approach and sweep) simultaneously. Output was read visually from a panel gauge and recorded. Figure 2 shows the Marsh-McBirney probe on the right.

\subsubsection{Data Collection and Analyses}

Measurements of water velocity were taken at 2 to 5 evenly spaced points along the front of each screen and in the entrance to the bypass. The vertical pole was placed close to the front of the screen but not allowed to come in contact with the screen surface. The probe was positioned as close to the screen surface as possible, usually about 3 in., though it was impossible to get that close in some cases. The height that the probe was set from the bottom depended on the depth of water in the forebay. In cases where the forebay depth was less than 48 in., one set of measurements was taken at $0.6 \mathrm{x}$ depth from the surface. In cases where the forebay depth was greater than or equal to $48 \mathrm{in}$., measurements were taken at two depths ( $0.2 \mathrm{x}$ depth from the surface; $0.8 \mathrm{x}$ depth from the surface). All measurements were taken with the axes of the probe oriented to measure water flowing parallel (sweep) and perpendicular (approach) to the screen face.

Flow measurements were taken in front of every screen during site visits. Automatic cleaning brushes were usually turned off during velocity measurements, while drum screens were allowed to operate as normal during measuring. Average sweep and approach velocities were calculated for each visit to each site, and seasonal averages were calculated at the end of all surveys.

Graphical representations of velocity data include lines for mean sweep and approach velocity measurements, a reference line at $0.4 \mathrm{ft} / \mathrm{s}$ (which represents the NOAA Fisheries criteria for approach velocity), and a shaded area representing sediment accumulation in front of the screens as estimated with the support pole for the velocity probe, where the pole came to rest on the sill and in the bypass. The error bars on the velocity graphs represent the root mean-square (RMS) of the turbulent velocity fluctuations about the mean velocity. The RMS value is equal to the standard deviation of the individual velocity measurements.

\subsection{Underwater Video}

\subsubsection{Equipment}

An underwater video system was used to investigate screen seal condition and to monitor debris buildup and fish presence. The video system consisted of a digital deep-sea camera (DeepSea Power and Light, Inc., model MULTI-SEACAM 1050) connected to a digital video recorder (Sony Video Walkman, model GV-D800), which in turn was connected to a pair of video glasses (Olympus Eye-Trek, model FMD-200) (Figure 3). The advantage of this system was that it allowed the person operating the camera to see what they were recording while in the field, thus providing better video quality and a greater potential for problem identification. In addition the end product of this system was digital video which greatly improved the quality of still pictures captured from the video. 


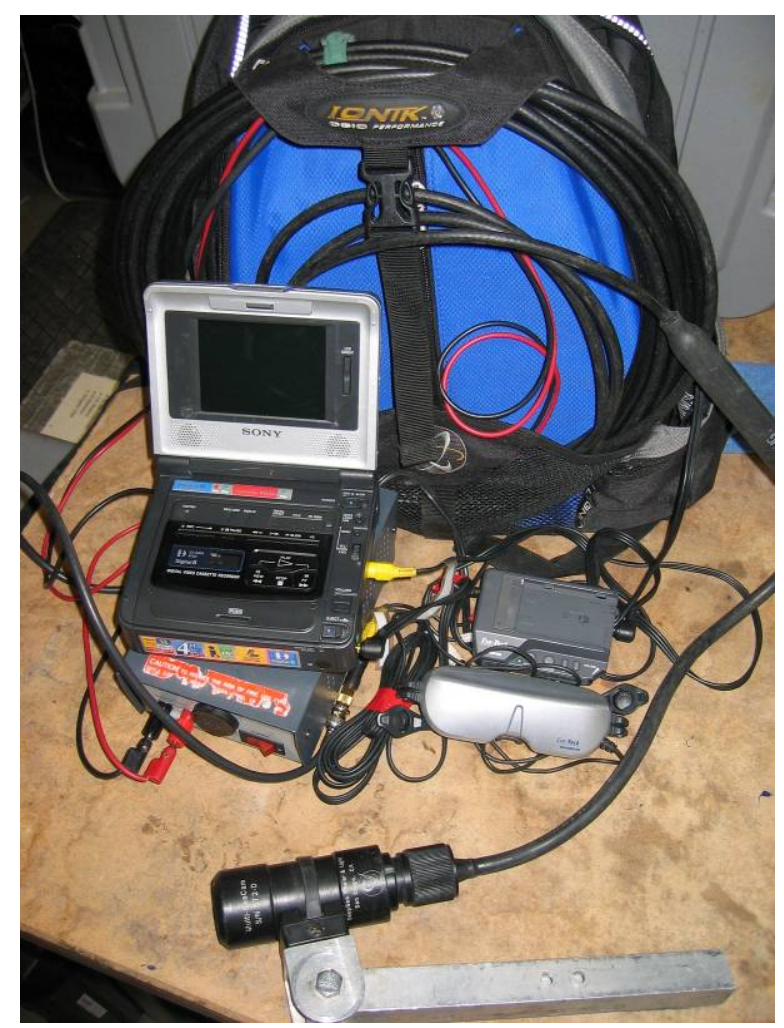

Figure 3. Underwater video system.

\subsubsection{Data Collection and Analyses}

The camera was securely mounted on a vertical pole and adjusted as needed at each site. The camera was usually angled slightly downward to look for potential gaps between the screen and the bottom seal. The camera was usually moved from upstream to downstream, following the side and bottom seal/screen interfaces. The bypass was also inspected, looking both upstream and downstream for signs of excessive debris or fish presence.

Written observations were made in the field when something of interest was seen with the camera (i.e., debris, gaps, and fish). All videos were later reviewed in detail, and images of interest were digitally captured using Optimas $^{\mathrm{TM}}$ software.

\subsection{General Data}

Additional data collected during each evaluation included the following:

- General site descriptions and photographs

- Screen and seal conditions

- Screen submergence levels

- Cleaning system operation and the incidence of head loss across the screen face

- Bypass flow conditions 
- Bypass outfall conditions

- Fish presence

- Observations of debris in the forebay, bypass, or outfall

- Presence or absence and condition of operator control aids such as water gauges and drum submergence marks on screen frames.

\subsection{Problem Tracking}

The problem identification and tracking program implemented in 2002 in response to comments from the Independent Scientific Review Panel provided increased accountability of operations and maintenance in cases when problems were fixable within the season. Agency response ranged from excellent to poor, but overall, the program seems to aid in serving fish passage and protection goals. When a problem such as a blocked bypass or excessive debris was identified at a screen site, the responsible agency (Table 1) was notified immediately by the field personnel and asked to notify PNNL when the issue was rectified or when a repair schedule was implemented. When PNNL received notice that a problem had been fixed, a team was sent to the site to reevaluate whether operating conditions met NOAA Fisheries criteria for safe fish passage. This protocol was also used during the 2003 and 2004 evaluations.

Table 1. Agency responsible for the operation and maintenance of each fish screen facility. WIP = Wapato Irrigation Project; USBR = U.S. Bureau of Reclamation; WDFW = Washington Department of Fish and Wildlife.

\begin{tabular}{||l|l||}
\hline \multicolumn{1}{|c|}{$\begin{array}{c}\text { Fish screen } \\
\text { facility }\end{array}$} & \multicolumn{1}{|c||}{$\begin{array}{c}\text { Responsible } \\
\text { agency }\end{array}$} \\
\hline \hline Bachelor-Hatton & USBR \\
\hline Bull Ditch & WDFW \\
\hline Clark & WDFW \\
\hline Congdon & WDFW \\
\hline Ellensburg Mill & WDFW \\
\hline Fruitvale & WDFW \\
\hline Gleed & WDFW \\
\hline John Cox & USBR \\
\hline Kelly-Lowry & WDFW \\
\hline Lindsey & WDFW \\
\hline Lower WIP & USBR \\
\hline Naches Cowiche & WDFW \\
\hline Naches Selah & WDFW \\
\hline \hline
\end{tabular}

\begin{tabular}{|l|l||}
\hline \multicolumn{1}{|c|}{$\begin{array}{c}\text { Fish screen } \\
\text { facility }\end{array}$} & \multicolumn{1}{|c||}{$\begin{array}{c}\text { Responsible } \\
\text { agency }\end{array}$} \\
\hline \hline New Cascade & WDFW \\
\hline Packwood & WDFW \\
\hline Powell-LaFortune & WDFW \\
\hline Selah-Moxee & WDFW \\
\hline Snipes-Allen & WDFW \\
\hline Taylor & WDFW \\
\hline Toppenish Pump & USBR \\
\hline Union Gap & WDFW \\
\hline Upper WIP & USBR \\
\hline Wilson Creek & WDFW \\
\hline Yakima-Tieton & USBR \\
\hline Younger & WDFW \\
\hline & \\
\hline
\end{tabular}




\subsection{Results and Discussion}

This section presents the overall results first and then describes each site in more detail. The site-by-site descriptions are organized into three groups: rotary drum screens, flat-plate screens, and vertical traveling screens.

\subsection{Overall Results}

\subsubsection{Water Velocity Measurements}

Although velocities often fluctuated widely from site to site and over time, average sweep velocities for the year typically exceeded average approach velocities for the year (Table 2). Only 3 out of 25 screen sites had mean approach velocities greater than mean sweep velocities in 2004. Season average approach velocities were all below the NOAA Fisheries criteria of less than or equal to $0.4 \mathrm{ft} / \mathrm{s}$. The number of sites with more than $10 \%$ of the measured approach velocities greater than $0.4 \mathrm{ft} / \mathrm{s}$ increased from 3 in 2003 to 6 in 2004, and the sites that did have average approach velocities greater than $0.4 \mathrm{ft} / \mathrm{s}$ tended to be the same sites that had exceeded the criteria over the past several years (Table 3 ). The number of sites that had bypass velocities that were slower than sweep velocities decreased from 14 in 2003 to 12 in 2004 (Table 4, Figure 4). 
Table 2. Mean sweep and approach velocities ( \pm standard deviation (S.D.)) at Phase II fish screen facilities in the Yakima River Basin in 2004. WIP = Wapato Irrigation Project.

\begin{tabular}{|c|c|c|c|c|}
\hline Screen Type & Site & $\begin{array}{c}\text { Mean Sweep } \\
\text { Velocity } \pm \text { S.D. }\end{array}$ & $\begin{array}{l}\text { Mean Approach } \\
\text { Velocity } \pm \text { S.D. }\end{array}$ & $\begin{array}{l}\text { Ratio of } \\
\text { Sweep to } \\
\text { Approach } \\
\end{array}$ \\
\hline \multirow{15}{*}{ Drum Screens } & Bachelor-Hatton & $0.20 \pm 0.45$ & $0.24 \pm 0.09$ & 0.83 \\
\hline & Clark & $0.13 \pm 0.15$ & $0.09 \pm 0.08$ & 1.44 \\
\hline & Congdon & $0.74 \pm 0.17$ & $0.31 \pm 0.11$ & 2.39 \\
\hline & \begin{tabular}{|l|} 
John Cox \\
\end{tabular} & $0.39 \pm 0.14$ & $0.09 \pm 0.10$ & 4.33 \\
\hline & Kelly-Lowry & $0.41 \pm 0.14$ & $0.22 \pm 0.10$ & 1.86 \\
\hline & Lindsey & $0.26 \pm 0.08$ & $0.12 \pm 0.06$ & 2.17 \\
\hline & Lower WIP & $0.07 \pm 0.09$ & $0.16 \pm 0.10$ & 0.44 \\
\hline & Naches-Cowiche & $0.91 \pm 0.39$ & $0.16 \pm 0.14$ & 5.69 \\
\hline & New Cascade & $0.58 \pm 0.17$ & $0.18 \pm 0.09$ & 3.22 \\
\hline & Powell-LaFortune & $0.70 \pm 0.14$ & $0.09 \pm 0.09$ & 7.78 \\
\hline & Snipes-Allen & $0.27 \pm 0.11$ & $0.17 \pm 0.04$ & 1.59 \\
\hline & Taylor & $0.24 \pm 0.13$ & $0.20 \pm 0.05$ & 1.20 \\
\hline & Toppenish Pump & $0.98 \pm 0.51$ & $0.19 \pm 0.16$ & 5.16 \\
\hline & Upper WIP & $0.65 \pm 0.27$ & $0.17 \pm 0.06$ & 3.82 \\
\hline & Wilson Creek & $0.46 \pm 0.09$ & $0.18 \pm 0.06$ & 2.56 \\
\hline \multirow{9}{*}{$\begin{array}{l}\text { Vertical plate } \\
\text { screens }\end{array}$} & Bull Ditch & $0.42 \pm 0.53$ & $0.10 \pm 0.13$ & 4.20 \\
\hline & Ellensburg Mill & $0.17 \pm 0.10$ & $0.07 \pm 0.04$ & 2.43 \\
\hline & Fruitvale & $0.67 \pm 0.20$ & $0.17 \pm 0.08$ & 3.94 \\
\hline & Naches-Selah & $1.18 \pm 0.29$ & $0.38 \pm 0.18$ & 3.11 \\
\hline & Packwood & $0.18 \pm 0.14$ & $0.07 \pm 0.06$ & 2.57 \\
\hline & Selah-Moxee & $1.11 \pm 0.32$ & $0.15 \pm 0.13$ & 7.40 \\
\hline & Union Gap & $1.20 \pm 0.22$ & $0.34 \pm 0.13$ & 3.53 \\
\hline & Yakima-Tieton & $1.65 \pm 0.52$ & $0.16 \pm 0.20$ & 10.31 \\
\hline & Younger & $1.08 \pm 0.41$ & $0.25 \pm 0.12$ & 4.32 \\
\hline $\begin{array}{l}\text { Vertical } \\
\text { travelling } \\
\text { screen } \\
\end{array}$ & Gleed & $0.21 \pm 0.68$ & $0.31 \pm 0.37$ & 0.68 \\
\hline
\end{tabular}


Table 3. Annual percent of approach velocity measurements that were in excess of the NOAA Fisheries criteria of less than or equal to $0.4 \mathrm{ft} / \mathrm{s}$ for each screen site by year. The shaded numbers represent sites for which greater than $10 \%$ of the approach velocities for the year were in excess of $0.4 \mathrm{ft} / \mathrm{s}$.

\begin{tabular}{|c|c|c|c|c|c|c|c|c|}
\hline \multirow{2}{*}{$\begin{array}{l}\text { Screen } \\
\text { Type }\end{array}$} & \multirow[b]{2}{*}{ Screen Site } & \multicolumn{7}{|c|}{$\begin{array}{c}\text { Percent of Approach Velocity Measurements } \geq 0.4 \\
\text { ft } / \mathbf{s}\end{array}$} \\
\hline & & 1998 & 1999 & 2000 & $2001(d)$ & 2002 & 2003 & 2004 \\
\hline \multirow{15}{*}{$\begin{array}{l}\text { Drum } \\
\text { Screens }\end{array}$} & Bachelor-Hatton & 34.1 & 0.0 & 15.4 & (e) & 2.5 & 1.7 & 10.0 \\
\hline & Clark & 0.0 & (a) & 0.0 & 0.0 & 0.0 & 0.0 & 0.0 \\
\hline & Congdon & 4.4 & 8.3 & 7.1 & 13.3 & 11.1 & 6.7 & 22.2 \\
\hline & John Cox & (c) & (c) & 39.3 & (e) & 27.5 & 34.8 & 38.9 \\
\hline & Kelly-Lowry & 0.0 & 0.0 & 0.0 & 20.0 & 0.0 & 0.0 & 3.7 \\
\hline & Lindsey & 0.0 & 0.0 & 0.0 & 0.0 & 0.0 & 0.0 & 0.0 \\
\hline & Lower WIP & (b) & 0.0 & 0.0 & (e) & 38.9 & 5.6 & 0.0 \\
\hline & Naches-Cowiche & 0.0 & 12.5 & 2.6 & 5.0 & 1.7 & 0.0 & 5.0 \\
\hline & New Cascade & (a) & 0.0 & 1.4 & (e) & 2.5 & 0.0 & 1.7 \\
\hline & Powell-LaFortune & (c) & (c) & (c) & 0.0 & 0.0 & 1.7 & 0.0 \\
\hline & Snipes-Allen & 0.0 & 0.0 & 0.0 & 0.0 & 0.0 & 0.0 & 0.0 \\
\hline & Taylor & 0.0 & 0.0 & 0.0 & 0.0 & 0.0 & 0.0 & 0.0 \\
\hline & Toppenish Pump & 60.0 & 25.4 & 9.4 & 3.3 & 31.1 & 5.8 & 9.2 \\
\hline & Upper WIP & 9.4 & 2.5 & 3.3 & (e) & 5.0 & 8.3 & 0.0 \\
\hline & Wilson Creek & (c) & (c) & (c) & 0.0 & 4.4 & 0.0 & 0.0 \\
\hline \multirow{9}{*}{$\begin{array}{l}\text { Vertical } \\
\text { plate } \\
\text { screens }\end{array}$} & Bull Ditch & 2.9 & 14.7 & 22.2 & 0.0 & 12.5 & 4.9 & 3.7 \\
\hline & Ellensburg Mill & 0.0 & 33.3 & 25.9 & 0.0 & 0.0 & 0.0 & 0.0 \\
\hline & Fruitvale & (a) & 0.0 & 17.5 & 0.0 & 5.6 & 0.0 & 0.0 \\
\hline & Naches-Selah & 2.8 & 27.8 & 28.7 & 8.3 & 29.6 & 20.4 & 46.3 \\
\hline & Packwood & (c) & (c) & (c) & (c) & (c) & (c) & 0.0 \\
\hline & Selah-Moxee & (c) & (c) & (c) & (c) & (c) & (c) & 5.6 \\
\hline & Union Gap & 5.0 & 22.9 & 12.5 & 4.2 & 2.8 & 9.7 & 43.1 \\
\hline & Yakima-Tieton & 5.2 & 2.1 & 1.4 & 2.1 & 14.4 & 2.8 & 18.1 \\
\hline & Younger & (c) & 0.0 & 8.3 & 0.0 & 33.3 & 0.0 & 5.6 \\
\hline $\begin{array}{l}\text { Vertical } \\
\text { travelling } \\
\text { screen }\end{array}$ & Gleed & (a) & 14.3 & 17.5 & 0.0 & 17.4 & 28.8 & 35.0 \\
\hline \multicolumn{9}{|c|}{$\begin{array}{l}\text { (a) No data; electrical interference prevented velocity measurements. } \\
\text { (b) No data; flooded in May and nearly dry by July } 1998 . \\
\text { (c) Not sampled. } \\
\text { (d) Based on September data only, except Snipes-Allen, Taylor, Toppenish Pump, Naches } \\
\text { Selah, and Union Gap. } \\
\text { (e) No data; equipment problems in May and June, and site was dry in September. }\end{array}$} \\
\hline
\end{tabular}


Table 4. Summary of problem areas identified at Yakima River Basin Phase II screen sites in 1999 through 2004. The different symbols represent different years. John Cox was not evaluated in 1999, Powell-LaFortune and Wilson Creek were not evaluated in 1999 or 2000, and Packwood and Naches-Selah were only evaluated in 2004.

\begin{tabular}{|c|c|c|c|c|c|c|c|c|c|c|c|c|c|c|c|c|c|c|c|c|c|c|c|c|c|c|c|c|c|c|c|c|c|c|c|c|c|}
\hline \multirow{2}{*}{$\begin{array}{l}\text { Screen } \\
\text { type }\end{array}$} & \multirow[b]{2}{*}{ Site } & \multicolumn{6}{|c|}{$\begin{array}{c}\geq 10 \% \text { of Approach Velocities } \\
>0.4 \mathrm{ft} / \mathrm{s}\end{array}$} & \multicolumn{6}{|c|}{\begin{tabular}{|c} 
Bypass Velocities Slower than \\
Sweep Velocities at Least \\
Once
\end{tabular}} & \multicolumn{6}{|c|}{ Damaged Screen or Seal } & \multicolumn{6}{|c|}{$\begin{array}{l}\text { Submergence Outside } \\
\text { Criteria at Least Once }\end{array}$} & \multicolumn{6}{|c|}{$\begin{array}{l}\text { Excessive Silt or Debris } \\
\text { at Least Once }\end{array}$} & \multicolumn{6}{|c|}{$\begin{array}{c}\text { Bypass Outfall }<1 \mathrm{ft} \text { at } \\
\text { Least Once }\end{array}$} \\
\hline & & '99 & 100 & $\mathbf{\prime}^{\mathbf{a}, \mathrm{b}}$ & '02 & '03 & \begin{tabular}{|l|}
04 \\
\end{tabular} & 99 & 100 & '01 ${ }^{\text {a,b }}$ & \begin{tabular}{|l|} 
\\
\end{tabular} & \begin{tabular}{|l|l}
03 \\
\end{tabular} & '04 & '99 & '00 & '01' & '02 & '03 & '04 & '99 & '00 & '01' & '02 & '03 & '04 & 199 & '00 & '01 & '02 & '03 & '04 & '99 & 100 & '01' & '02 & '03 & '04 \\
\hline \multirow{15}{*}{$\begin{array}{l}\text { Drum } \\
\text { Screens }\end{array}$} & Bachelor-Hatton & & $\nabla$ & & & & $\star$ & & $\nabla$ & & & & & -1 & & * & & & & 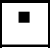 & $\nabla$ & & $\Delta$ & $*$ & $\star$ & & $\nabla$ & & $A$ & $*$ & $\star$ & & & & & & \\
\hline & Clark & & & & & & & & & & & & & & & & & & & & $\nabla$ & $*$ & & & & & & & & & & & & & & $*$ & \\
\hline & \begin{tabular}{|l|} 
Congdon \\
\end{tabular} & & $\nabla$ & $*$ & $\triangle$ & & $\star$ & & & & & $*$ & $\star$ & & & & & & & - & & $*$ & & & $\star$ & & & & & & & & & & & & \\
\hline & \begin{tabular}{|l|} 
John Cox \\
\end{tabular} & & $\nabla$ & & $A$ & $*$ & $\star$ & & & & $\triangle$ & $*$ & $\star$ & & & $*$ & & $*$ & & & $\nabla$ & & & & & & & & & $*$ & $\star$ & & $\nabla$ & $*$ & & $*$ & $\star$ \\
\hline & Kelly-Lowry & & & $*$ & & & & & & $*$ & $A$ & $*$ & $\star$ & & & & & & & & $\nabla$ & $*$ & & & & - & $\nabla$ & $*$ & $A$ & $*$ & $\star$ & & & & & & \\
\hline & Lindsey & & & & & & & & & & & $*$ & & - & & & & & & & & $*$ & & & $\star$ & & & & & & & & & & & & \\
\hline & Lower WIP & & & & $\Delta$ & & & - & & & $\triangle$ & $*$ & $\star$ & & & & & $*$ & & - & & & & $*$ & $\star$ & - & & $*$ & $\Delta$ & $*$ & $\star$ & & & & & & \\
\hline & \begin{tabular}{|l} 
Naches-Cowiche \\
\end{tabular} & - & & & & & & & & * & & $\%$ & $\star$ & & & & & & & & & & & & 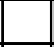 & & & & $A$ & $*$ & & & & & & & \\
\hline & \begin{tabular}{|l|} 
New Cascade \\
\end{tabular} & & & & & & & & & & & $*$ & $\star$ & - & & $*$ & $\triangle$ & & & - & $\nabla$ & $*$ & & $*$ & $\star$ & & $\nabla$ & $*$ & A & & & & & & & $*$ & $\star$ \\
\hline & Powell-Lafortune & & & & & & & & & $*$ & $\Delta$ & $\%$ & & & & & & & & & & $*$ & $\triangle$ & & $\star$ & & & & A & $*$ & $\star$ & & & & & $*$ & \\
\hline & \begin{tabular}{|l|} 
Snipes-Allen \\
\end{tabular} & & & & & & & & $\nabla$ & $*$ & $A$ & $*$ & $\star$ & & & & & & & - & & & & & & & & & & $*$ & & & & & & & \\
\hline & Taylor & & & & & & & & & & & $*$ & $\star$ & & & & & & & & & $*$ & & 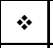 & $\star$ & & & $*$ & $\Delta$ & $*$ & $\star$ & & & & & & \\
\hline & \begin{tabular}{|l|} 
Toppenish Pump \\
\end{tabular} & - & & & $\Delta$ & & & & & & & & & - & & & & $*$ & & & $\nabla$ & $*$ & $\Delta$ & & & - & $\nabla$ & $*$ & $A$ & $*$ & & & & & & & \\
\hline & \begin{tabular}{|l|} 
Upper WIP \\
\end{tabular} & & & & & & & & & & $A$ & & $\star$ & - & & & $\Delta$ & $*$ & $\star$ & & & & & $*$ & $\star$ & - & $\nabla$ & & $\Delta$ & $*$ & $\star$ & & & $*$ & & & \\
\hline & Wilson Creek & & & & & & & & & $*$ & $A$ & $*$ & $\star$ & & & & $A$ & & & & & $*$ & & & & & & $*$ & & & & & & & & & \\
\hline \multirow{9}{*}{$\begin{array}{l}\text { Vertical } \\
\text { Plate } \\
\text { Screens }\end{array}$} & Bull Ditch & - & & & $\triangle$ & & & & & & & & & & & & & & & & & & & & & & & $*$ & . & & $\star$ & & & & & & \\
\hline & Ellensburg Mill & - & $\nabla$ & & & & & - & & $*$ & & & & - & & $*$ & & & & & & & & & & - & & * & $A$ & $*$ & & & & & & & \\
\hline & Fruitvale & & $\nabla$ & & & & & & & & & $*$ & & & & & & & & - & & $*$ & & & & & & & & & & & & & & & \\
\hline & Naches-Selah & - & $\nabla$ & & $\triangle$ & $*$ & $\star$ & & $\nabla$ & $*$ & $\triangle$ & $*$ & & - & & & & & & & & & & & & & & & $A$ & & & & & $*$ & & $*$ & $\star$ \\
\hline & Packwood & & & & & & & & & & & & & & & & & & & & & & & & & & & & & & & & & & & & \\
\hline & Selah-Moxee & & & & & & & & & & & & & & & & & & & & & & & & & & & & & & & & & & & & \\
\hline & Union Gap & - & $\nabla$ & & & & $\star$ & - & & $*$ & $\triangle$ & $*$ & $\star$ & - & & & & & & & & & & & & & & & $\Delta$ & & & & & & & & \\
\hline & Yakima-Tieton & & & & $A$ & & $\star$ & & $\nabla$ & $*$ & & & $\star$ & & & $*$ & $\Delta$ & & & & & & & & & & & & & & & & & $*$ & & & $\star$ \\
\hline & \begin{tabular}{|l|} 
Younger \\
\end{tabular} & & & & $A$ & & & & & & & & & & & $*$ & & & & & & & & & & & & & & & & & & & & & \\
\hline \begin{tabular}{|l|} 
Vertical \\
traveling \\
screens \\
\end{tabular} & Gleed & - & $\nabla$ & & $\Delta$ & $*$ & $\star$ & & & & & & & & & & & & & & & & & & & - & & & & & & & & & & & \\
\hline
\end{tabular}




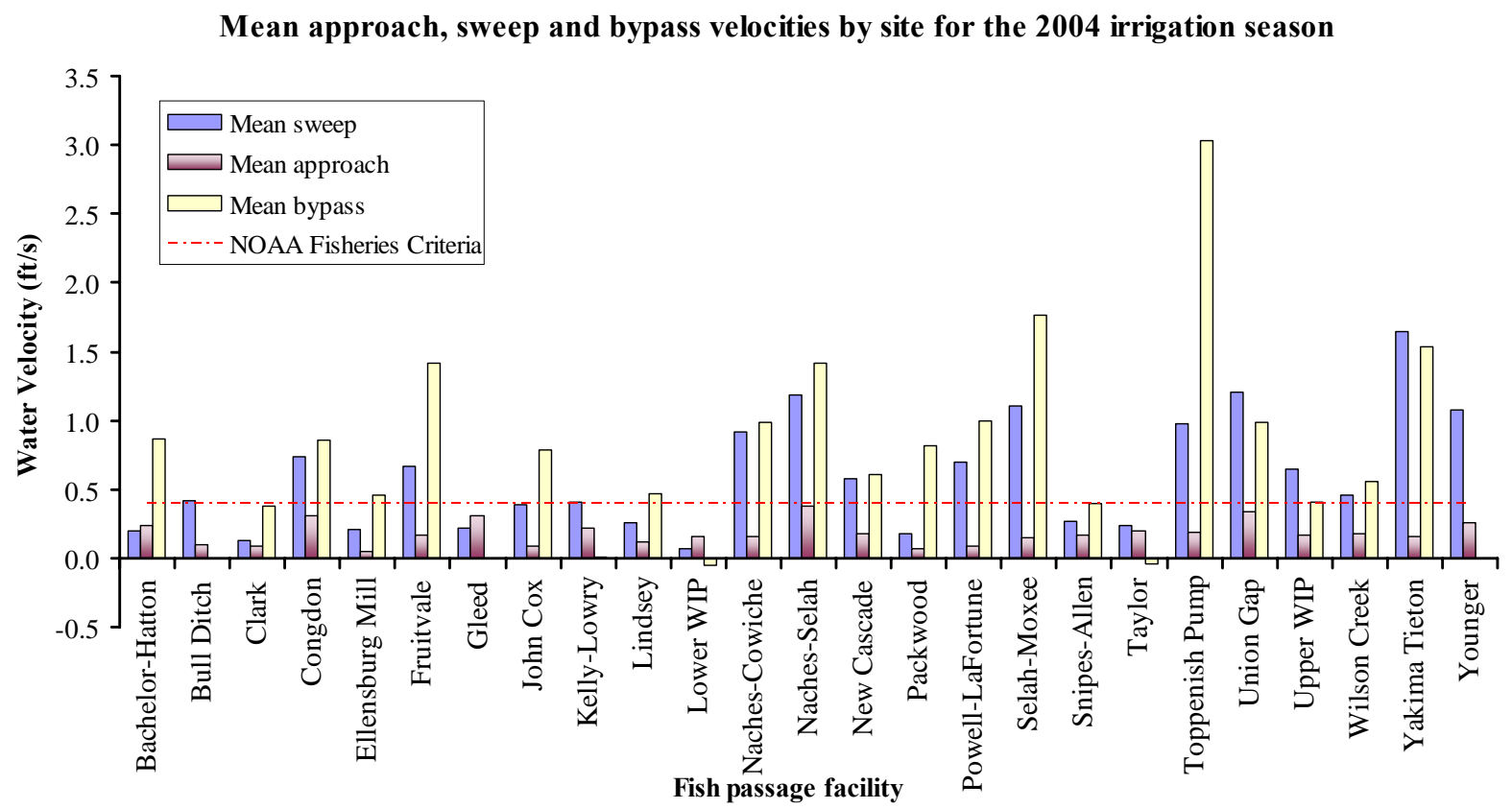

Figure 4. Mean approach, sweep, and bypass velocities at Phase II fish screen facilities in the Yakima River Basin in 2004 shown against a reference line for the NOAA Fisheries approach criteria (less than or equal to $0.4 \mathrm{ft} / \mathrm{s}$ ).

Overall, 87\% of all approach velocity measurements met the NOAA Fisheries approach criteria of less than or equal to $0.4 \mathrm{ft} / \mathrm{s}$ (7\% less than in 2003). This was much lower than the $97 \%$ reported in 2001; however, 2001 was an exceptionally low-water year, and many sites did not have enough water to meet other criteria, such as submergence and bypass flow. Similar conditions existed in 2004, with many sites unable to meet bypass flow requirements. Areas of the screen (i.e., top, bottom, upstream, downstream) that exceeded approach criteria were dependent on factors at the individual sites.

Water velocities at each site were often highly variable, both spatially and temporally. Flows were typically not uniform over screen surfaces. Often, there were distinct differences between top and bottom approach velocity values, but there was no obvious pattern associated with those differences. To standardize problem reporting, PNNL calculated average velocities for each screen site for each evaluation and for the whole season. Sites with $10 \%$ or more approach velocities greater than $0.4 \mathrm{ft} / \mathrm{s}$ per evaluation were considered to be in violation of NOAA Fisheries criteria. In 2004, 7 sites fell into this category (Table 4). Also, considering season averages, sweep velocity was greater than approach velocity at all except 3 sites (Table 2, Figure 4). The same three sites also had negative sweeping velocities, i.e., moving from downstream to upstream across one or more screens. However, 12 of the 25 sites had bypass velocities that were slower than the average sweep (Table 4, Figure 4). This is similar to patterns observed in 2003 and is an area of concern because slow bypass velocities relative to sweep velocities could result in migration delay.

\subsubsection{Underwater Video}

Underwater video was used to inspect the conditions of the seals, to look for gaps between the seals and the screens that could allow small fish to pass through the site into the canal or be entrained or 
otherwise harmed, to record fish presence at the sites, and to monitor and document sediment and debris accumulation in front of the screens. The latter is important because debris can severely decrease seal life, cause drag on screen motors, and provide cover for fish predator species. Eight sites were recorded as having excessive silt or debris at least once during 2004, three less than in 2003 (Table 4). Seven of these were drum screen sites.

Most screens were properly sealed to prevent fish entrainment and injury. In general, visible screen seals were in good condition. Bottom frame seals were sometimes buried in debris or aquatic plants and could not be evaluated. All drum screen seals that were classified as in "good condition" were tight against the screen and not cracked, warped, or punctured in any way. Many of the drum screen sites had expanding foam insulation placed between the concrete sides of the facility and the metal "cheeks" of the drum frame. This blocked off an area that could have entrained small fish, although they could not normally have moved into the aftbay (canal) through this route. Flat-plate screen seals were generally in good condition with the exception of some panels showing loose or missing caulking (e.g., Yakima-Tieton and Fruitvale). Many of the flat-plate sites with loose or missing caulking were in poor condition in previous years and have never been improved. These sites were not identified under the problem-tracking protocol because these are problems that would not be expected to cause delay or injury to migrating fish as long as the site meets NOAA Fisheries criteria for approach velocity.

Two potential problems were identified in 2004, an improvement over 2003. Two sites (Upper WIP and Yakima-Tieton) had loose or damaged seals that might have allowed fish to be entrained or caused physical damage to them (Table 4). The problem at Upper WIP was not new; it had been identified in previous years but we processed it through the problem-tracking protocol anyway because it is a problem that could be taken care of while the site is shut down for the winter. Yakima-Tieton has had damaged seals for the past several years, but this is the first time that we have noticed a hole that could potentially allow fish to pass.

\subsubsection{General Data}

In 2003, most sites were operating in a manner that would be expected to provide safe passage for juvenile salmonids. Some sites, such as Lindsey, were well maintained, well designed, and rarely exceeded criteria; while others, such as Gleed, have had various problems over the past several years.

Automated cleaning brushes generally functioned properly; chains and other moving parts were well greased and operative. The WDFW's screen shop staff were generally prompt in repairing and/or cleaning screens. The percent of sites with excessive debris problems had been on the rise over the past several years, and began to improve in 2003 with $48 \%$ of sites having accumulated an excessive amount of sediment or debris. This improvement trend continued in 2004 with 32\% of sites having accumulated excessive sediment or debris (Table 4). The buildup of sediment and debris is a concern because it can create habitat for predators and cause mechanical brushes or drums to become less effective or even cease functioning.

\subsubsection{Screen Submergence Levels}

Phase II rotary drum screens are designed to be operated at submergence levels between $65 \%$ and 85\%. At higher submergence levels, fish may roll over the top of the screen and enter the canal. Lower 
submergence levels can prevent the screen from efficiently removing debris from the forebay area. In 2004, 20\% of drum screens were outside submergence criteria at least once, down from 33\% in 2003.

Flat-plate screen sites do not have the same roll over and debris removal issues to contend with as rotary drum screens. However, should a flat-plate screen become completely submerged, fish can freely enter the irrigation canals by swimming over the top of the screen. Therefore, beginning in 2001, flat-plate screen sites were marked in Table 4 only if screens were completely submerged at any point during the irrigation season. Total screen submergence at flat-plate sites was not observed during our surveys nor was it mentioned in any operator logbooks in 2004.

\subsubsection{Bypass Outfall Conditions}

The NOAA Fisheries established a number of guidelines and criteria concerning bypass conduit design and outfall conditions (NMFS 1995). These criteria state that, "for diversions 25 cfs and greater, the required pipe diameter shall be greater than or equal to 24 inches and that the minimum depth of open-channel flow in the bypass conduit shall be greater than or equal to 9 inches, unless otherwise approved by the NMFS.” Pipe diameter criteria exist primarily to minimize debris clogging and sediment deposition and to facilitate cleaning. For screens with a diversion flow of less than 25 cubic feet per second (cfs), the requirements are a 10-in.-diameter pipe and a minimum allowable water depth in the pipe of 1.8 in. All screens with bypasses that were evaluated with the exception of Bull Ditch, Clark, John Cox, Lindsey, Lower Wapato Irrigation Project (WIP), Packwood, Taylor, Wilson Creek, and Younger are designed and built for diversion flows greater than $25 \mathrm{cfs}$. Many sites had bypass pipes with diameters much smaller than the NOAA Fisheries criteria. However, all sites appeared to meet the minimum requirements for in-pipe water depth in 2004. More often, an area of concern is the depth of water just downstream of the outfall. In 2004, four sites had less than $1 \mathrm{ft}$ of water below the outfall. This is a potential problem because it creates easy access for avian predators. Where possible, sites should be modified so that the outfall flows into a large enough body of water to prevent predation.

\subsubsection{Operator Control Aids}

Visual operator control aids, while not required, are extremely useful for the maintenance and operations personnel who inspect the sites. Operator aids complement the operating criteria and help "flag" operational or procedural problems. Operator aids include marks indicating submergence level on drum screen frames; water depth or elevation gauges in the forebay, aftbay, and irrigation canal; and marks indicating how far headgate, bypass weir, or canal intakes are open. Providing highly visible indicators of screen system operation as it relates to NOAA Fisheries criteria or to proper water diversion to the canal can save time and reduce incidences of operator error that may result in fish impingement, entrainment, or stranding at a site.

Most sites were equipped with gauges measuring elevation or water depth, although gauges were not always present both in front of and behind the screens. Drum screen submergence marks were present at

most sites but were often difficult to read due to weathering, and later in the season because of the growth of algae. As a result of this study, PNNL recommends regular cleaning and repainting of these marks to facilitate operator adjustments and evaluation. 


\subsection{Rotary Drum Screens}

\section{Bachelor-Hatton}

The Bachelor-Hatton site was evaluated May 26, 2004; June 23, 2004; and September 21, 2004, although no water was present at the site in September. In May and June, 80\% and 100\% of approach velocities met NOAA Fisheries criteria, respectively (Figures 5 and 6). Jim Rice was notified concerning the high approach velocities on May 26. We were not notified of any changes, and followed up during our normally scheduled evaluation in June. In May, sweep velocity generally increased from the upstream screens to the downstream end of the site, and the bypass velocity was greater than the average sweep velocity. In June, the sweep velocity increased very slightly from the upstream screens to the downstream end of the site, but the bypass velocity was less than the average sweep velocity. The sweep velocity in front of screen 1 was generally negative or flowing upstream. Because of the design of the site, water entering through the headgates normally contacts the screens somewhere around screen 2 and then separates into two components, one that moves downstream towards the bypass and another that moves upstream, potentially confusing fish.

No operator control aids such as submergence marks painted on the screen frames or gauges for measuring water depth have been installed at this site. However, submergence calculations revealed that the site was slightly above criteria in May, and met criteria in June (87\% and 74\% submergence, respectively). The condition of the screens and seals was good throughout the season, though the gaps between the metal "cheeks" of the drum screen frames and concrete of the forebay were only filled in places, and some of the gaps are quite large.

Video surveys in May and June and a visual inspection in September showed that the visible portions of the screen seals were in good condition. There was some sediment accumulation in front of screen 4 in May and June which obscured our view of the bottom seal. Increasing the sweeping velocities at the downstream end of the site may help to alleviate sediment accumulation. An excessive amount of twigs and other debris were present in front of screen 4 and in the bypass during all surveys. Bypass conditions were good in May although in June the water depth in the channel between the outfall and the stream was less than $1 \mathrm{ft}$. This channel may need to be deepened in order for water levels to stay consistently deep enough to prevent predation. 
Bachelor-Hatton - May 26, 2004

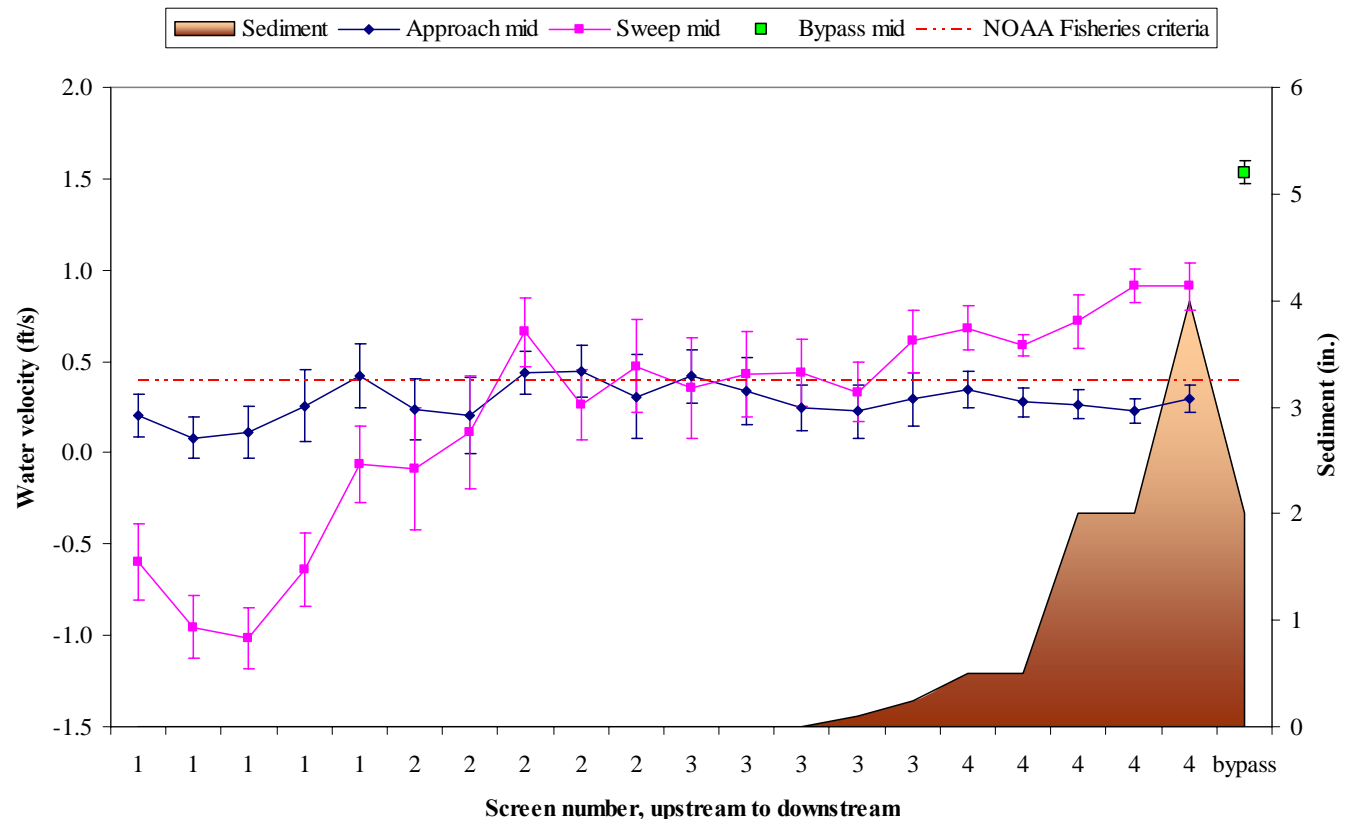

Figure 5. Water velocities and sediment accumulation at Bachelor-Hatton in May 2004. Error bars ( \pm the root-mean-squared (RMS)) represent turbulence at each point.

Bachelor-Hatton - June 23, 2004

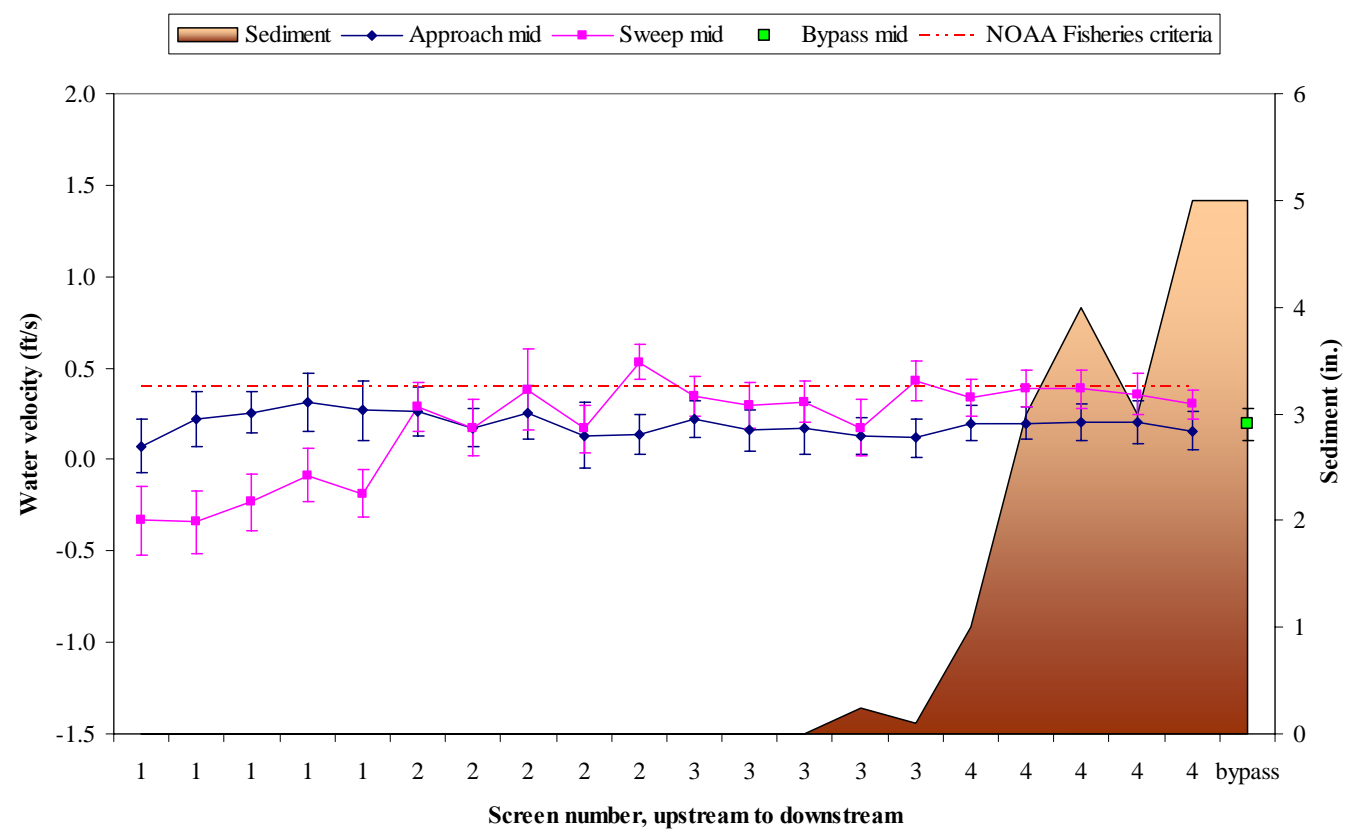

Figure 6. Water velocities and sediment accumulations at Bachelor-Hatton in June 2004. Error bars show turbulence ( \pm the root-mean-squared (RMS)) at each point. 


\section{Clark}

The Clark screening facility was evaluated on May 21, 2004; July 1, 2004; and September 23, 2004. Approach velocities were always less than $0.4 \mathrm{ft} / \mathrm{s}$, and sweep velocities were higher than approach velocities in May and September (Figures 7 through 9). The water velocity in the bypass was always greater than the average sweep velocity, though there was not a clear increase in sweep velocity from upstream to downstream within the site.

The condition of the screen and seals was good throughout all surveys. No sediment was present in front of the screens in May and September, and little was present in June. Screen submergence met criteria during all site visits, at $81 \%$ in May and June and 79\% in September. No water was observed flowing over the headgates during any survey, although in May the water was backed up behind the headgates and was beginning to pool on the walkway (Figure 10). Water always flowed freely over the weir and through the bypass outfall.

Clark - May 21, 2004

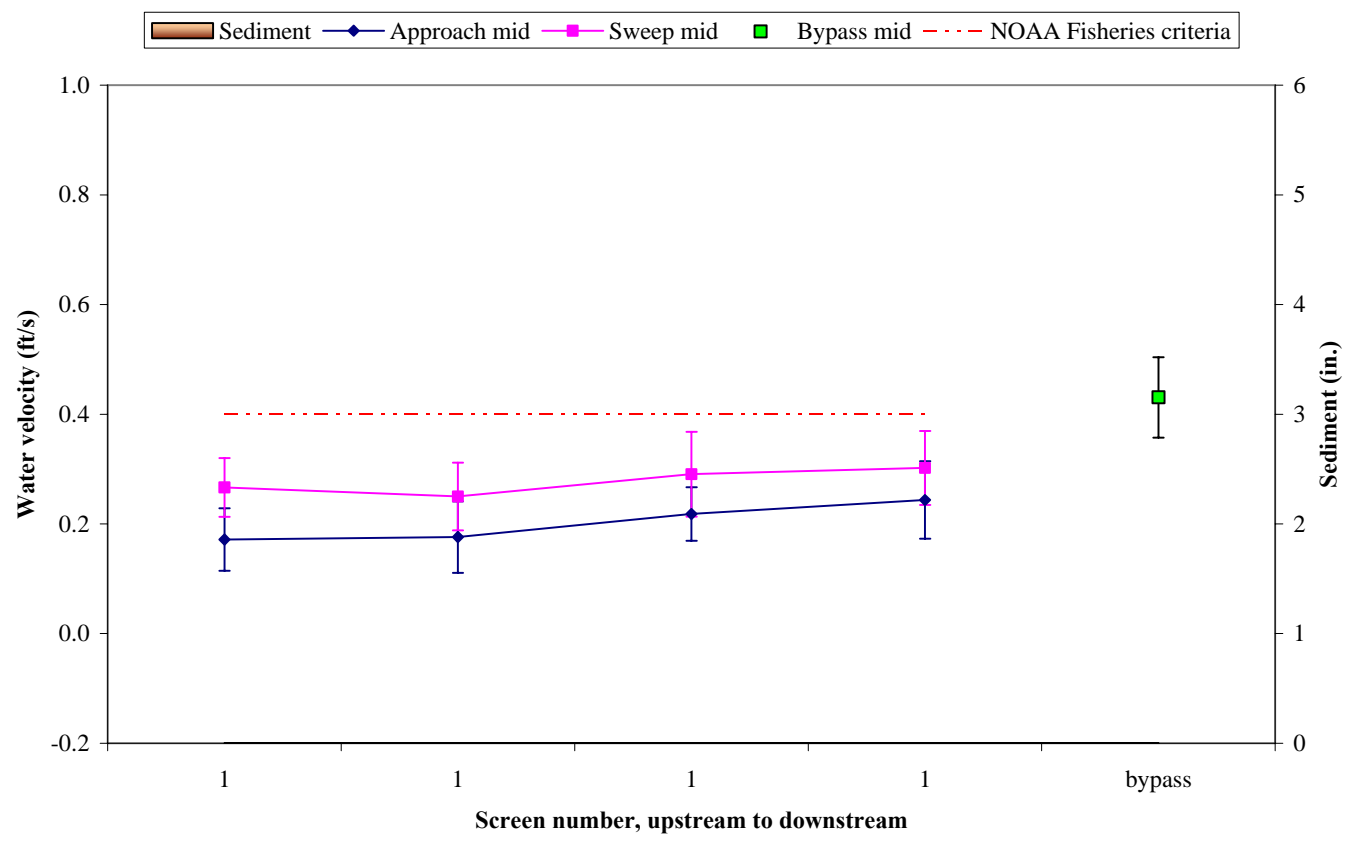

Figure 7. Water velocities and sediment depths at Clark in May 2004. Error bars show turbulence ( \pm the root-mean-squared (RMS)) at each point. 
Clark - July 1, 2004

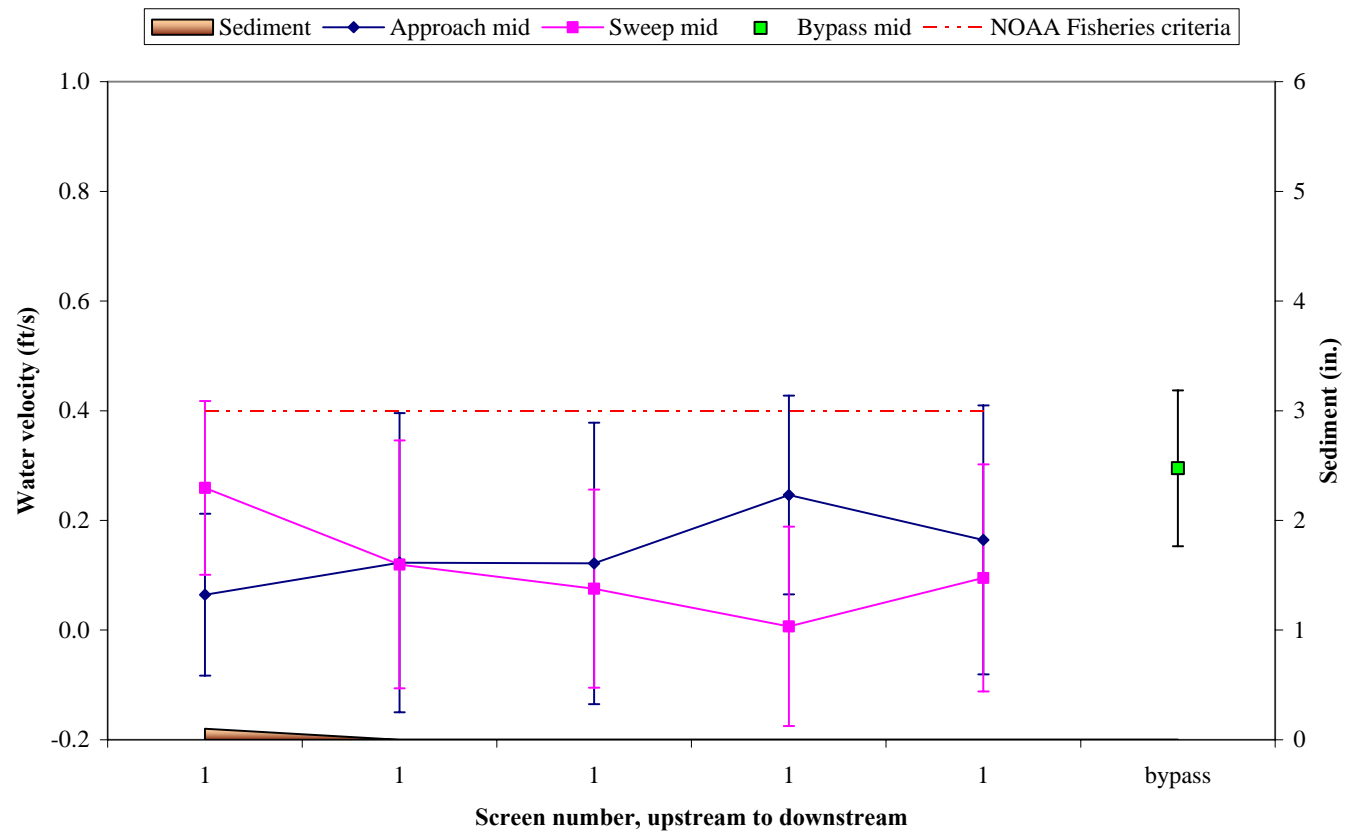

Figure 8. Water velocities and sediment depths at Clark in July 2004. Error bars show turbulence ( \pm the root-mean-squared (RMS)) at each point.

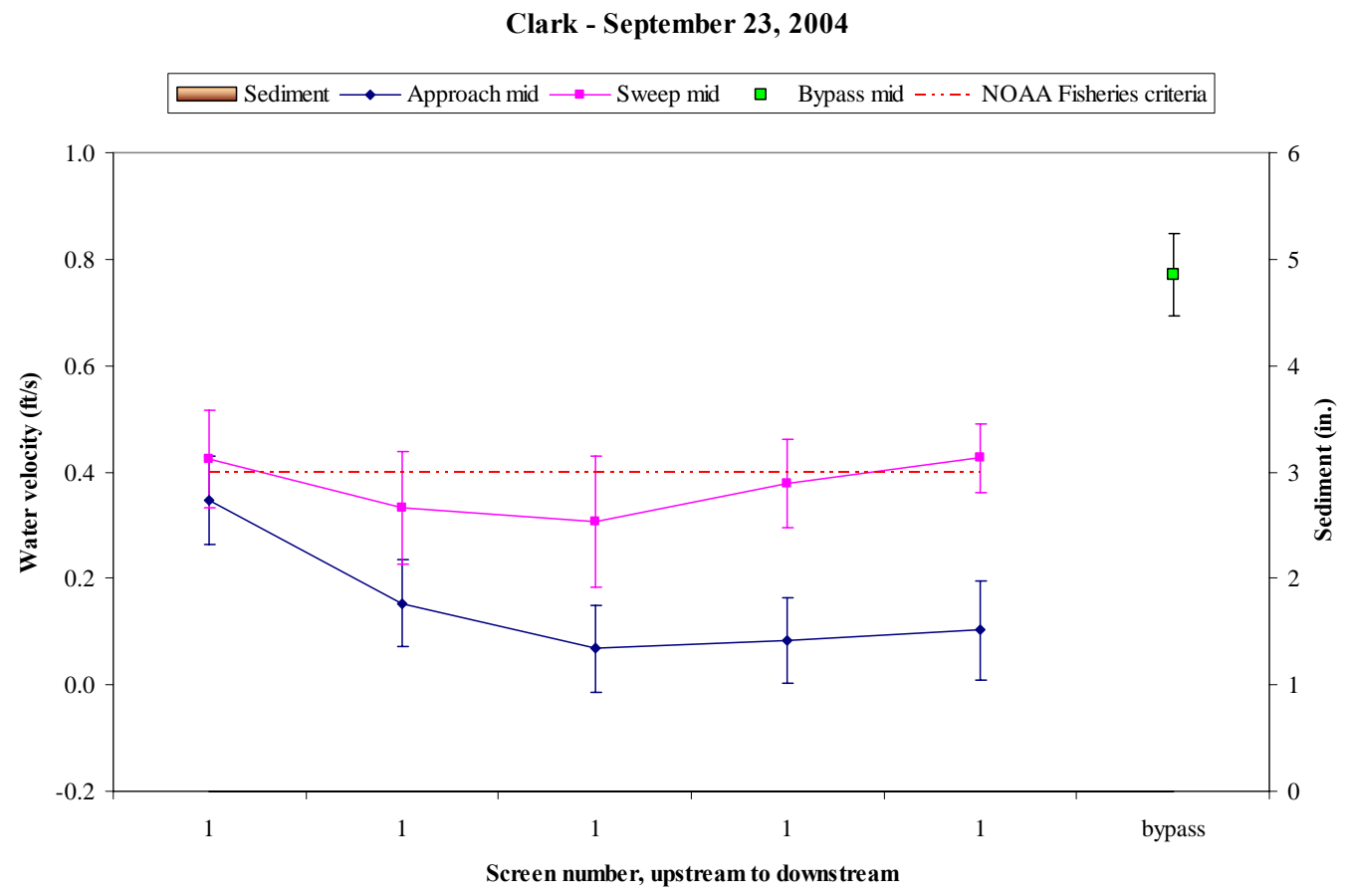

Figure 9. Water velocities and sediment depths at Clark in September 2004. Error bars show turbulence ( \pm the root-mean-squared (RMS)) at each point. 


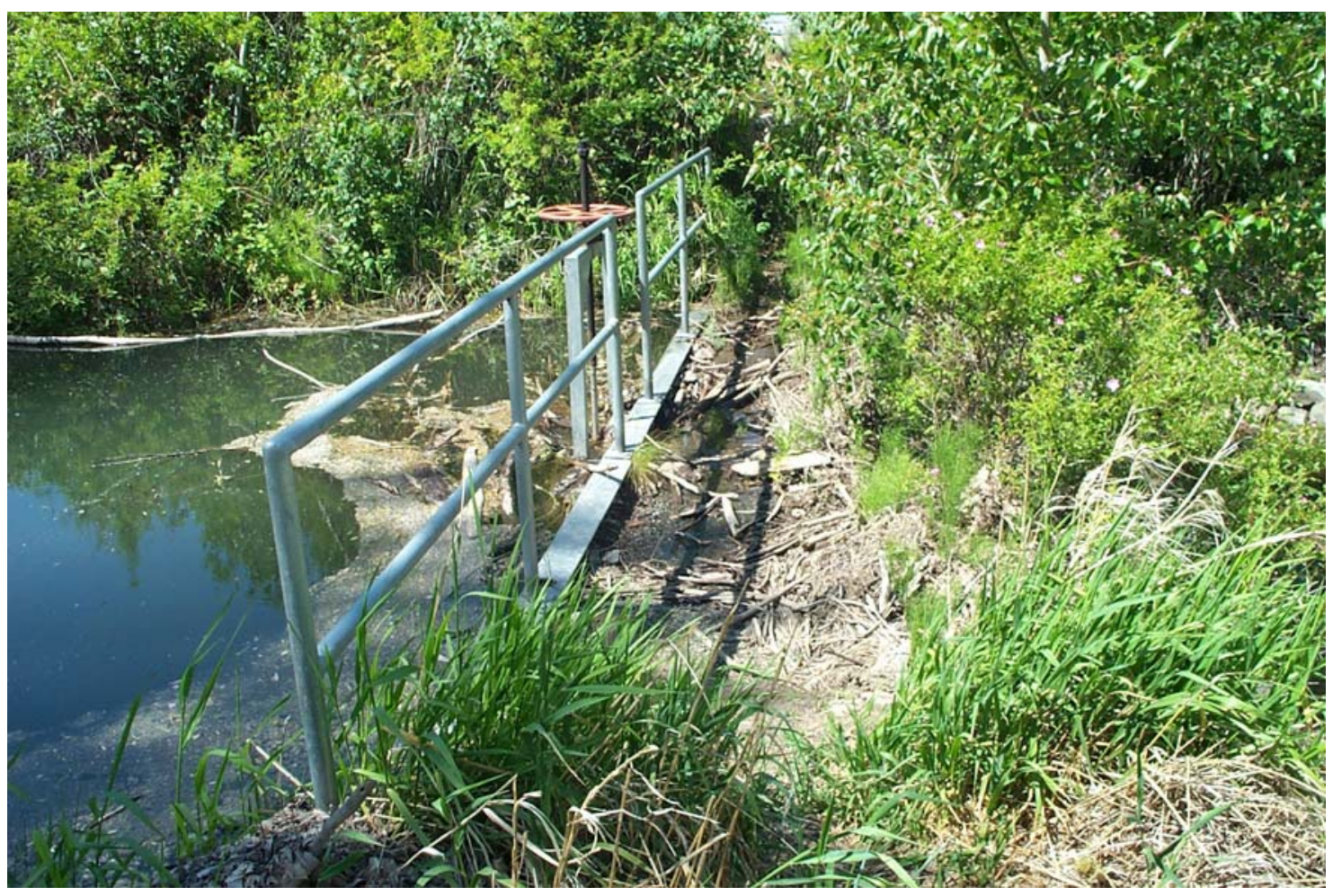

Figure 10. Water beginning to overtop the headgates at Clark in May 2004

\section{Congdon}

The Congdon facility was evaluated on May 21, July 1, and September 23, 2004. In May, June, and September approach velocities met NOAA Fisheries criteria 100, 40, and 93\% of the time, respectively (Figures 11 through 13). Sweep velocities were always higher than approach velocities, although the velocity in the bypass was lower than the average sweep in September. Ray Gilmour was notified on July 1 concerning the high approach velocities, though he said there was nothing to be done because the site was operating within the specifications. On July 21 he pressure-washed the screens, but personnel were unavailable to evaluate whether this improved velocity conditions.

The screen seals were in good condition. There was very little sediment in front of the screens during May and none in July and September. Submergence was very consistent throughout the survey period at 86\% during May, 85\% in June, and 85\% in September. The bypass ramp was partially open in May and July due to debris trapped underneath. This is a condition that should be minimized as it could trap fish behind the ramp with no escape route. The depth of water flowing over the weir and through the outfall met NOAA Fisheries criteria during all surveys, although notes in the logbook state that on July 26 there was no bypass flow and four dead fish were found. Water ran freely through the bypass in May and September, but surged violently at the outfall in July. 


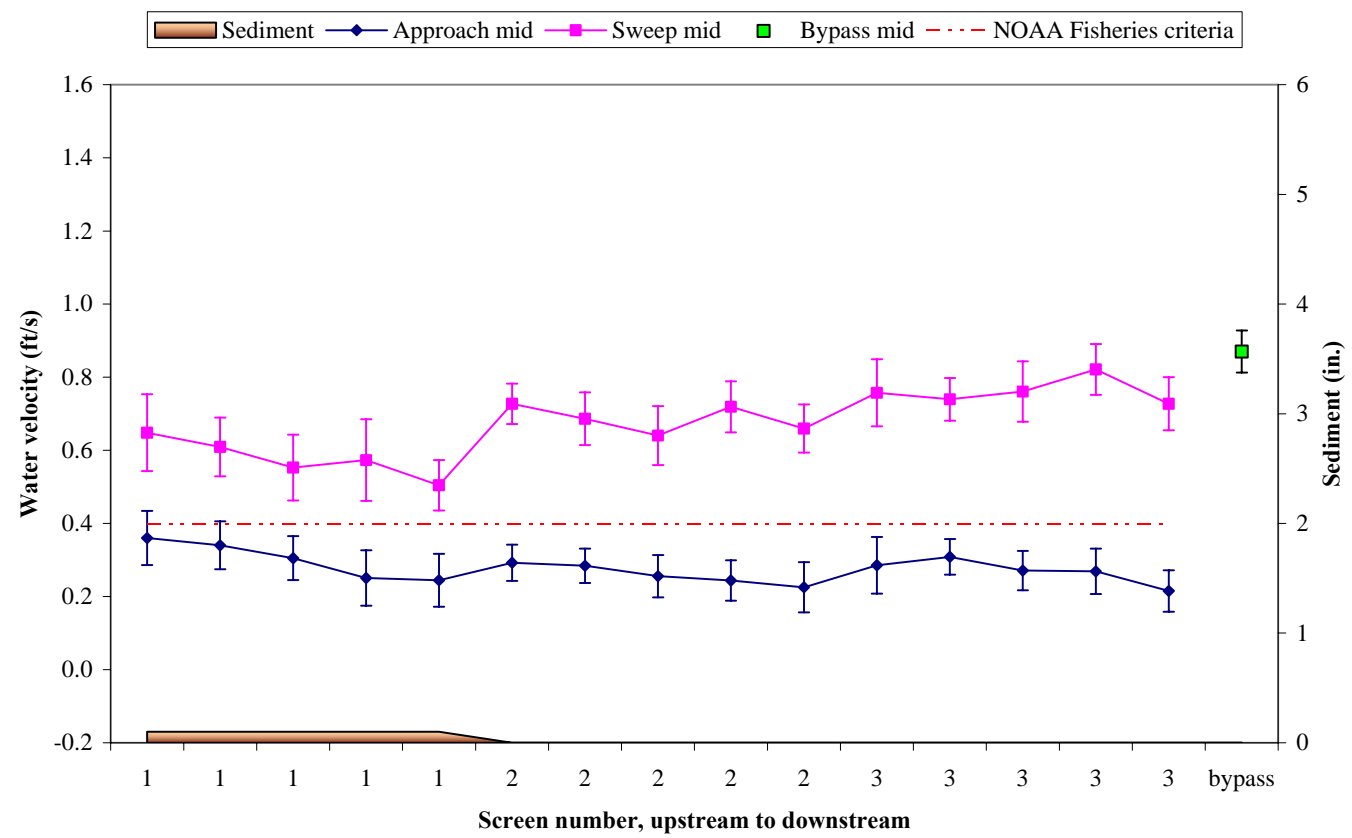

Figure 11. Water velocities and sediment levels at Congdon in May 2004. Error bars show turbulence ( \pm the root-mean-squared (RMS)) at each point.

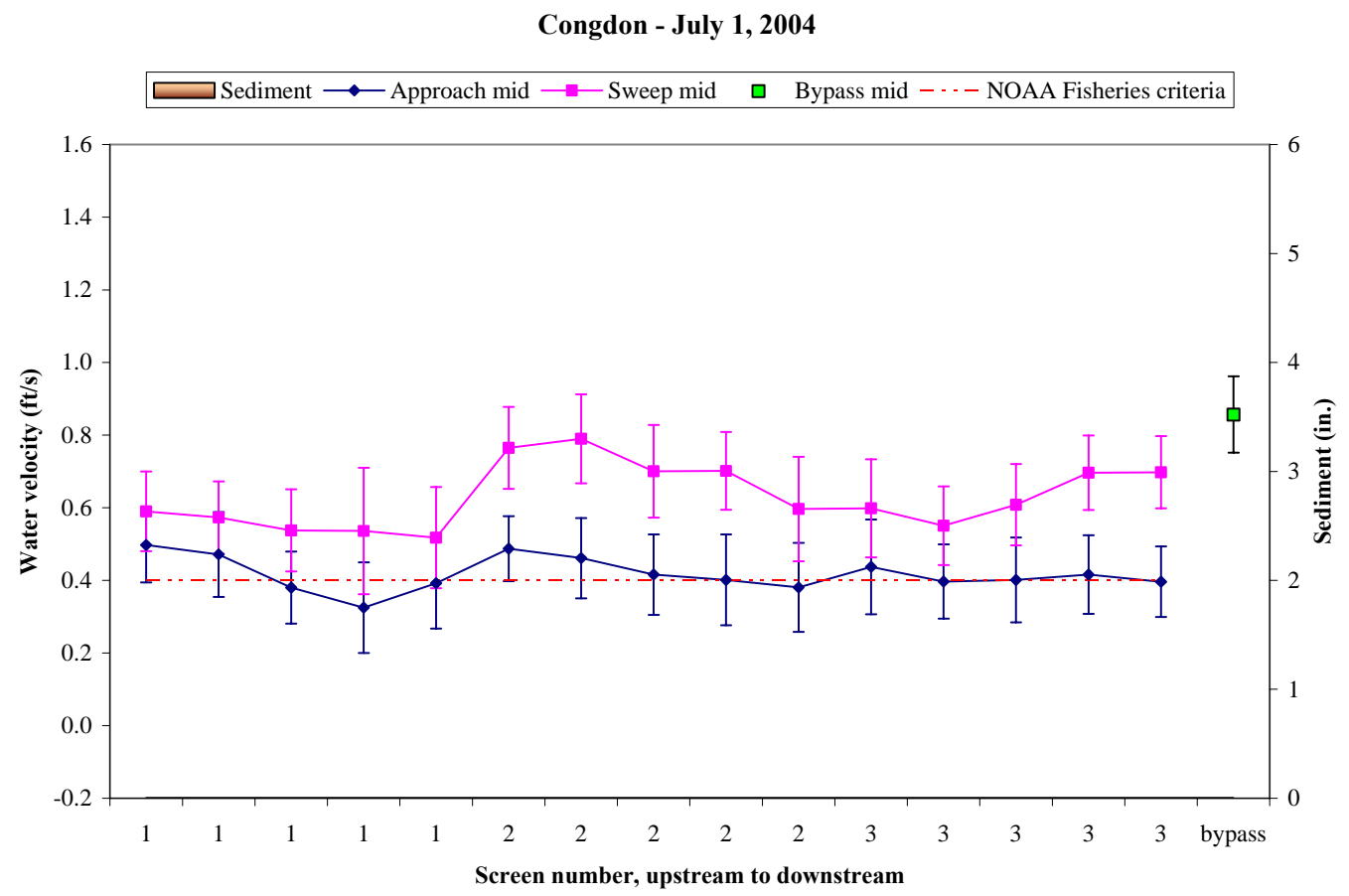

Figure 12. Water velocities and sediment depths at Congdon in July 2004. Error bars show turbulence ( \pm the root-mean-squared (RMS)) at each point. 


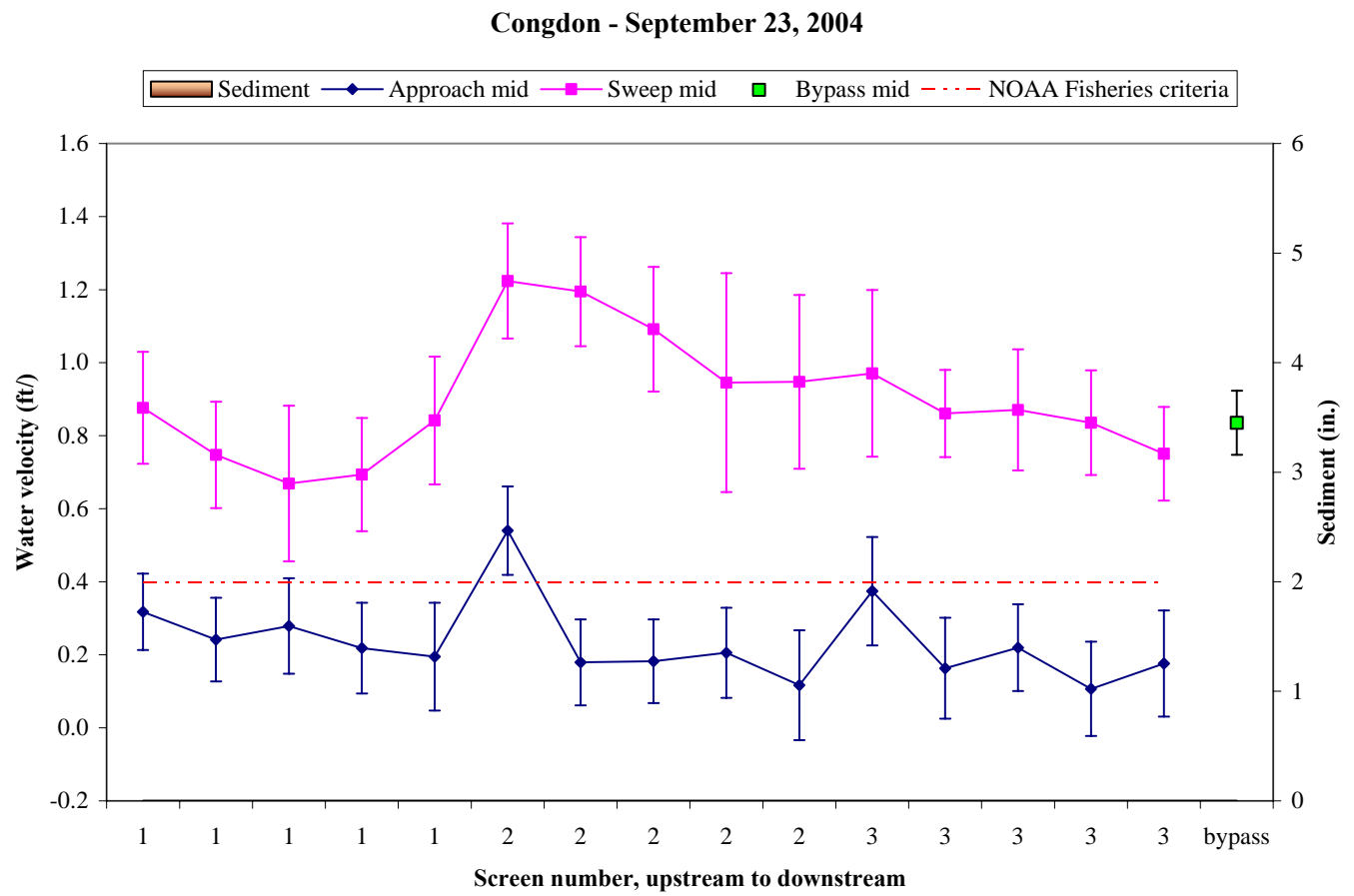

Figure 13. Water velocities and sediment depths at Congdon in September 2004. Error bars show turbulence ( \pm the root-mean-squared (RMS)) at each point.

\section{John Cox}

The John Cox site was evaluated on May 26, June 23, and September 21, 2004, though the site was officially shut down for the season on June 30. In June and September, 100\% of approach velocities met NOAA Fisheries criteria, though in May $70 \%$ of measured approach velocities were greater than $0.4 \mathrm{ft} / \mathrm{s}$ (Figures 14 through 16). Jim Rice was notified concerning the high approach velocities on May 26, though we were not notified of any changes. We followed up during our normally scheduled evaluation in June, and found velocity conditions to be improved. During all surveys the sweep velocity increased towards the downstream end of the site though in June the bypass velocity was less than the average sweep, which was probably due to debris partially blocking the entrance to the outfall pipe.

The screen seals appeared to be in good condition throughout the survey period. Submergence met NOAA Fisheries criteria in May and June, at 82\% and 75\%, respectively, though submergence had dropped to $45 \%$ in September. In June, there was a lot of woody debris in front of the screens, so much so that velocity measurements could not be taken at the downstream end of screen 2 . This debris is not shown in Figure 15 because it covered the entire depth of the water column and was not measured in the typical manner.

In June and September the water depth at the outfall was less than $1 \mathrm{ft}$. It was also noticed in June that the outfall may have been plugged with debris. Jim Rice was notified on June 23 concerning the plug, and he responded on June 25, saying they removed sticks from the outfall. We followed up on June 29 and discovered that flow through the outfall was improved. 


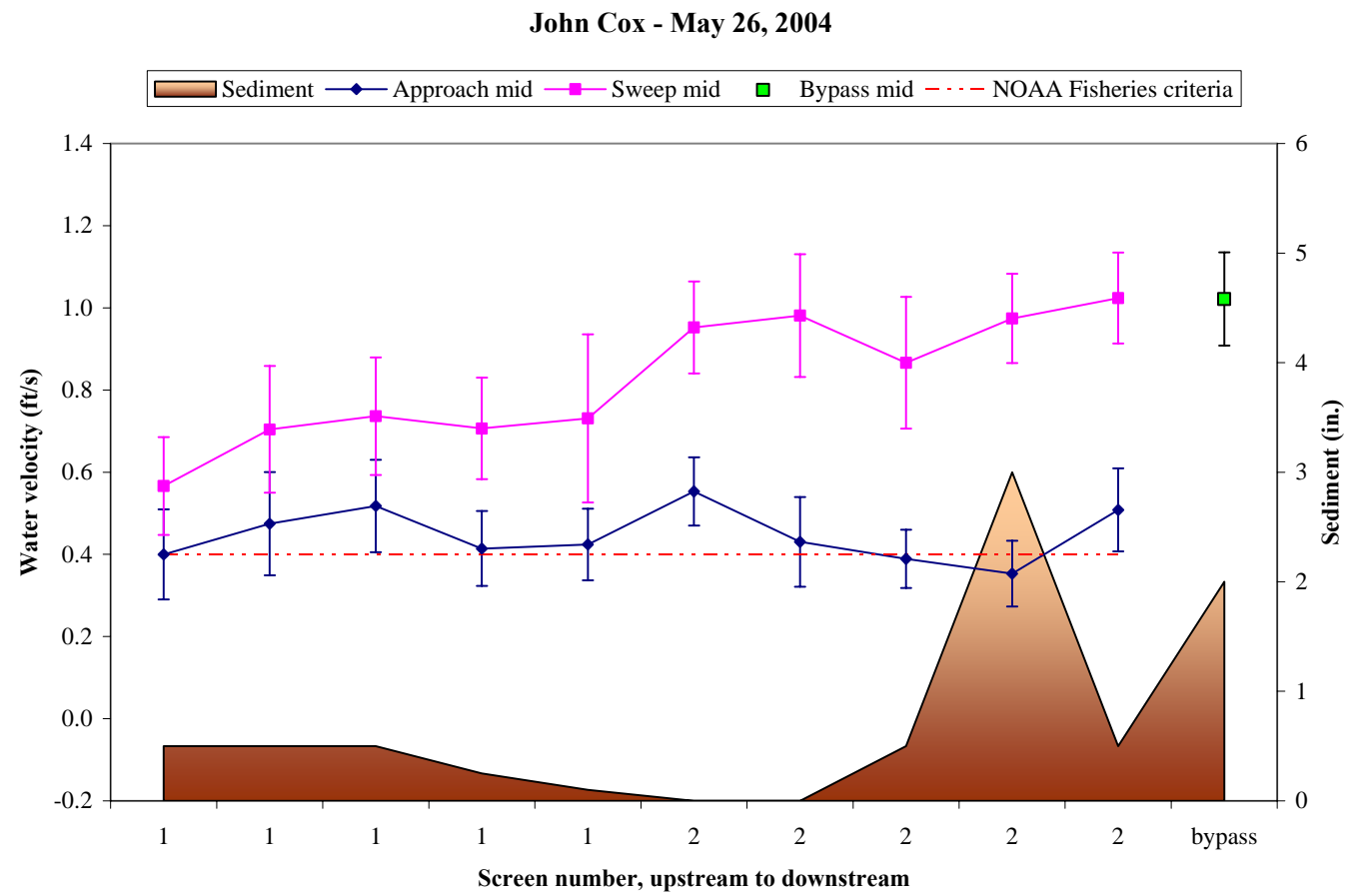

Figure 14. Water velocities and sediment depths at John Cox in May 2004. Error bars show turbulence ( \pm the root-mean-squared (RMS)) at each point.

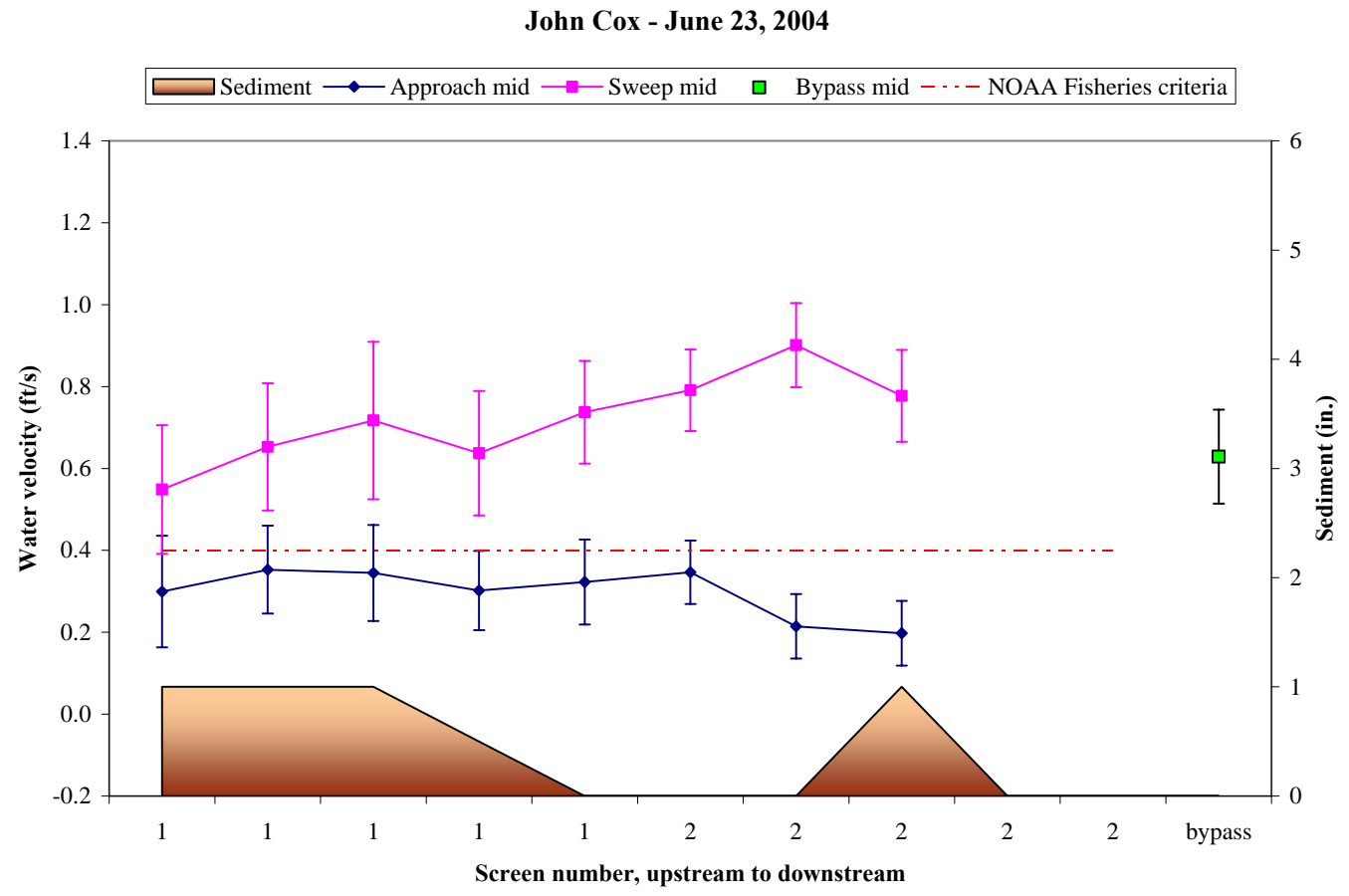

Figure 15. Water velocities and sediment depths at John Cox in June 2004. Error bars show turbulence ( \pm the root-mean-squared (RMS)) at each point. 


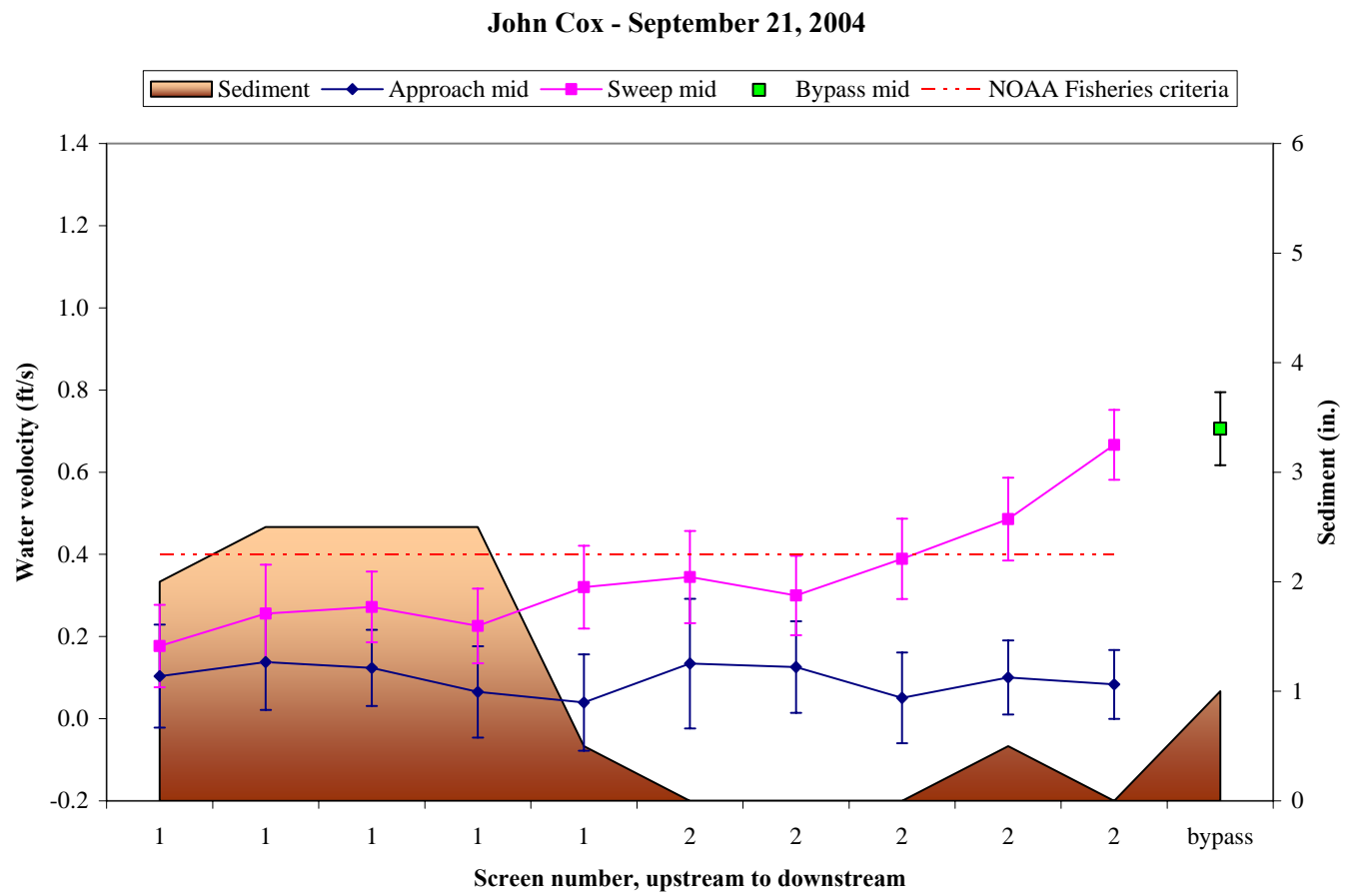

Figure 16. Water velocities and sediment depths at John Cox in September 2004. Error bars show turbulence ( \pm the root-mean-squared (RMS)) at each point.

\section{Kelly-Lowry}

The Kelly-Lowry site was evaluated on May 21, July 1, and September 23, 2004. All approach velocities met NOAA Fisheries criteria in May and July and 80\% met NOAA Fisheries criteria in September (Figures 17 through 19). Sweep velocities were generally higher than approach velocities, though sweep velocities did not increase towards the bypass and the bypass velocity was slower than the average sweep velocity during all surveys.

The screen seals all appeared to be in good condition. A significant amount of debris had built up on the trash rack in September. As in past years, there was a lot of sand in the forebay which gave aquatic plants a place to grow, and by the September survey the forebay was full of plants. Screen submergence was slightly above criteria in May and June, and met criteria in September (86, 87, and 82\%, respectively).

Bypass conditions were conducive to safe fish passage in May and appeared to be passable in July and September, though the path to the outfall was too overgrown in June and September to measure it. Water ran freely over the weir, and the PNNL staff did not observe any accumulation of debris at the outfall pipe. The depth of water at the outfall was greater than $1 \mathrm{ft}$ in May, and appeared to be greater than $1 \mathrm{ft}$ in July and September. Water discharge at the outfall surged slightly in May, and was smooth in July and September.

Operator control aids were present, though the submergence marks on the drum screen frame were beginning to fade by the September survey. 


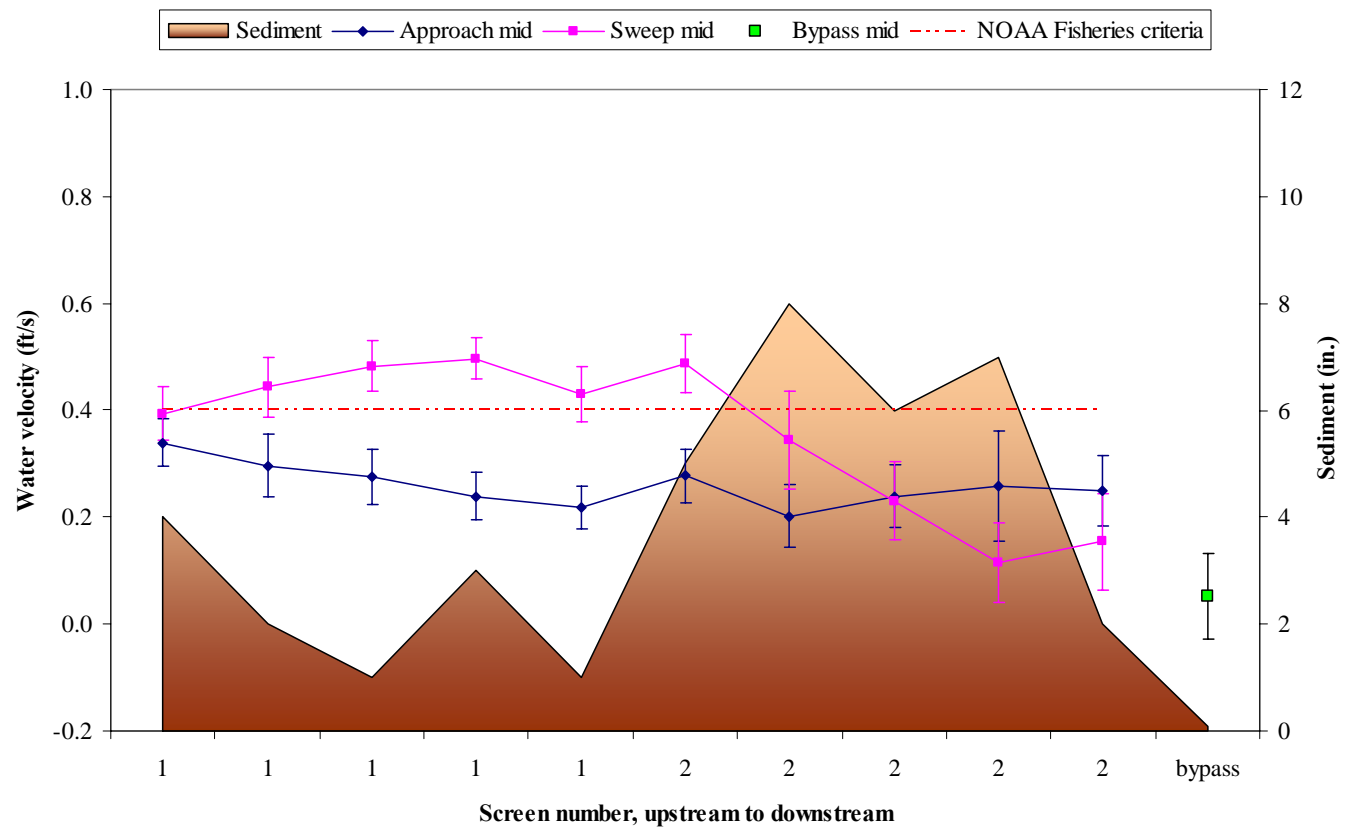

Figure 17. Water velocities and sediment depths at Kelly-Lowry in May 2004. Error bars show turbulence ( \pm the root-mean-squared (RMS)) at each point.

\section{Kelly-Lowry - July 1, 2004}

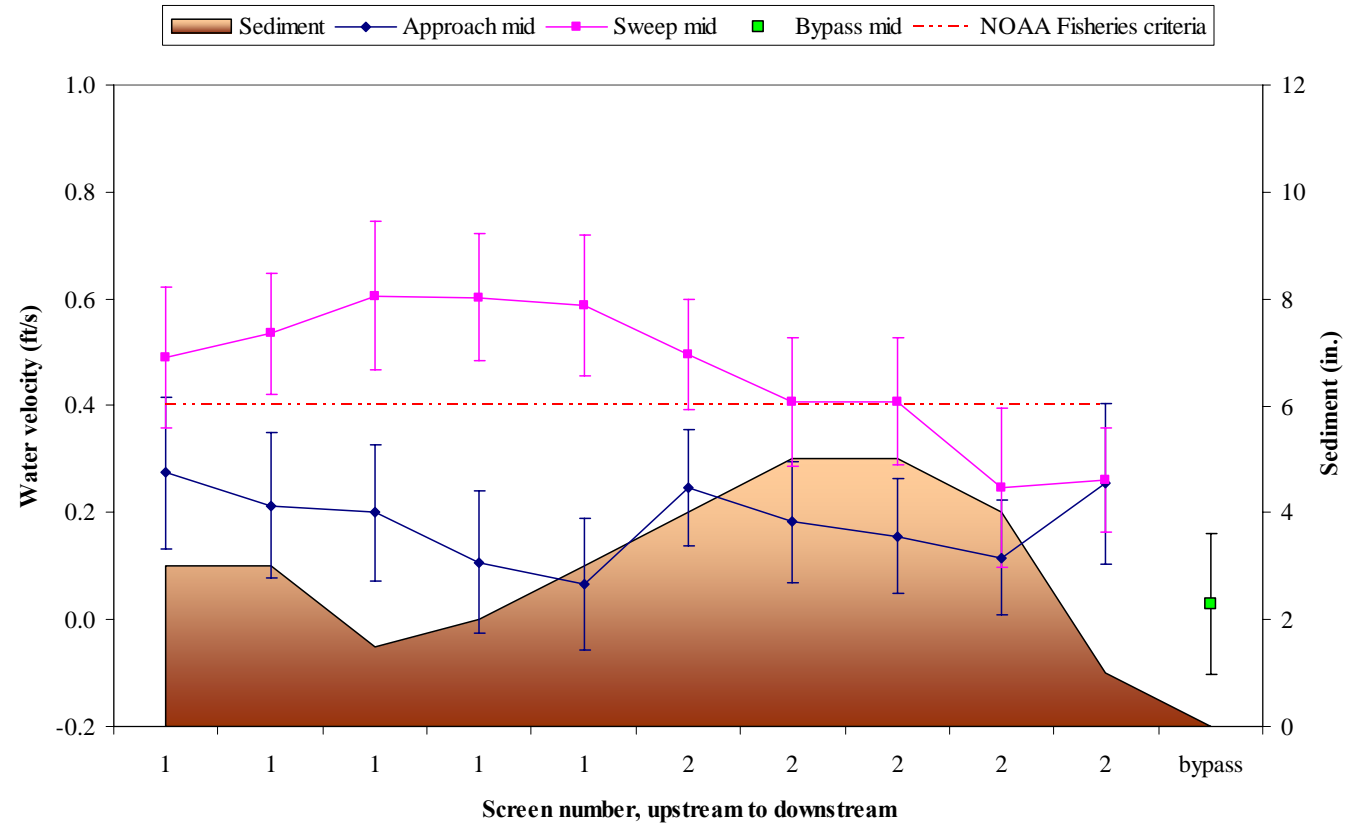

Figure 18. Water velocities and sediment depths at Kelly-Lowry in July 2004. Error bars show turbulence ( \pm the root-mean-squared (RMS)) at each point. 


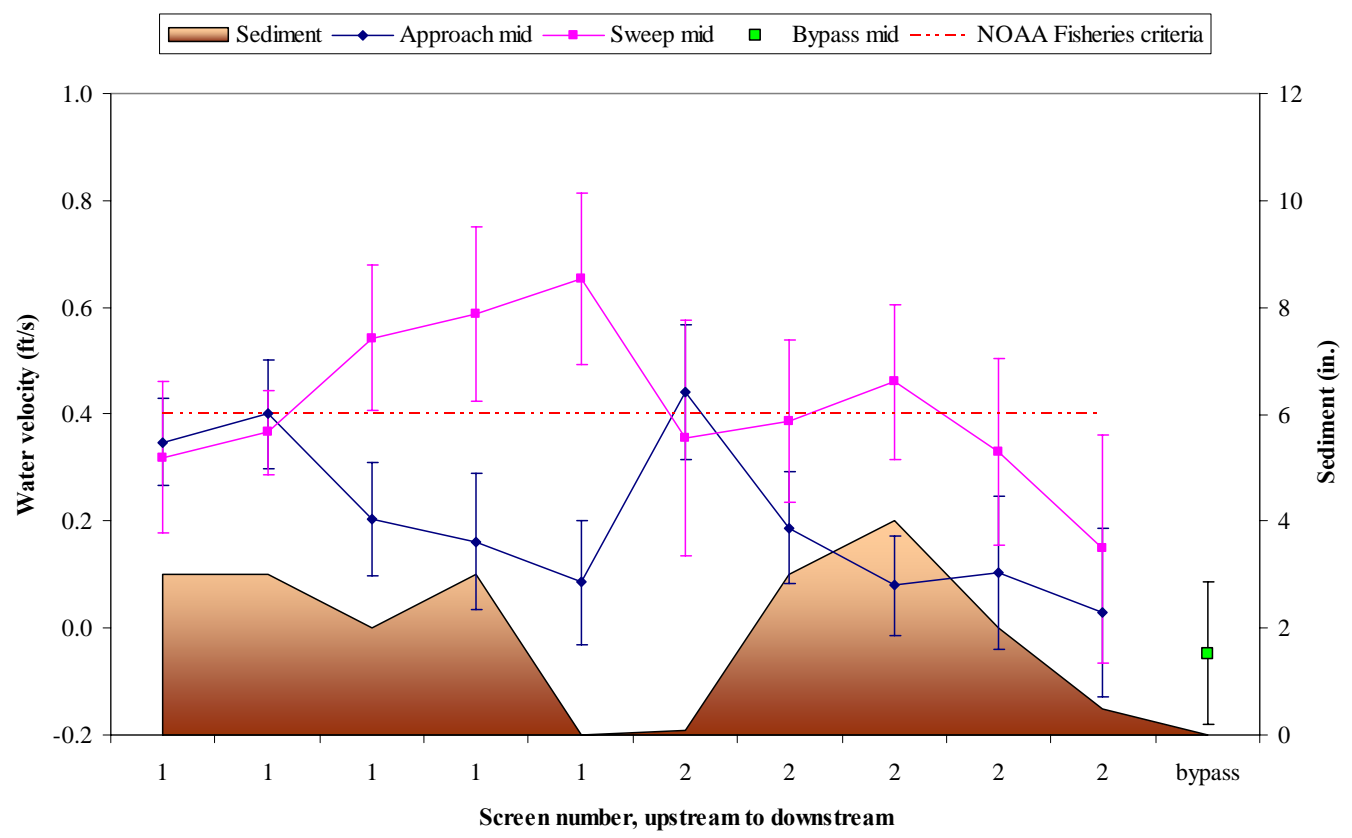

Figure 19. Water velocities and sediment depths at Kelly-Lowry in September 2004. Error bars show turbulence ( \pm the root-mean-squared (RMS)) at each point.

\section{Lindsey}

The Lindsey site was evaluated on May 20, June 24, and September 24, 2004. During all surveys, $100 \%$ of approach velocity values met NOAA Fisheries criteria (Figures 20 through 22). Sweep velocities were greater than approach velocities and the bypass velocity was greater than the average sweep velocity during all surveys. In June, sweep increased from the upstream end of the site towards the bypass.

The screen seals were in good condition, and the drum moved leaf matter and other floating debris into the canal effectively. Submergence was at the low end of the criteria range at $65 \%$ in May, above the criteria in June at 89\%, and met criteria in September at 70\%. Only 1 in. of water flowed over the bypass in May, though Ray Gilmour was there putting check boards behind the screens to create more submergence and bypass flow. The gaps between the metal frame of the screen and the cement wall were filled with expanding foam insulation that will prevent entrainment of small fish in these gaps.

Bypass conditions were conducive to safe fish passage. Water flowed freely over the weir and through the outfall, where the depth was always greater than $1 \mathrm{ft}$. 


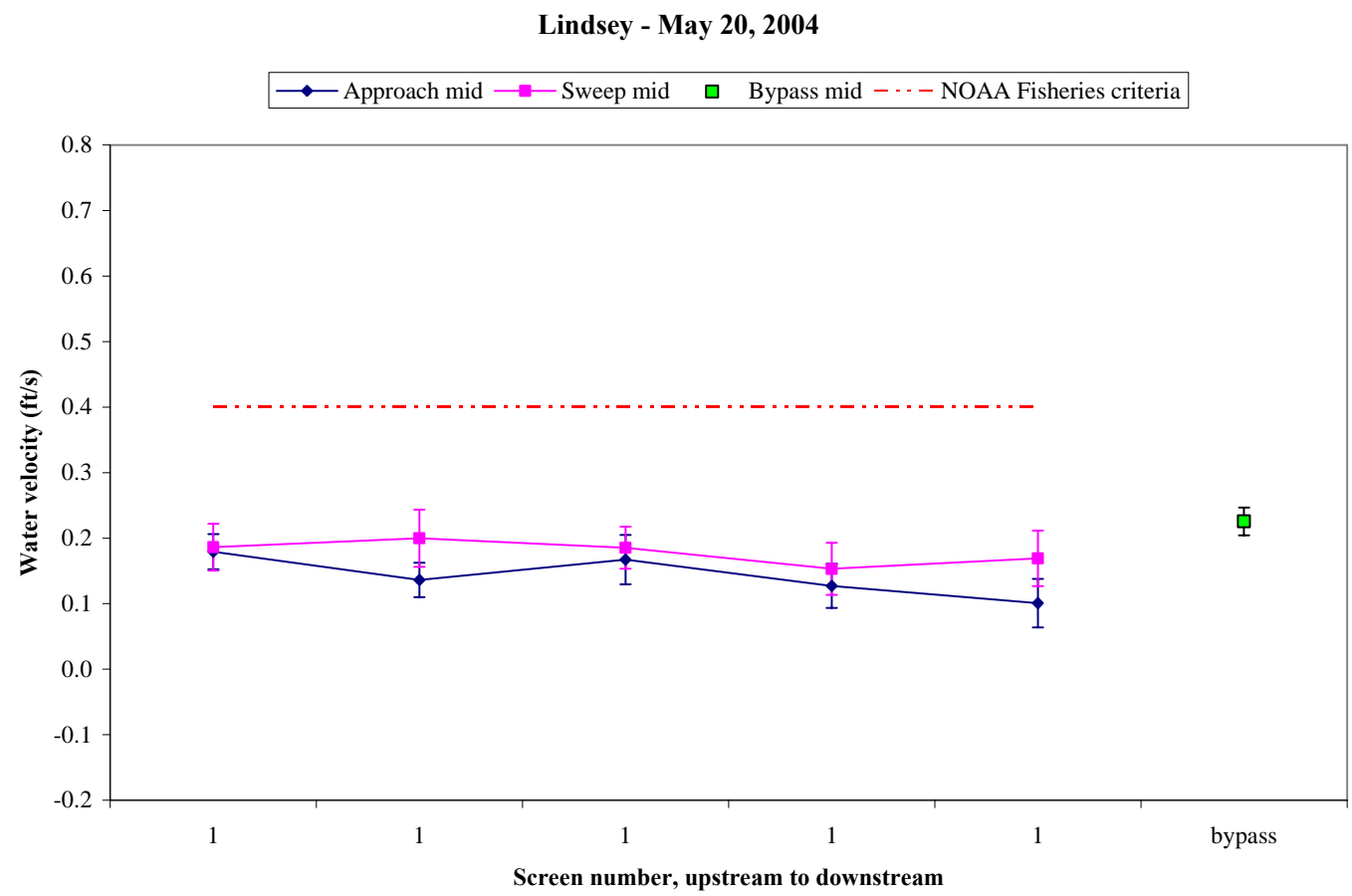

Figure 20. Water velocities and sediment depths at Lindsey in May 2004. Error bars show turbulence ( \pm the root-mean-squared (RMS)) at each point.

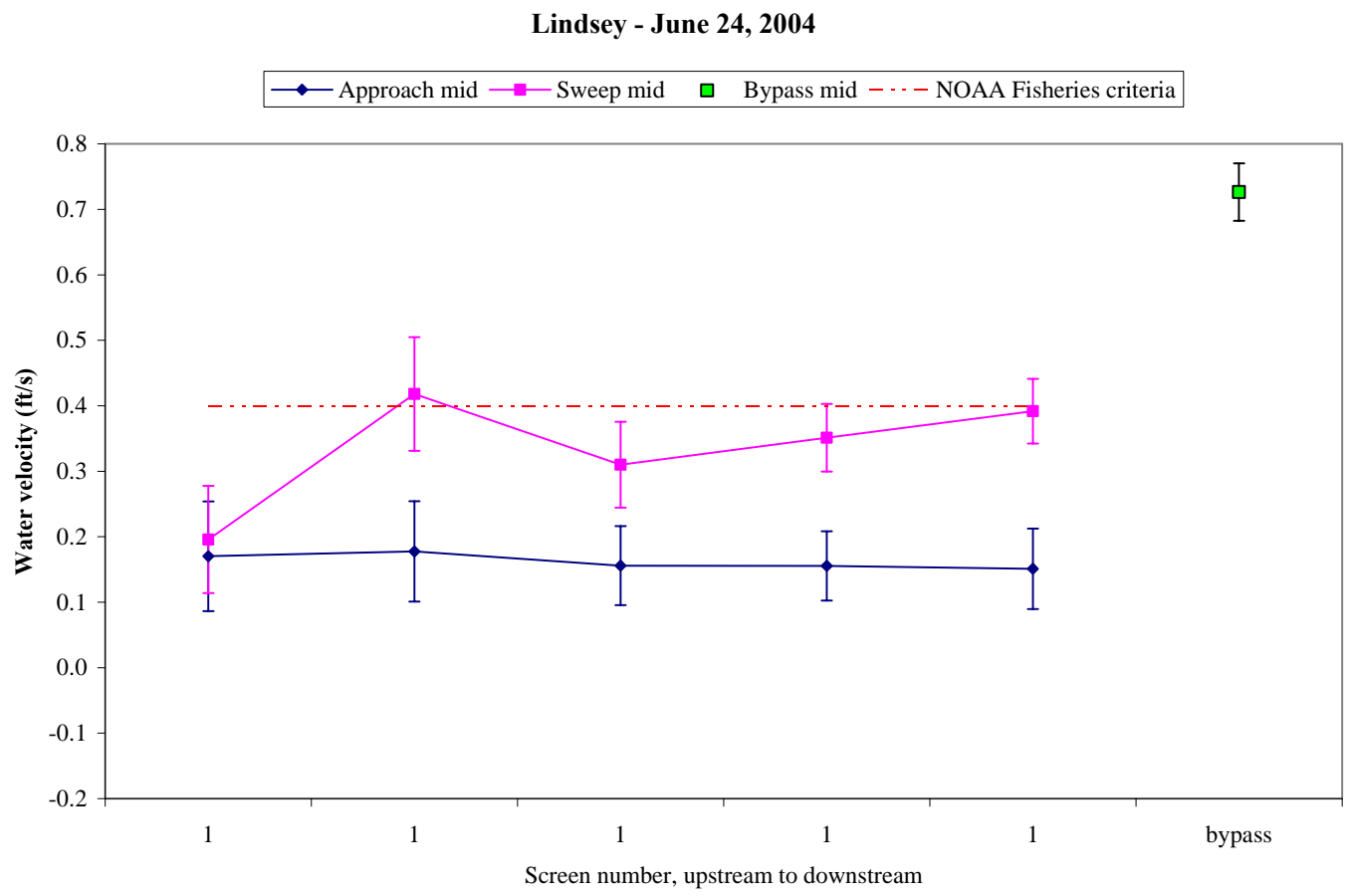

Figure 21. Water velocities and sediment depths at Lindsey in June 2004. Error bars show turbulence ( \pm the root-mean-squared (RMS)) at each point. 


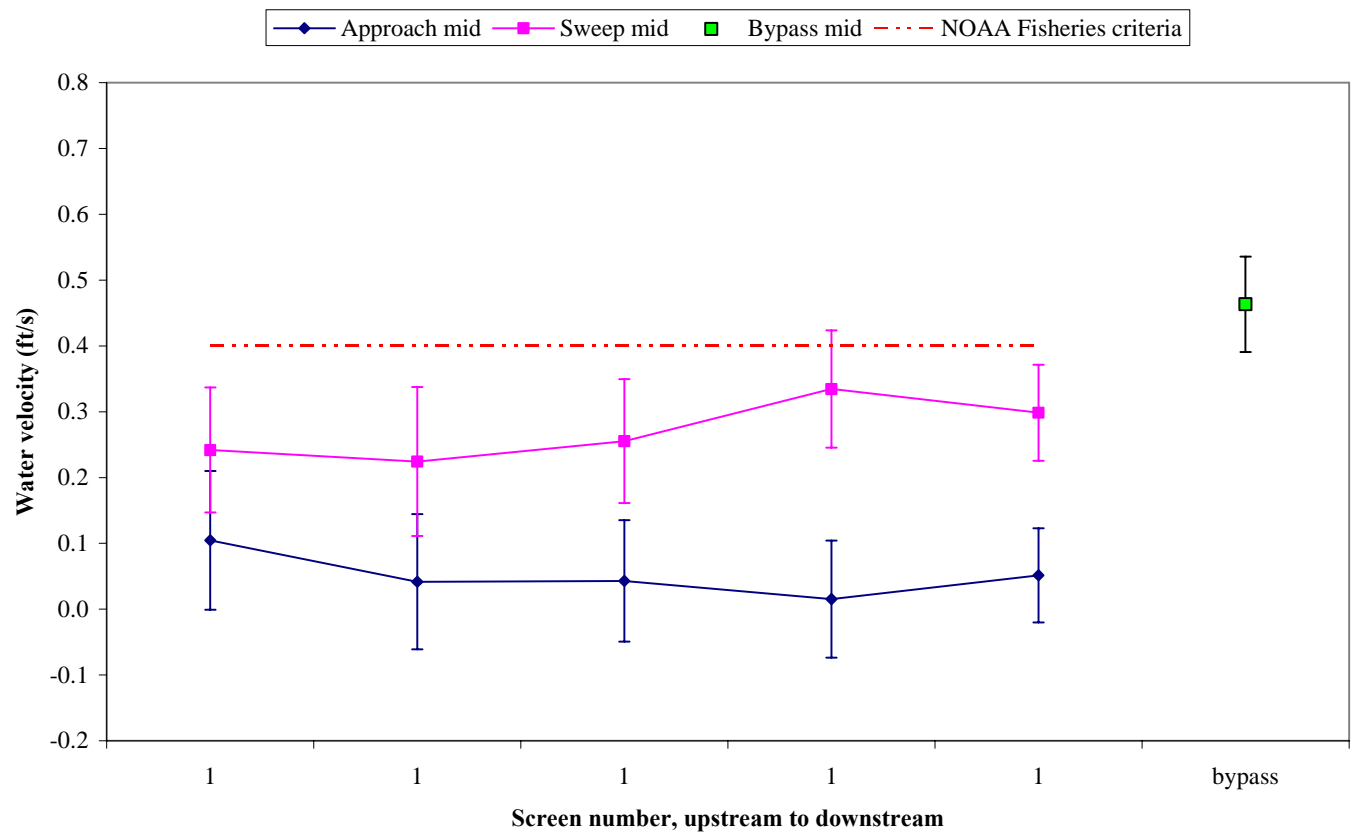

Figure 22. Water velocities and sediment depths at Lindsey in September 2004. Error bars show turbulence ( \pm the root-mean-squared (RMS)) at each point.

\section{Lower Wapato Irrigation Project (WIP)}

The Lower WIP site was visited on May 26, June 23, and September 21, 2004, though the site stopped receiving water on June 24 and was officially shut down for the season on September 16 . All approach velocities met NOAA Fisheries criteria during all surveys. Sweep velocities were less than approach velocities in May and June, and the bypass velocity was less than the average sweep velocity in May (Figures 23 and 24). Sweep velocities did not increase towards the downstream end of the site. In May and June, water flowed backwards from the downwell into the bypass, and notes in the logbook indicated that this condition persisted for the majority of the irrigation season. This has happened in the past, but has occurred more frequently in the past 2 years. These conditions could lead to delay for migrating fish.

In June an excessive amount of sand was present in the forebay, in front of the screens, and in the bypass. Submergence barely met criteria in May at $65 \%$ and fell to $46 \%$ in June. The combination of low submergence and excessive sediment precluded velocity measurements at screen one in June. Jim Rice was notified about the excessive sediment and reverse bypass velocities on June 23. We did not receive a response; however, sediment deposits at the site were removed in September. Bypass outfall conditions met NOAA Fisheries criteria during all surveys. The screens and seals that were visible (i.e., not obstructed by sediment or debris) appeared to be in good condition. 


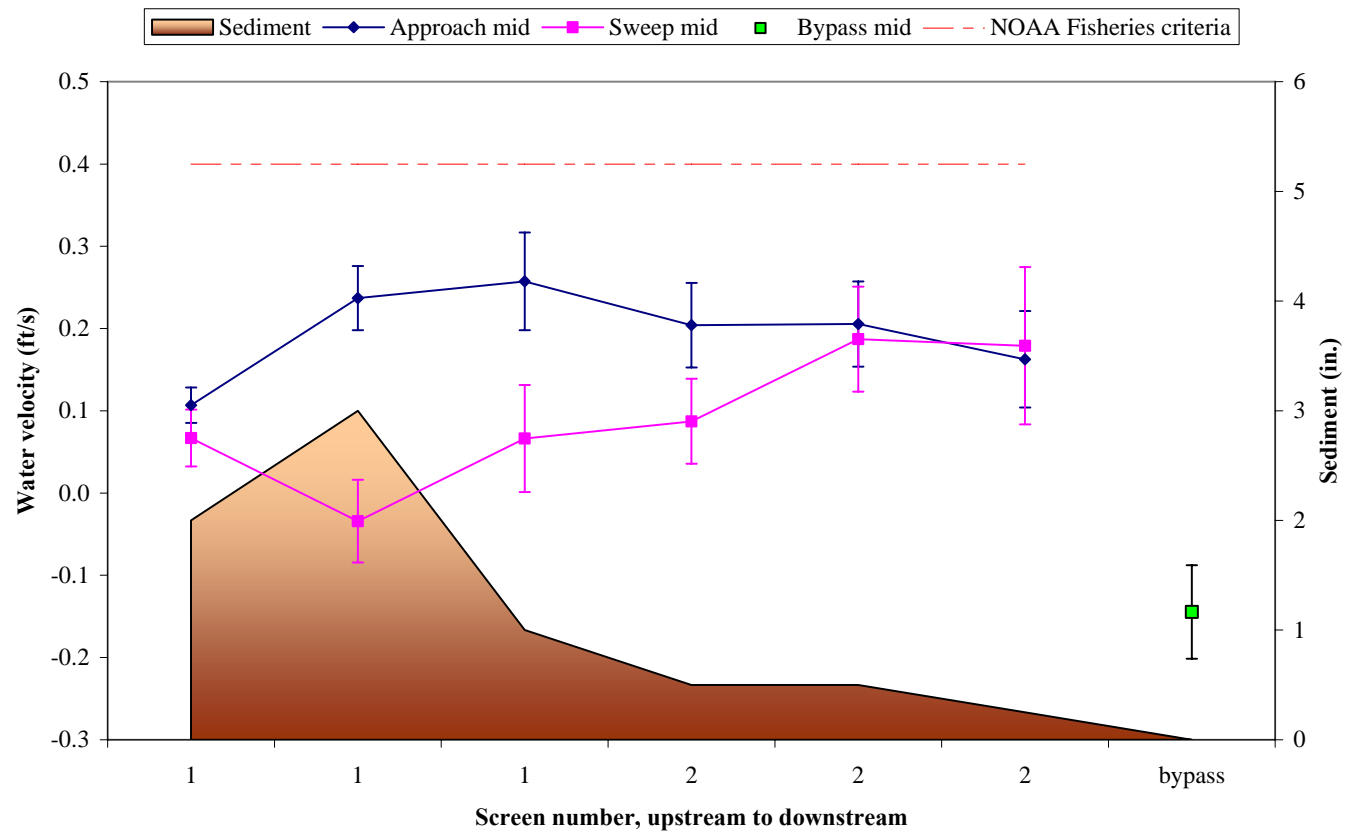

Figure 23. Water velocities and sediment depths at Lower Wapato Irrigation Project (WIP) in May 2004. Error bars show turbulence ( \pm the root-mean-squared (RMS)) at each point.

Lower WIP - June 23, 2004

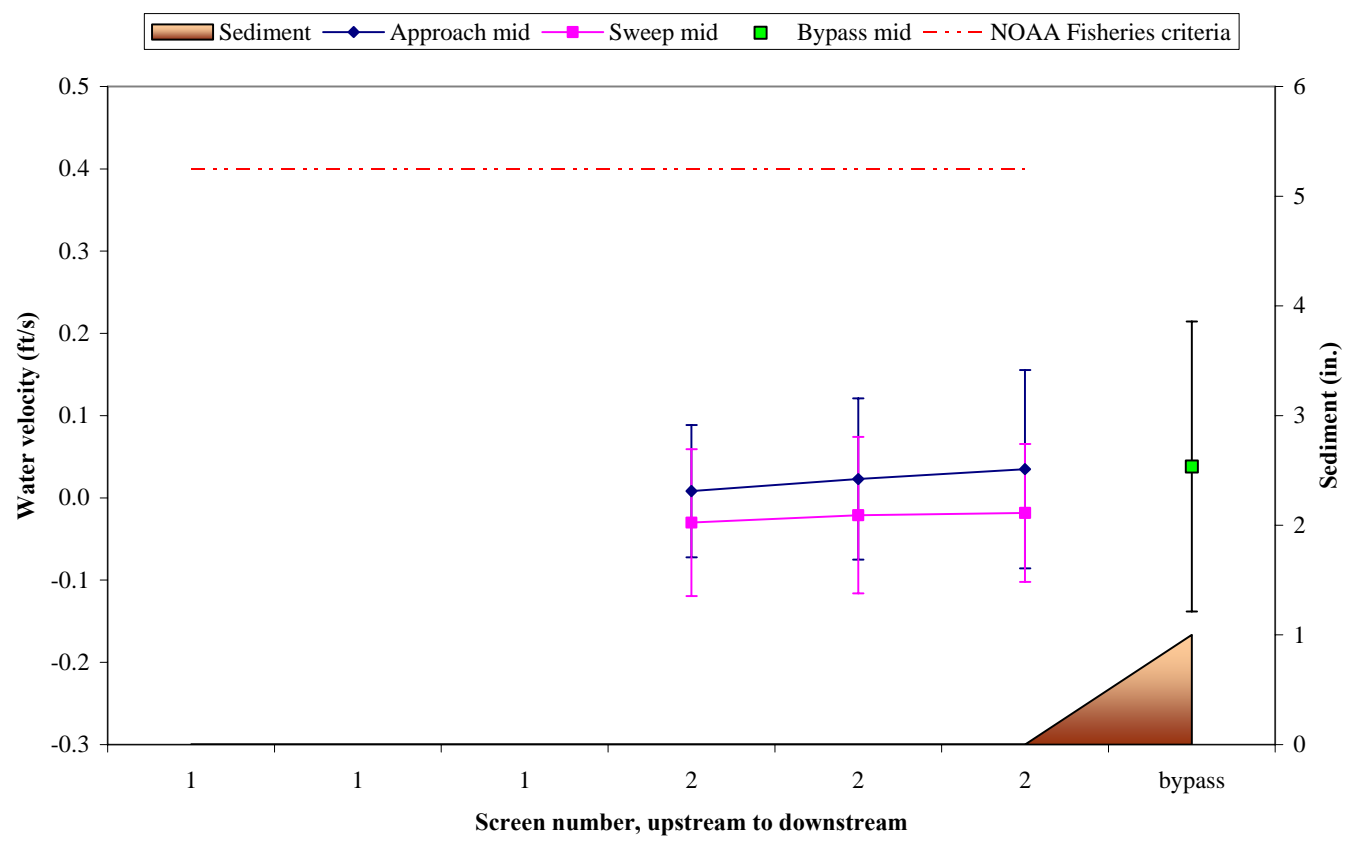

Figure 24. Water velocities and sediment depths at Lower Wapato Irrigation Project (WIP) in June 2004. Error bars show turbulence ( \pm the root-mean-squared (RMS)) at each point. 


\section{Naches-Cowiche}

The Naches-Cowiche site was evaluated on May 21, June 22, and September 23, 2004. During May and September, 100\% of approach values met NOAA Fisheries criteria, though only $85 \%$ of approach velocities met NOAA Fisheries criteria in June (Figures 25 through 27). Ray Gilmour was notified on June 23 concerning the high approach velocities. He responded the next day by adding a checkboard in the aftbay to raise the submergence. We followed up on June 24 and found that the change had improved the velocity conditions. Sweep velocities were generally higher than approach velocities but did not increase towards the bypass. The average bypass velocity was faster than the average sweep velocity during May and September, but not in June.

The stoplogs in front of screen 2 had been removed, but the stoplog in front of screen 1 still prevented an evaluation of the bottom seal there with the video camera. All other visible seals were in good condition. Submergence was within criteria during all visits and bypass conditions were generally good for safe fish passage. Ecology blocks were placed around the outfall in the summer of 2003 to prevent it from becoming blocked by rocks shifting in the river, and this appeared to be working in June when we were able to access the outfall to look at it. In June, two large trout were observed in the canal behind the screens.

\section{Naches-Cowiche - May 21, 2004}

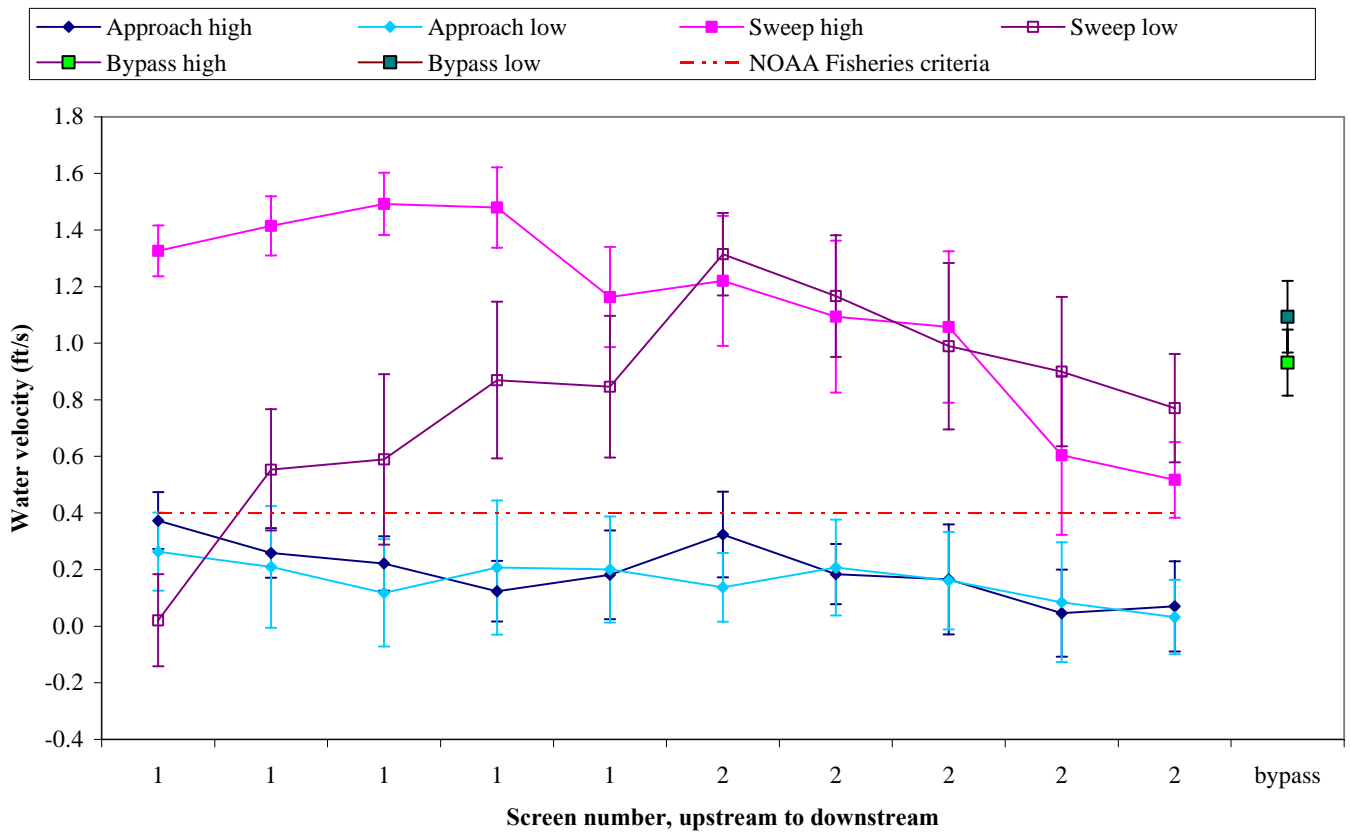

Figure 25. Water velocities and sediment depths at Naches-Cowiche in May 2004. Error bars show turbulence ( \pm the root-mean-squared (RMS)) at each point. 


\section{Naches-Cowiche - June 22, 2004}

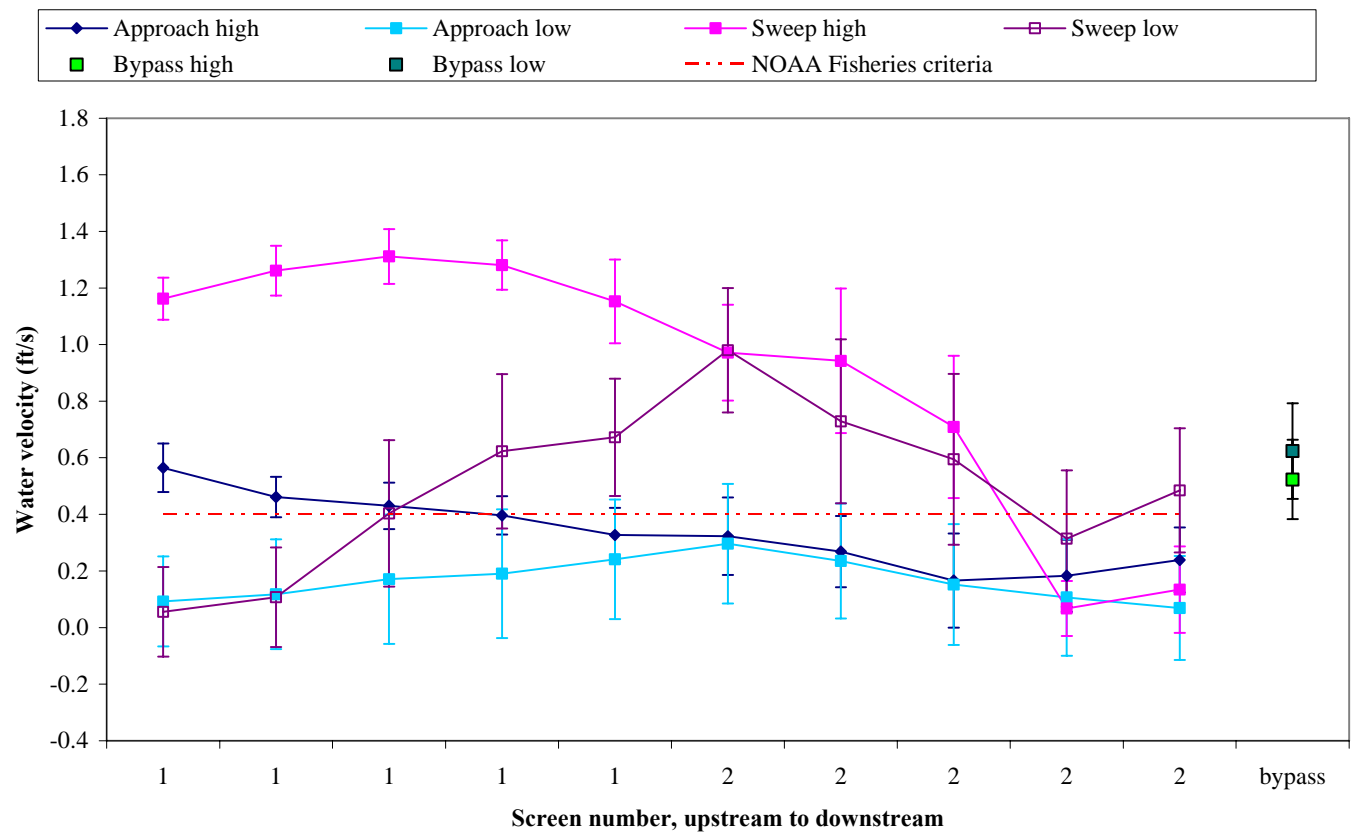

Figure 26. Water velocities and sediment depths at Naches-Cowiche in June 2004. Error bars show turbulence ( \pm the root-mean-squared (RMS)) at each point.

Naches-Cowiche - September 23, 2004

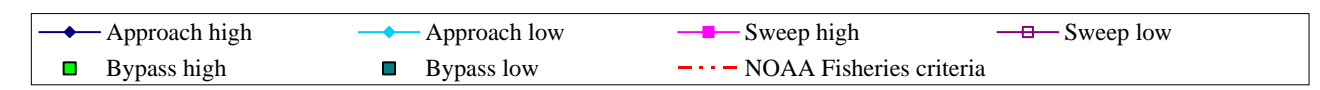

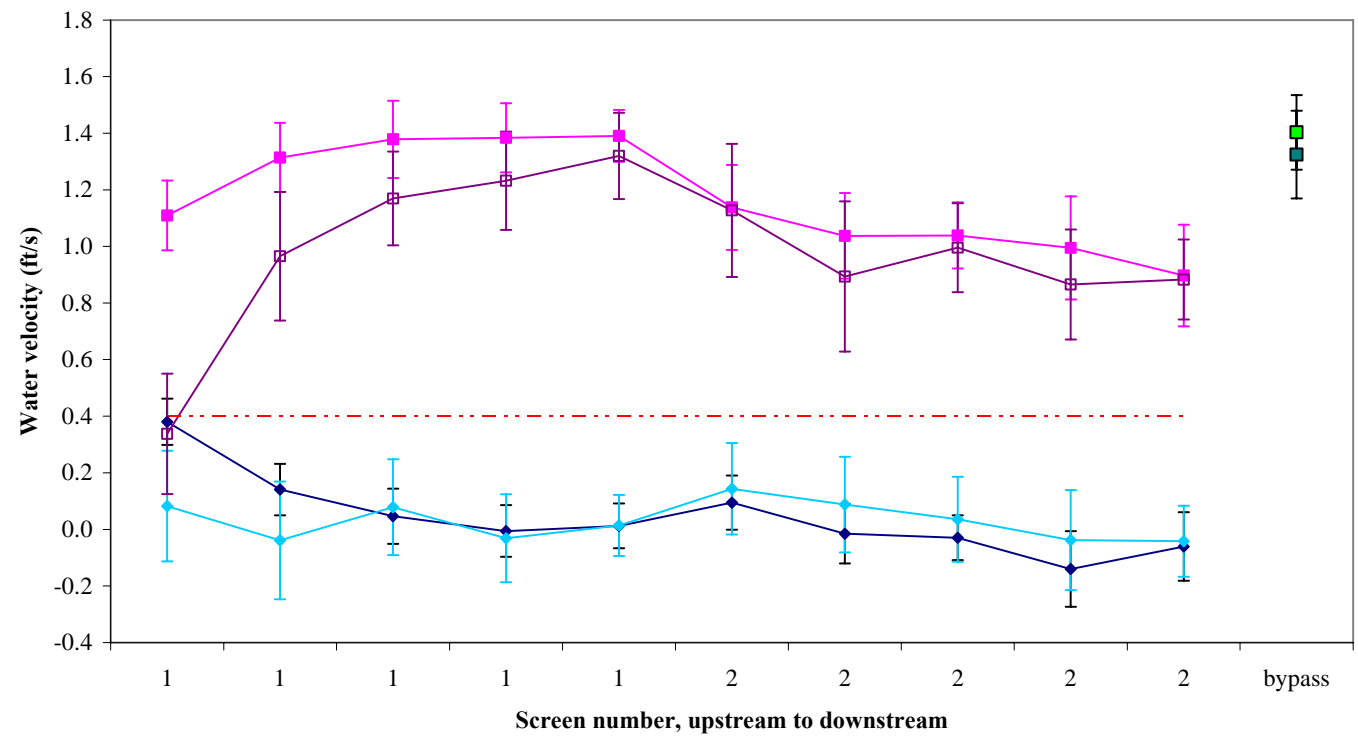

Figure 27. Water velocities and sediment depths at Naches-Cowiche in September 2004. Error bars show turbulence ( \pm the root-mean-squared (RMS)) at each point. 


\section{New Cascade}

The New Cascade site was evaluated on May 27, June 28, and September 27, 2004. In May and June, $100 \%$ of approach velocities met NOAA Fisheries criteria, and in September that figure dropped slightly to 95\% (Figures 28 through 30). Sweep velocities were generally greater than approach velocities, and sweep velocities increased slightly towards the bypass in June. Bypass velocities were greater than the average sweep velocity during September.

Submergence slightly exceeded criteria in May, June and September, at 88, 87, and 89\%, respectively. In the past this site has had problems with sediment buildup, especially in the downstream corners of the screen bays. There was some evidence of this problem in May, but conditions in June and September were generally very good. All screens and seals appeared to be in good condition, and all cheeks were sealed with expanding foam insulation.

Bypass conditions were conducive to safe fish passage during all surveys. Water flowed freely over the weir and through the outfall, though the depth at the outfall was less than $1 \mathrm{ft}$ in May and September. However, the depth in the stream just beyond the outfall apron was greater than 12 in.

New Cascade - May 27, 2004

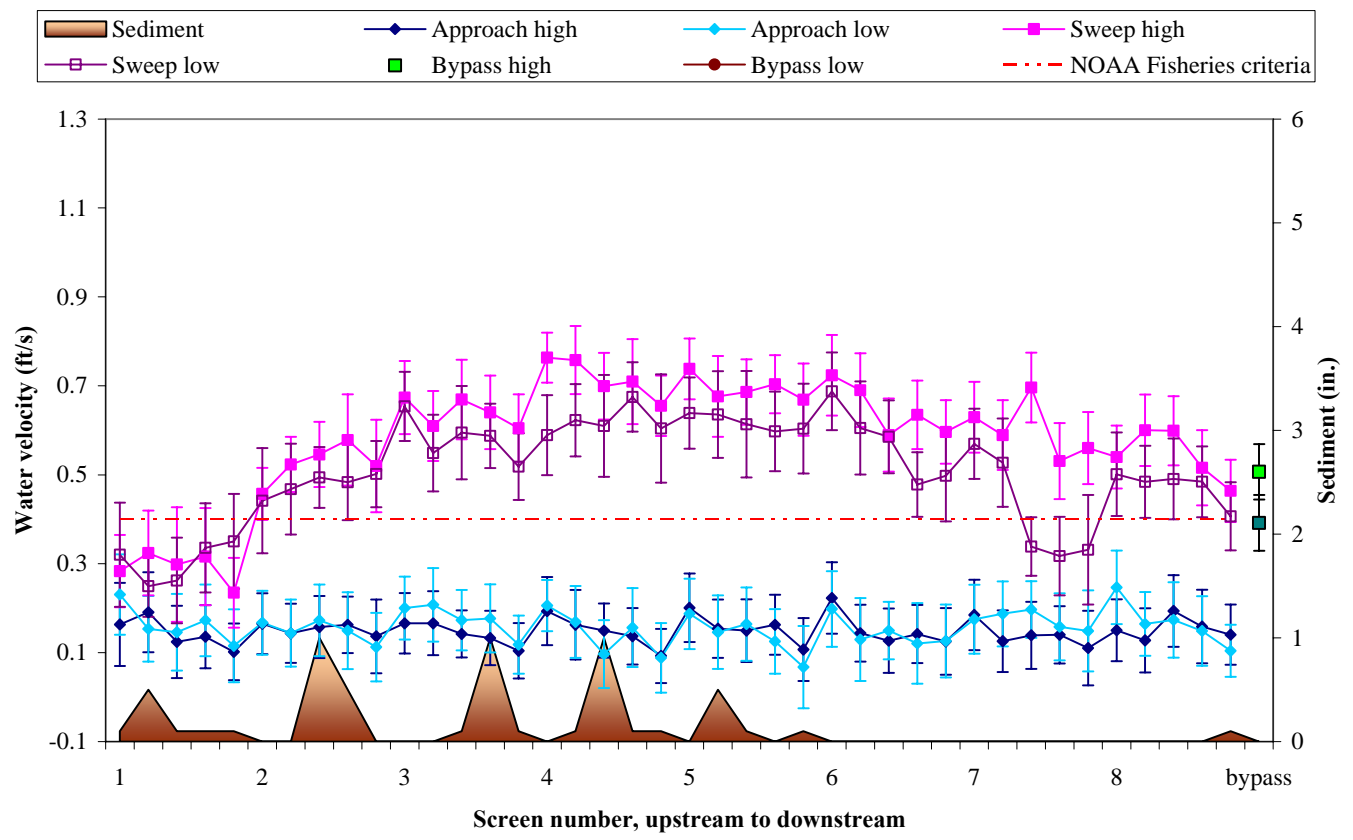

Figure 28. Water velocities and sediment depths at New Cascade in May 2004. Error bars show turbulence ( \pm the root-mean-squared (RMS)) at each point. 
New Cascade - June 28, 2004

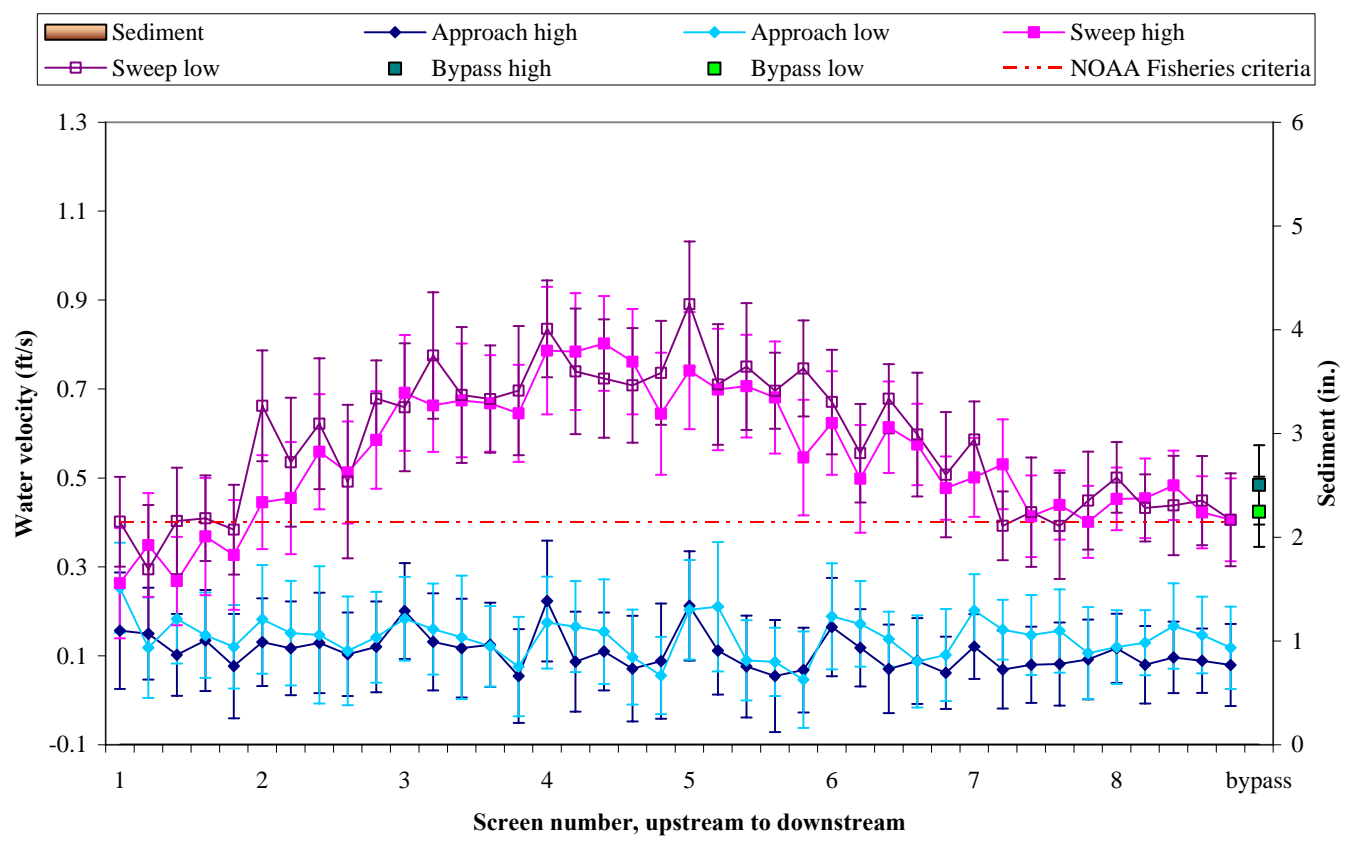

Figure 29. Water velocities and sediment depths at New Cascade in June 2004. Error bars show turbulence ( \pm the root-mean-squared (RMS)) at each point.

New Cascade - Septmeber 27, 2004

\begin{tabular}{|c|c|c|c|}
\hline$\square$ Sediment & $\longrightarrow$ Approach high & $\longrightarrow$ Approach low & $\longrightarrow$ - Sweep high \\
\hline —-Sweep low & ㅁ Bypass high & 口 Bypass low & $-\cdots-$ NOAA Fisheries criteria \\
\hline
\end{tabular}

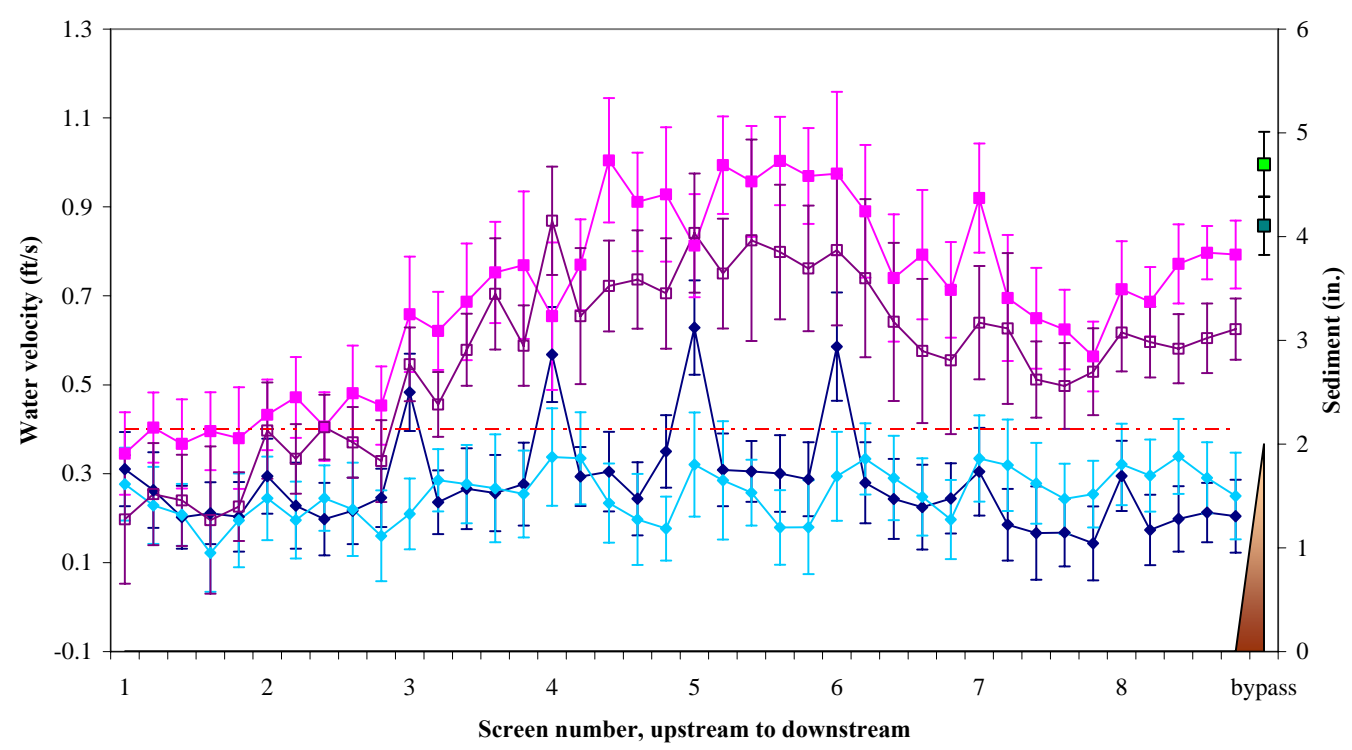

Figure 30. Water velocities and sediment depths at New Cascade in September 2004. Error bars show turbulence ( \pm the root-mean-squared (RMS)) at each point. 


\section{Powell-LaFortune}

Powell-LaFortune was evaluated on May 21, July 1, and September 23, 2004. During all surveys, $100 \%$ of approach velocities met NOAA Fisheries criteria. Sweep velocities were always higher than approach velocities and generally increased towards the bypass in July (Figures 31 through 33). Bypass velocities were greater than the average sweep velocity. Percent submergence met the NOAA Fisheries criteria in May and September at 78\% and 82\%, respectively, but was above the criteria in July at $89 \%$.

In the past, this site has had problems meeting NOAA Fisheries criteria for submergence, but since a wing dam was installed in the river in mid-July of 2003, the submergence values have generally been at the high end of the criteria range to above criteria. The trash racks were much cleaner in 2004 that in past years.

All visible seals were in good condition, as was the screen material. An accumulation of sediment and/or debris covered some of the bottom seals during all surveys. Bypass conditions appeared to be conducive to safe fish passage. During all surveys, water flowed freely over the weir and through the outfall, and water depth in the outfall pipe met NOAA Fisheries criteria.

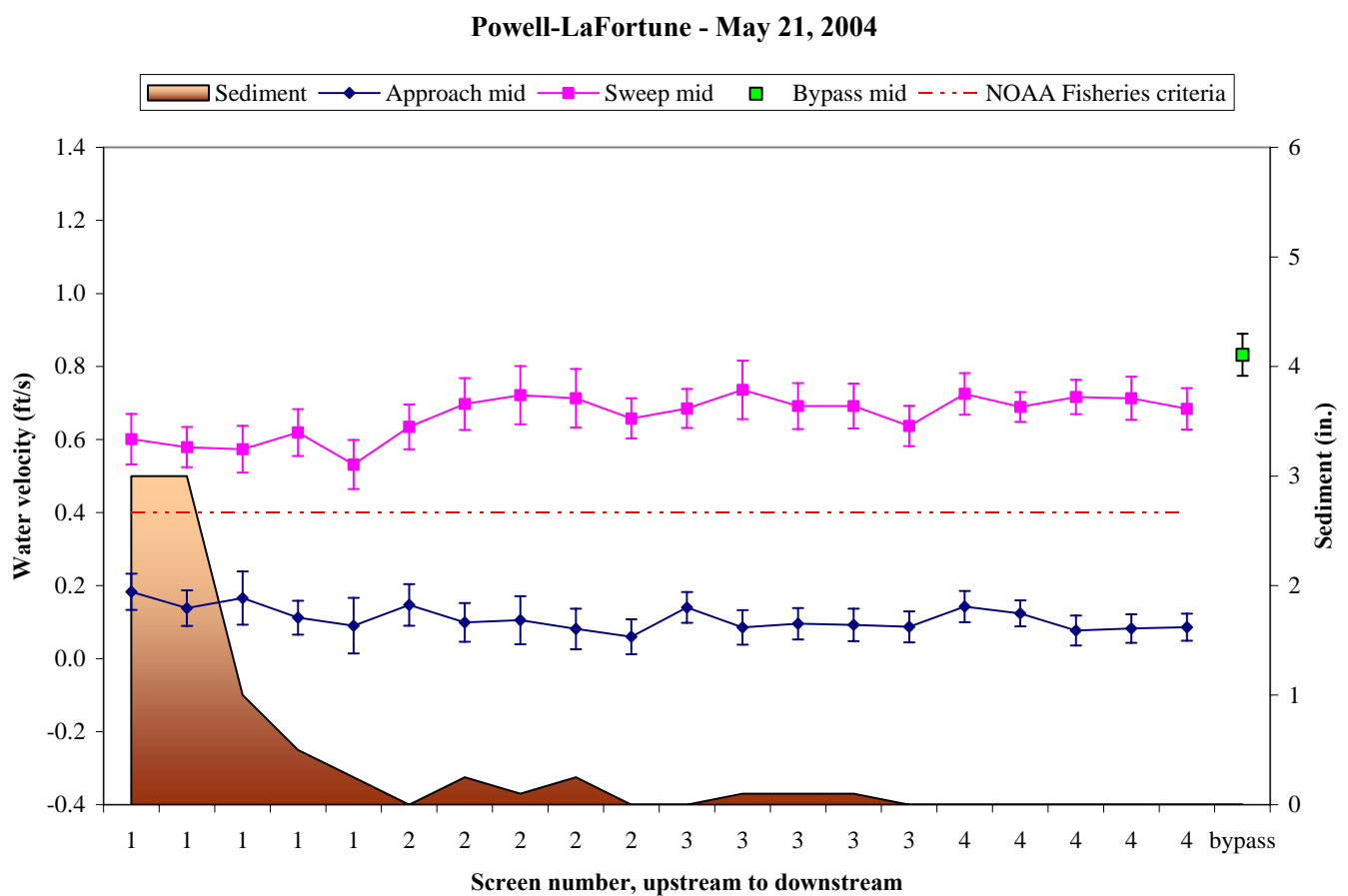

Figure 31. Water velocities and sediment depths at Powell-LaFortune in May 2004. Error bars show turbulence ( \pm the root-mean-squared (RMS)) at each point. 


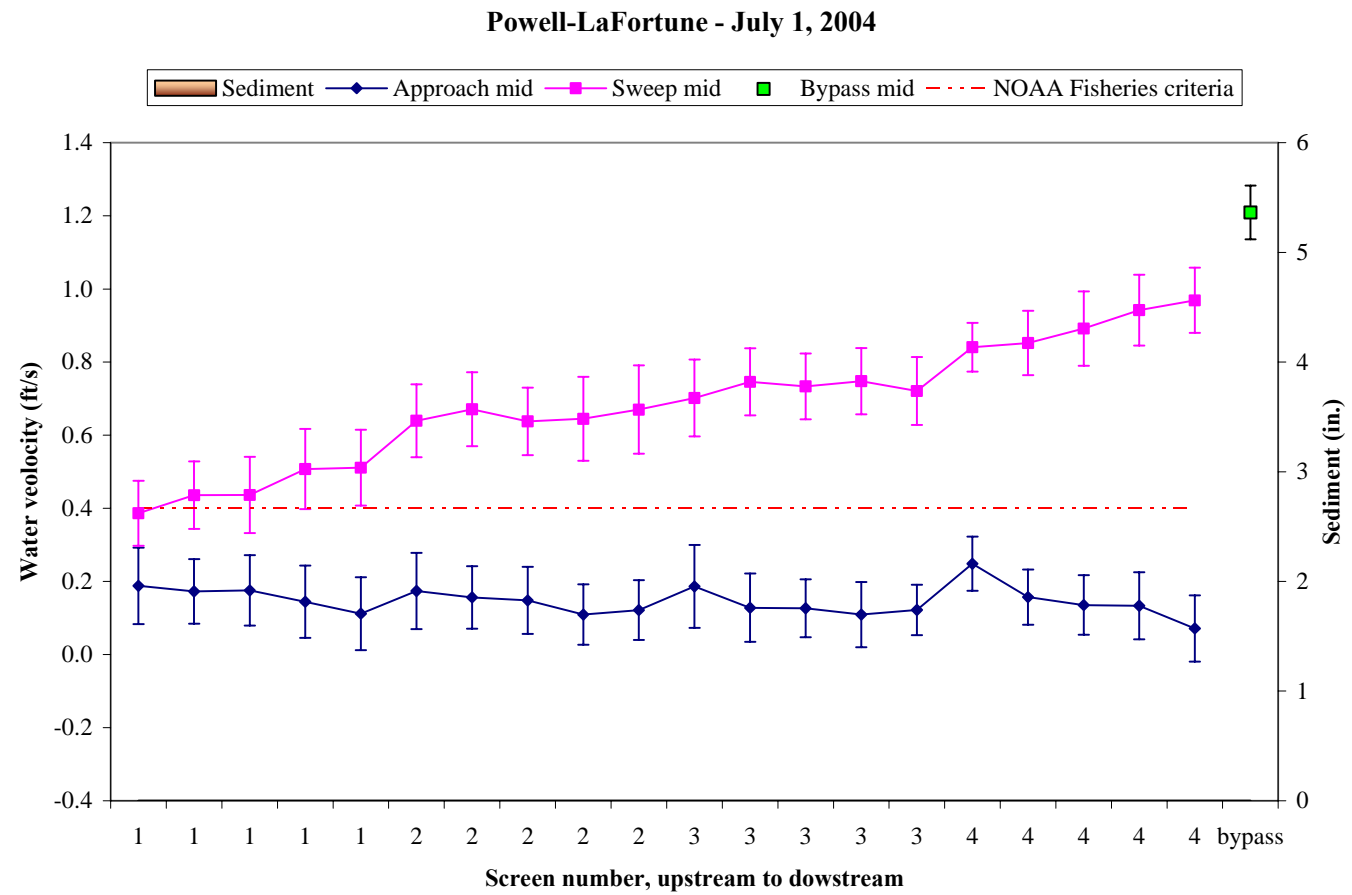

Figure 32. Water velocities and sediment depths at Powell-LaFortune in July 2004. Error bars show turbulence ( \pm the root-mean-squared (RMS)) at each point.

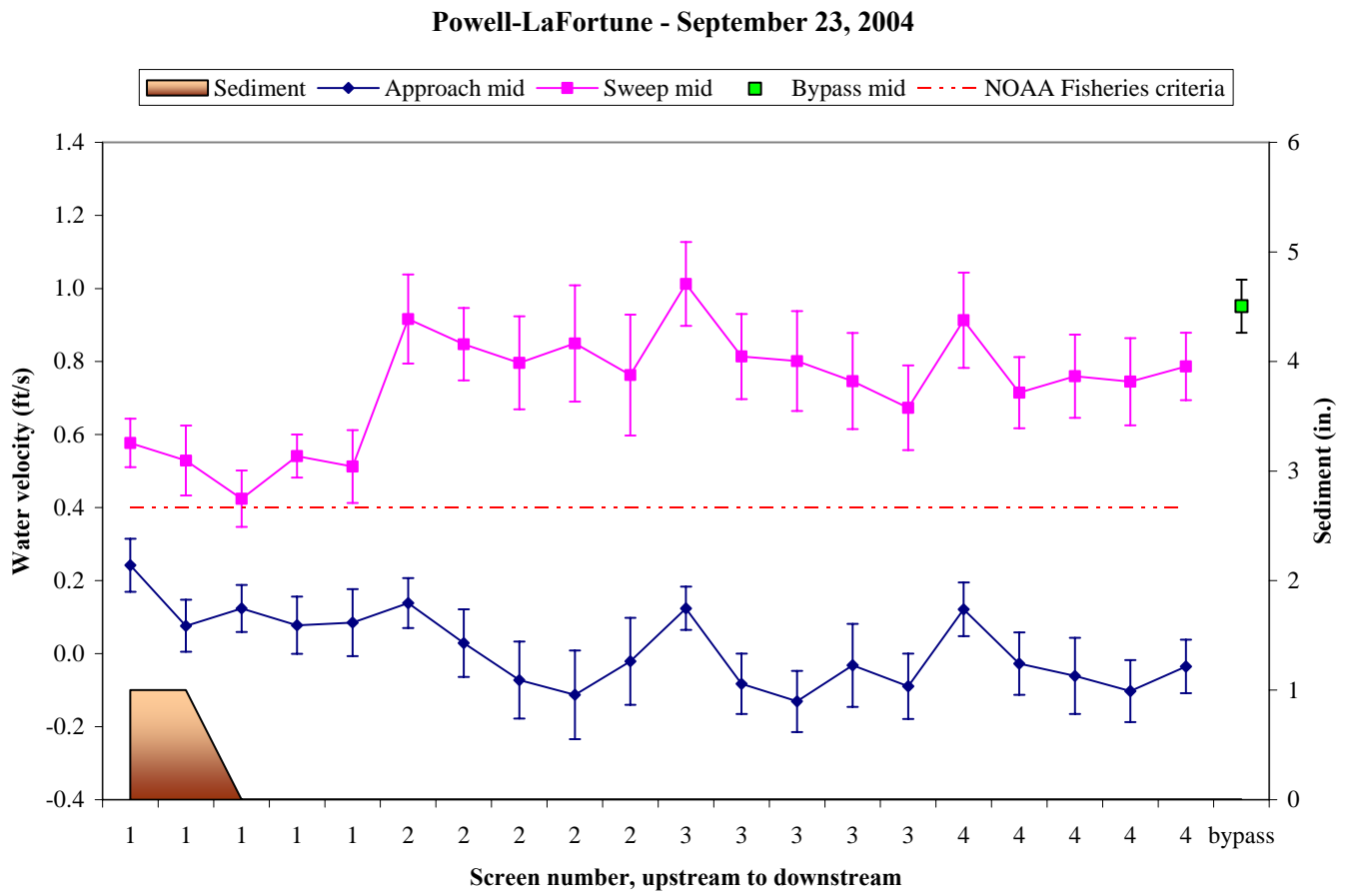

Figure 33. Water velocities and sediment depths at Powell-LaFortune in September 2004. Error bars show turbulence ( \pm the root-mean-squared (RMS)) at each point. 


\section{Snipes-Allen}

The Snipes-Allen site was evaluated on May 18, June 30, and September 21, 2004. All approach velocities met NOAA Fisheries criteria during all surveys (Figures 34 through 36 ). Sweep velocities were generally higher than approach velocities during all surveys, except at the upstream screen in September (Figures 34 through 36). Sweep velocities did not increase towards the bypass except in September, and the average bypass velocity was less than the average sweep velocity in June.

Past problems with debris catching on the trash racks appeared to be resolved in 2004, and the trash racks were generally clean in 2004. Screen submergence met NOAA Fisheries criteria during all surveys (82, 78, and 83\% in May, June, and September, respectively), and there was not an excessive accumulation of debris or plant material. The screens and screen seals at this site were in good condition during all surveys.

Bypass conditions were generally safe for fish passage during all three evaluations. There were no obvious bypass obstructions in 2004, though in June there was a large raft of milfoil that appeared to be stuck in the end of bypass pipe. Ray Gilmour was notified, but by the time he checked the site the milfoil was not there. During our evaluations, water ran freely behind the weir and out the outfall, and water depth at the point of discharge was always greater than $1 \mathrm{ft}$.

Snipes-Allen - May 18, 2004

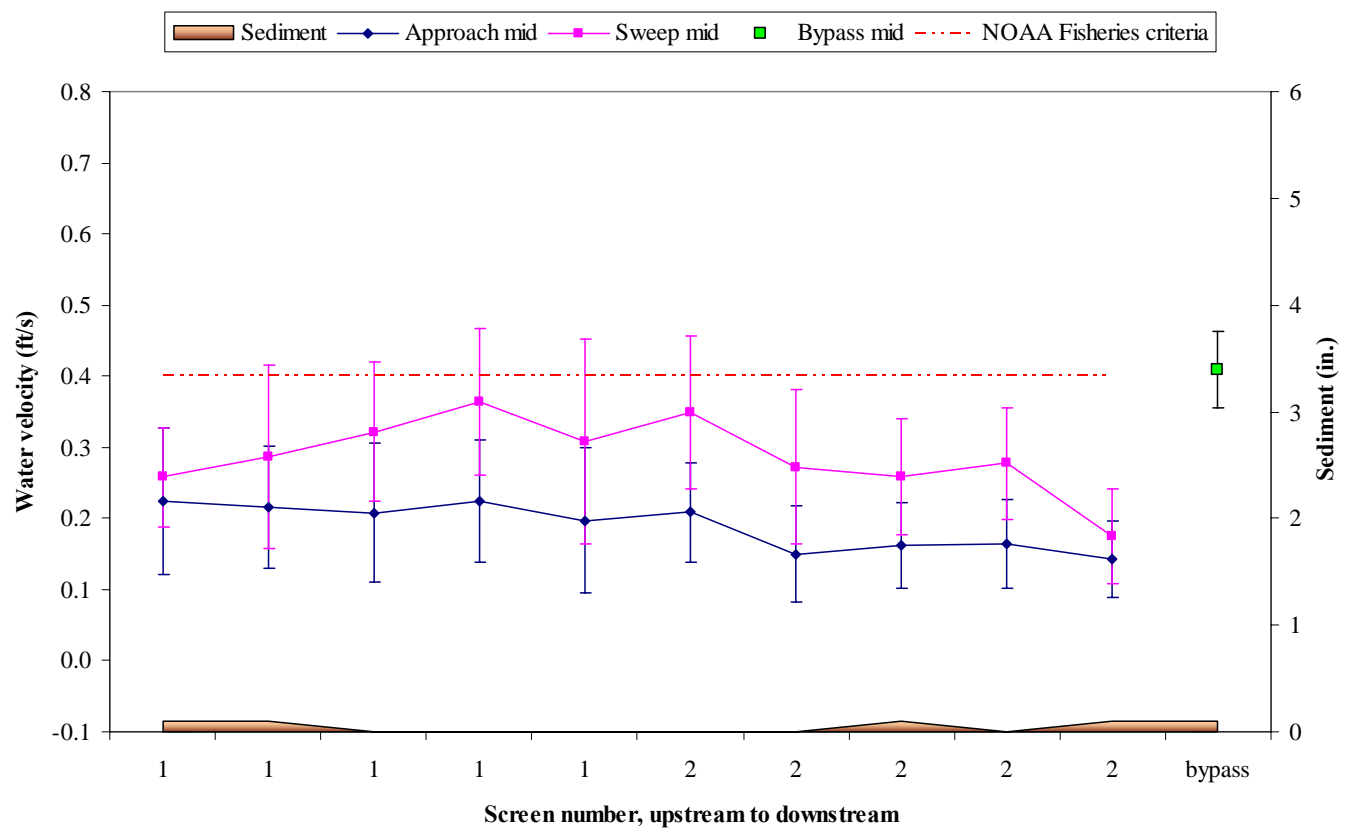

Figure 34. Water velocities and sediment depths at Snipes-Allen in May 2004. Error bars show turbulence ( \pm the root-mean-squared (RMS)) at each point. 
Snipes-Allen - June 30, 2204

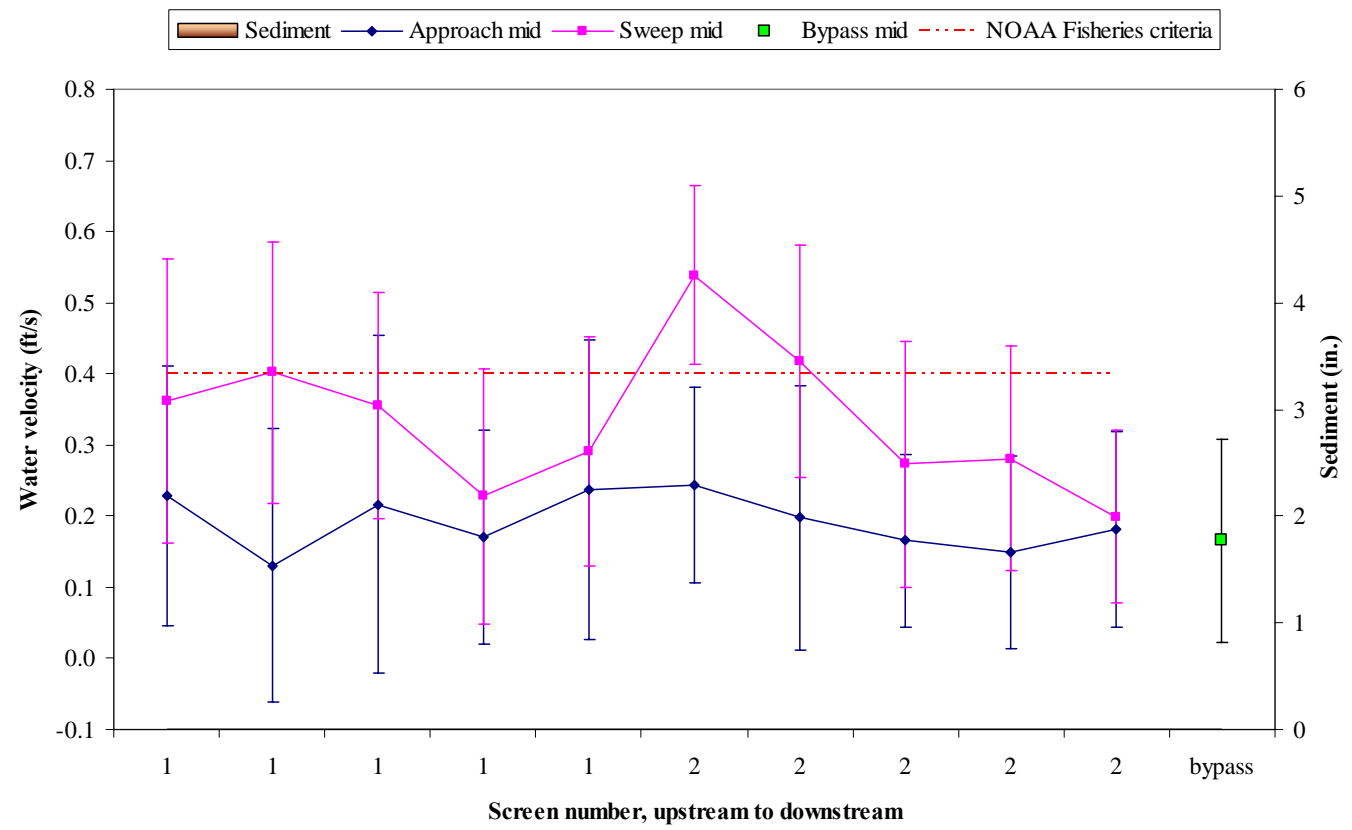

Figure 35. Water velocities and sediment depths at Snipes-Allen in June 2004. Error bars show turbulence ( \pm the root-mean-squared (RMS)) at each point.

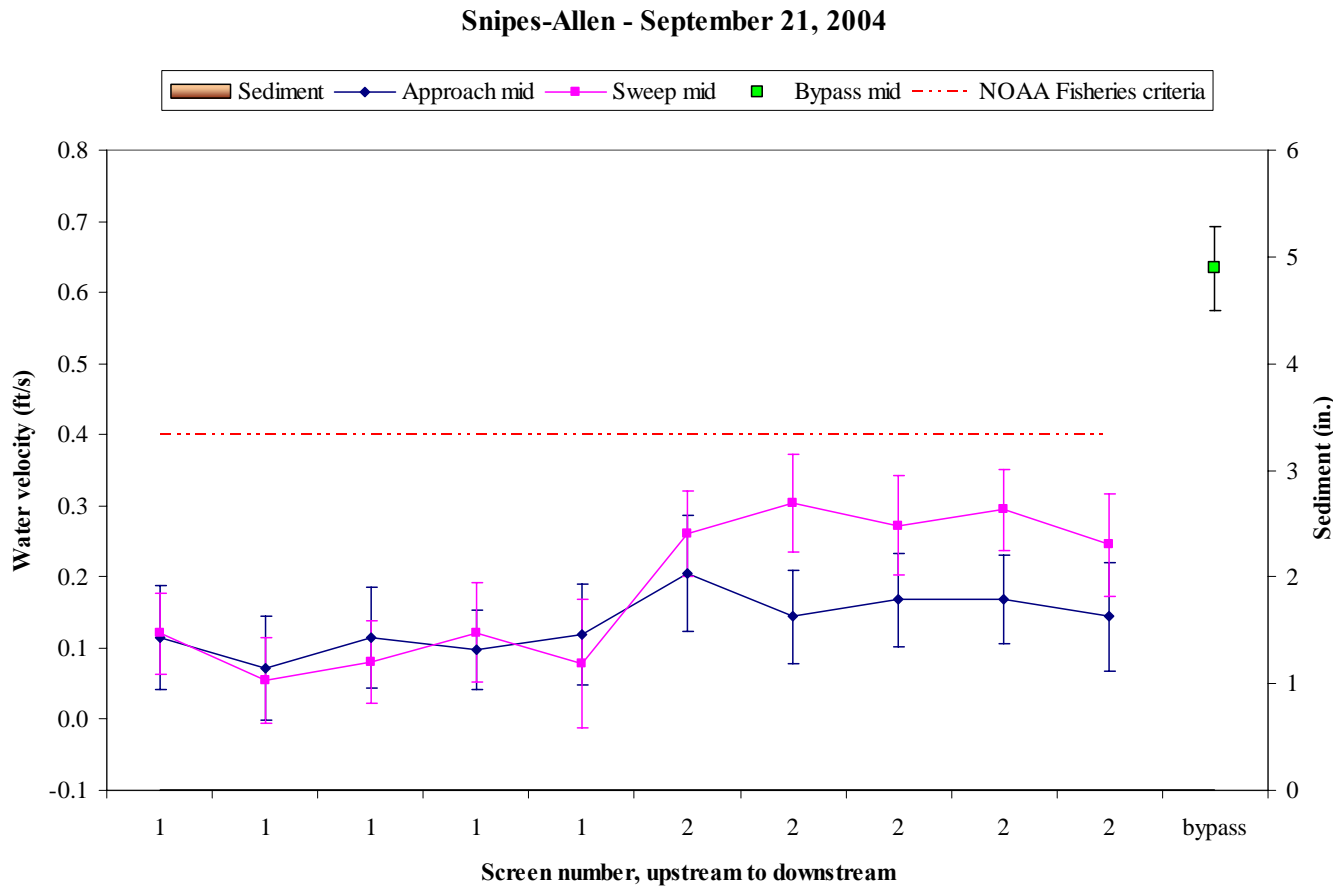

Figure 36. Water velocities and sediment depths at Snipes-Allen in September 2004. Error bars show turbulence ( \pm the root-mean-squared (RMS)) at each point. 


\section{Taylor}

The Taylor site was evaluated on May 19, June 29, and September 22, 2004, although the site was essentially shut down for the season before our September survey. All approach velocities met NOAA Fisheries criteria in May and June (Figures 37 and 38). Sweep velocities were generally greater than approach velocities in May, but the bypass velocity was always less than the average sweep velocity. Percent submergence was below criteria during the survey in May at 50\%. In June submergence met criteria with $80 \%$.

Screen and seal condition appeared to be fine and the gaps between the metal frame of the screens and the cement walls were filled with expanding foam insulation. In June two 12-15” carp were observed in the aftbay. There was never enough river flow to provide water for the bypass, and 1 to 4 inches of water leaked underneath the mostly-closed flushgate during all surveys. In May a dead salmonid fry was stuck under the flushgate. Outfall conditions appeared to meet criteria limits in May though the outfall could not be evaluated in June or September because the area was too overgrown.

This site has had many problems meeting submergence and flow criteria over the past several years. Flows in the stream tend to be inconsistent within the irrigation season, and the main channel has shifted away from the screen site, making it even more difficulty to divert water to the site, especially when flows are low. Notes in the site logbook indicate that submergence fluctuated between $0 \%$ and $80 \%$ between our May and June evaluations. Ray Gilmore was notified on May 12, 2003 of the low submergence, although there was nothing he could do about it because the stream level was low.

Because of the history of problems at this site and the change in stream conditions, we strongly recommend that the design of this site and its diversion be reevaluated and that changes be made to put the site into compliance with the NOAA Fisheries criteria.

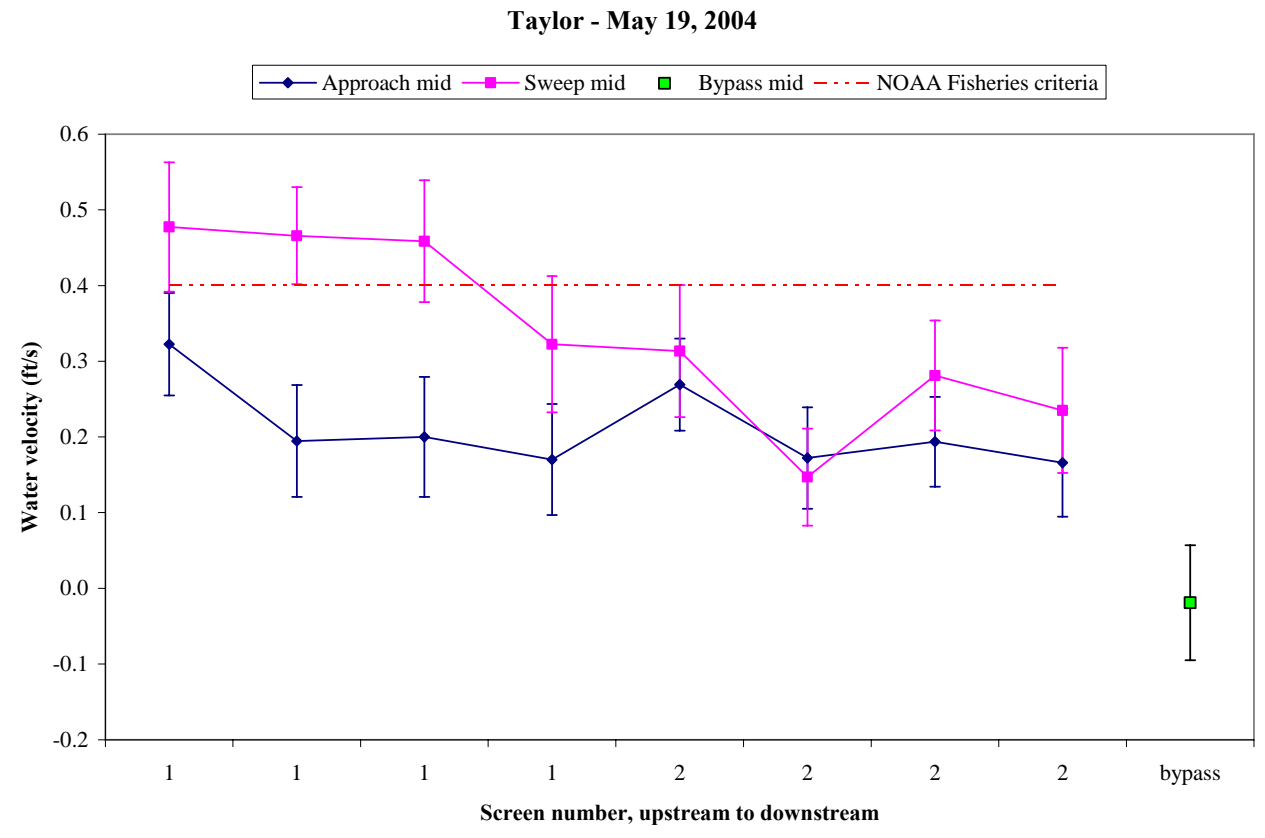

Figure 37. Water velocities and sediment depths at Taylor in May 2004. Error bars show turbulence ( \pm the root-mean-squared (RMS)) at each point. 


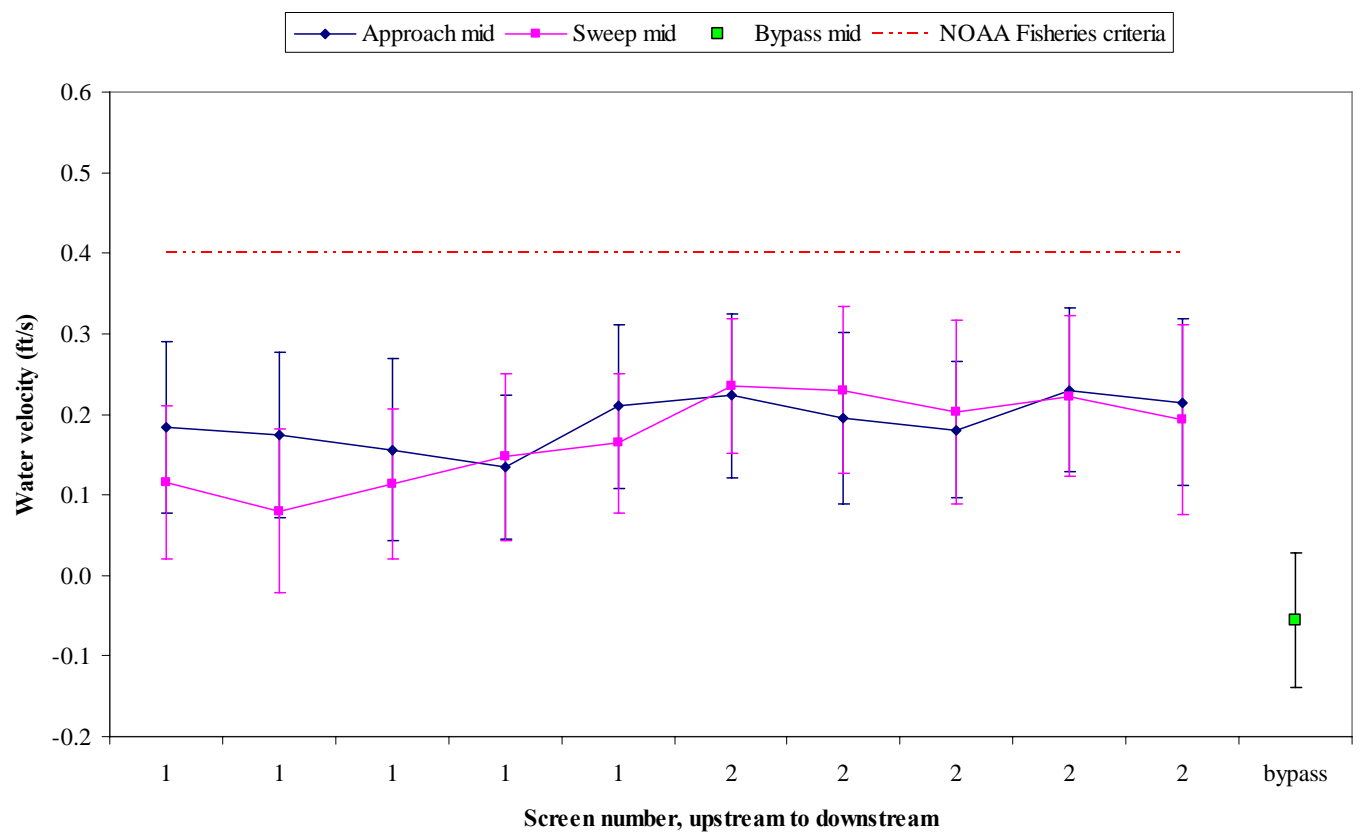

Figure 38. Water velocities and sediment depths at Taylor in June 2004. Error bars show turbulence ( \pm the root-mean-squared (RMS)) at each point.

\section{Toppenish Pump}

The Toppenish Pump site was visited on May 18, June 30, and September 22, 2004. In May, June, and September, 90, 87, and 97\% of approach velocities met NOAA Fisheries criteria, respectively. Jim Rice was notified concerning the high approach velocities on July 6, though we did not receive a response from him. Sweep velocities were generally higher than approach velocities, except in front of screen 1 (Figures 39 through 41). Sweep velocities generally increased towards the bypass, and bypass velocities were always higher than sweep velocities. Submergence was calculated to meet criteria in May, June, and September at 76, 75, and 70\%, respectively.

The screens and visible seals appeared to be in good condition during all surveys. During all surveys, sediment and debris covered some to nearly all of the bottom seals. This site continues to have the worst record in terms of sediment and debris loads near the screens. Since this could potentially wear out the screen motors prematurely as well as create habitat for predators, we recommend that more attention be paid to debris removal throughout the irrigation season. The gaps between the metal frames of the drums and the cement walls of the site were not caulked. Bypass conditions were favorable during all surveys, though there was a small amount of debris floating on the water surface at the outfall. 
Toppenish Pump - May 18, 2004

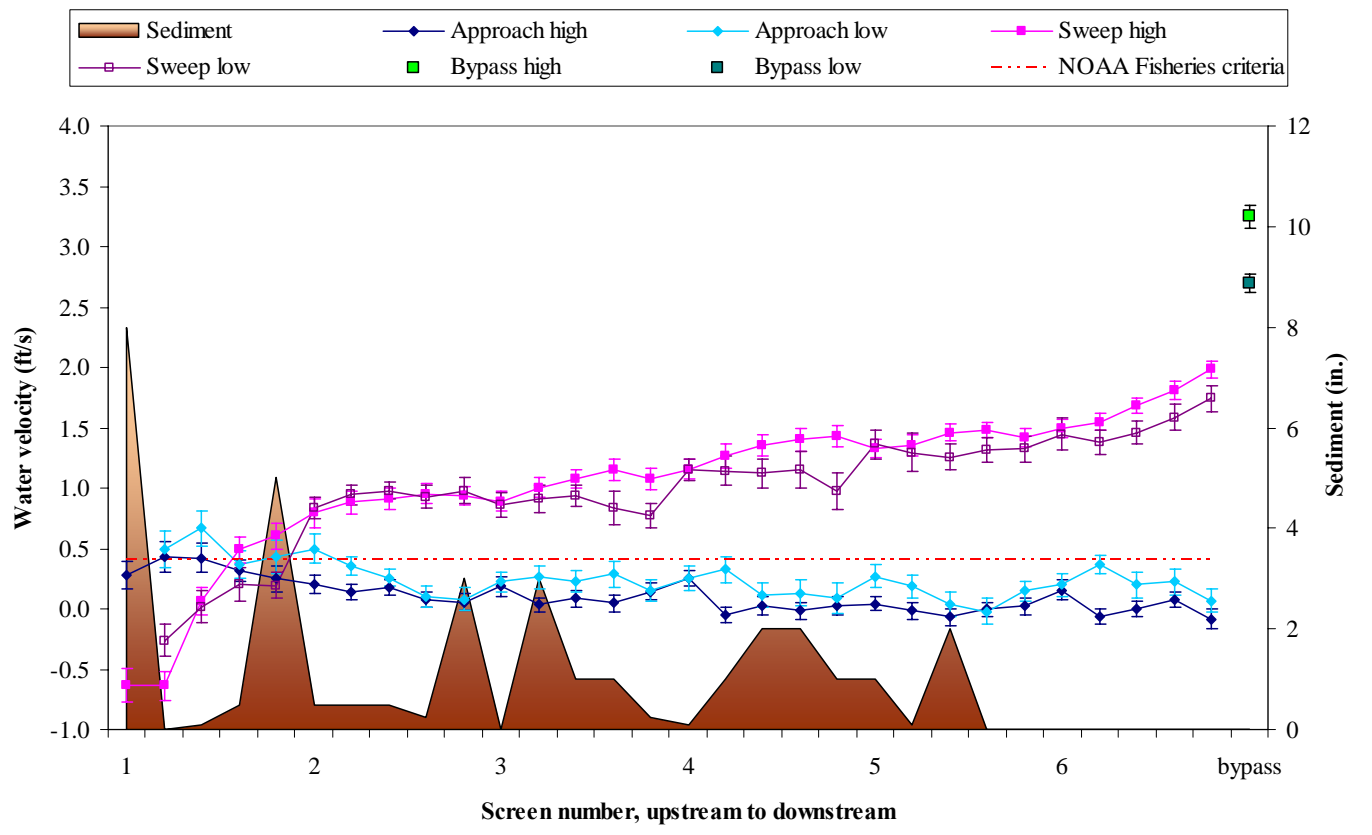

Figure 39. Water velocities and sediment depths at Toppenish Pump in May 2004. Error bars show turbulence ( \pm the root-mean-squared (RMS)) at each point.

Toppenish Pump - June 30, 2004

$\square$ Sediment $\longrightarrow$ - Approach mid $\longrightarrow-$ Sweep mid $\quad \square \quad$ Bypass mid $-\cdots$ NOAA Fisheries criteria

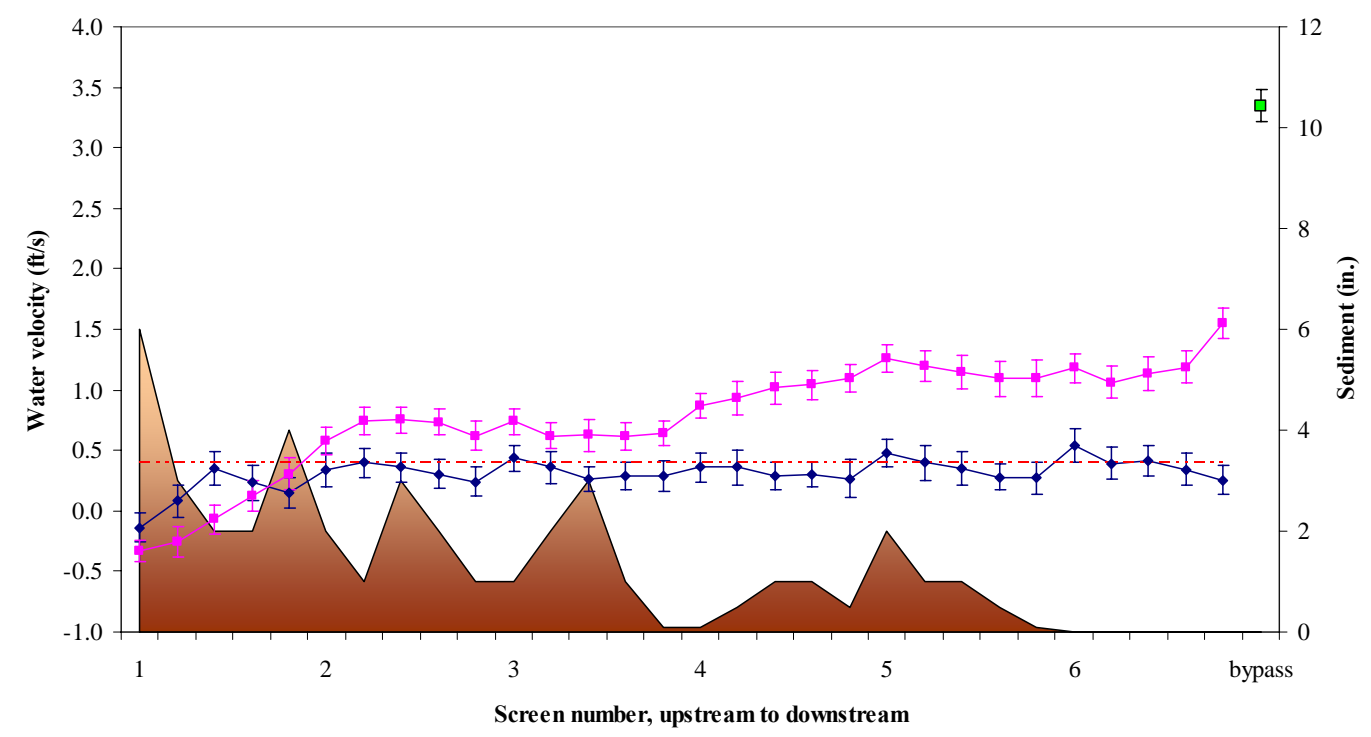

Figure 40. Water velocities and sediment depths at Toppenish Pump in June 2004. Error bars show turbulence ( \pm the root-mean-squared (RMS)) at each point. 


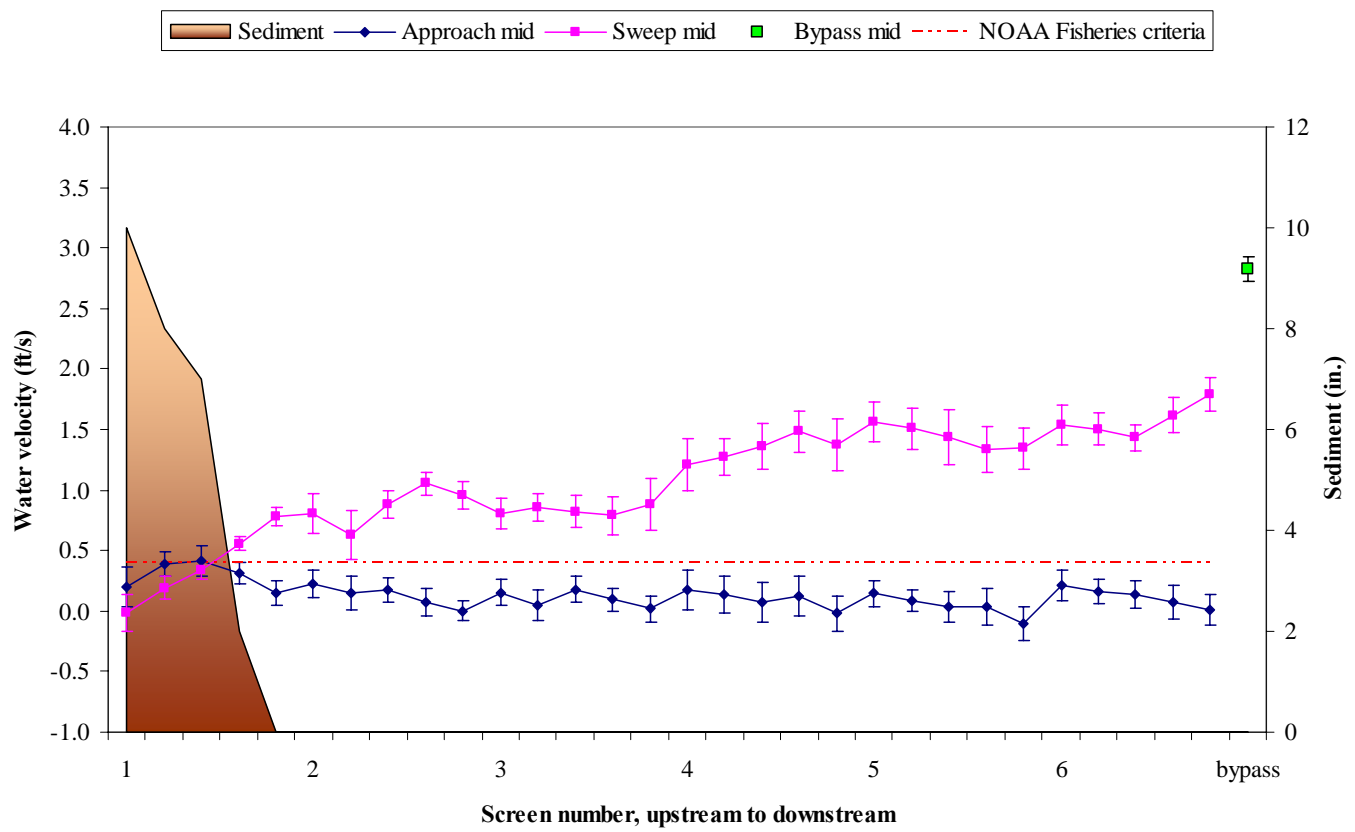

Figure 41. Water velocities and sediment depths at Toppenish Pump in September 2004. Error bars show turbulence ( \pm the root-mean-squared (RMS)) at each point.

\section{Upper Wapato Irrigation Project (WIP)}

The Upper WIP site was visited on May 26, June 23, and September 21, 2004. The site was shut down for the season before the survey in September. All measured approach velocities met NOAA Fisheries criteria in May and June (Figures 42 and 43). In May, sweep velocities were much more turbulent than approach velocities. Sweep velocities did not increase towards the bypass, and the bypass velocity was only slightly greater than the average sweep velocity in May.

Screen submergence met NOAA Fisheries criteria at $82 \%$ submergence in May and was low in June at 55\% submergence. Water flow into the site had been decreased shortly before PNNL staff arrived in June in an effort to resolve water use complaints. Jim Rice was notified on June 23 concerning the low submergence, though we did not receive a response from him. The warps in the screens seals observed in 2003 were still present in 2004, and were probably more pronounced (Figure 44). Bypass conditions were generally good in May and June. Water ran freely behind the weir and out the outfall. The water depth at the point of discharge was greater than 12 in. in May and June, which satisfied NOAA Fisheries criteria and should be expected to provide sufficient water to allow for safe fish passage.

The gaps between the metal frames of the drums and the cement walls of the forebay were not caulked. We recommend that these be filled with expanding foam insulation to prevent harm to migrating fish. 


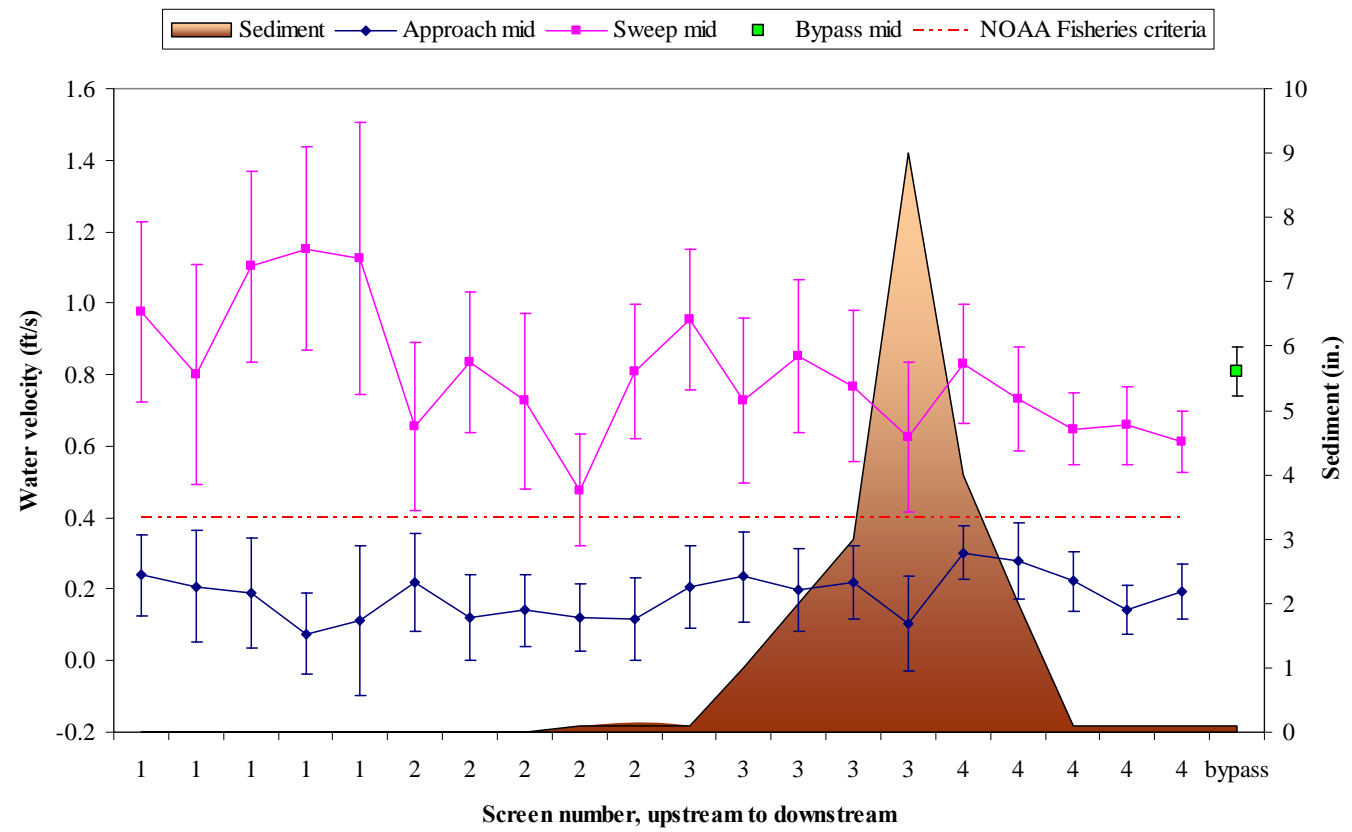

Figure 42. Water velocities and sediment depths at Upper Wapato Irrigation Project (WIP) in May 2004. Error bars show turbulence ( \pm the root-mean-squared (RMS)) at each point.

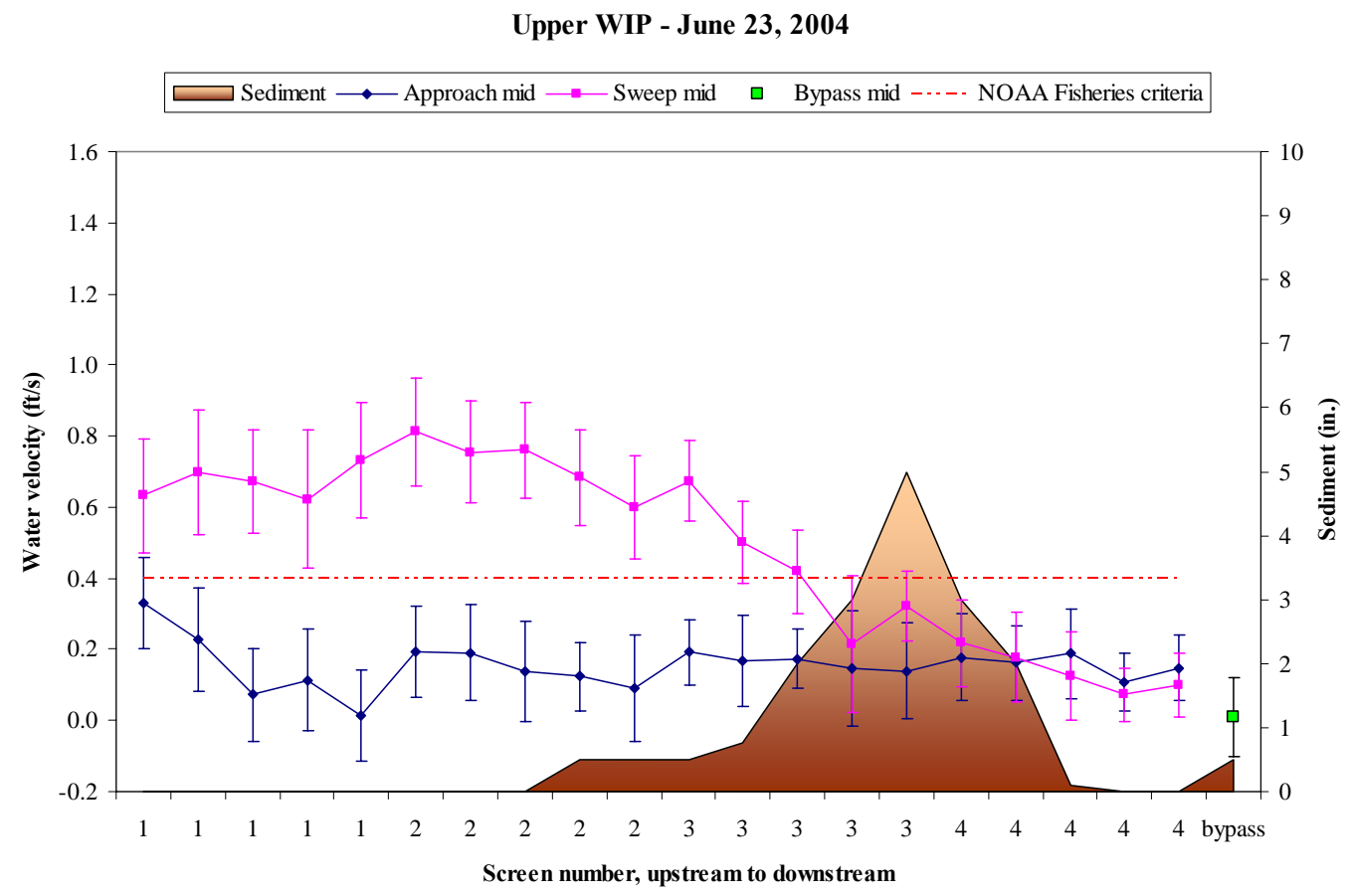

Figure 43. Water velocities and sediment depths at Upper Wapato Irrigation Project (WIP) in June 2004. Error bars show turbulence ( \pm the root-mean-squared (RMS)) at each point. 


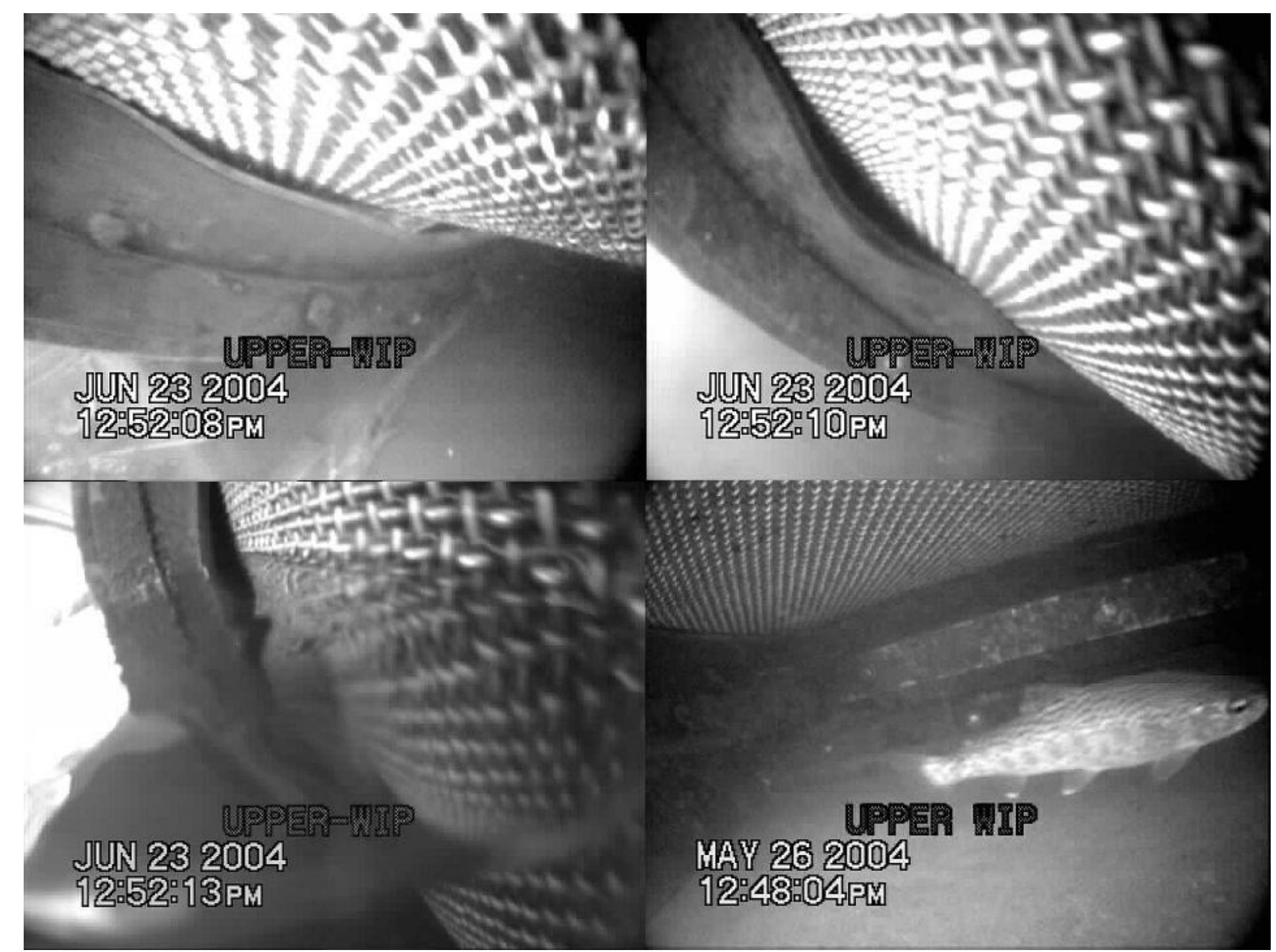

Figure 44. Underwater video pictures from Upper WIP in May and June. The lower right shows a rainbow trout in front of the screens. The other three panels show various warps of the screen seals. The top right picture shows a warp that could potentially pass fish. 


\section{Wilson Creek}

The Wilson Creek site was visited on May 27, June 28, and September 27, 2004. All measured approach velocities met NOAA Fisheries criteria during all surveys (Figures 45 through 47). Sweep velocities were always greater than approach velocities. Sweep velocities did not increase towards the bypass, and the average bypass velocity was slower than the average sweep velocity in September.

Submergence met criteria during all surveys with 77\% in May and September and $81 \%$ in June. The screen material was in good condition during all surveys, as were all seals. The gaps between the metal frames of the drums and the concrete walls of the forebay were filled with expanding foam insulation to prevent harm to migrating fish.

Drums turned freely and evenly during all surveys and rolled leaf matter into the aftbay. Bypass conditions were safe for fish passage during all surveys. Water flowed freely over the weir and out the outfall. The outfall pipe was submerged during all surveys and the depth at the point of discharge was greater than $1 \mathrm{ft}$. In September there was a lot of milfoil on the trash rack.

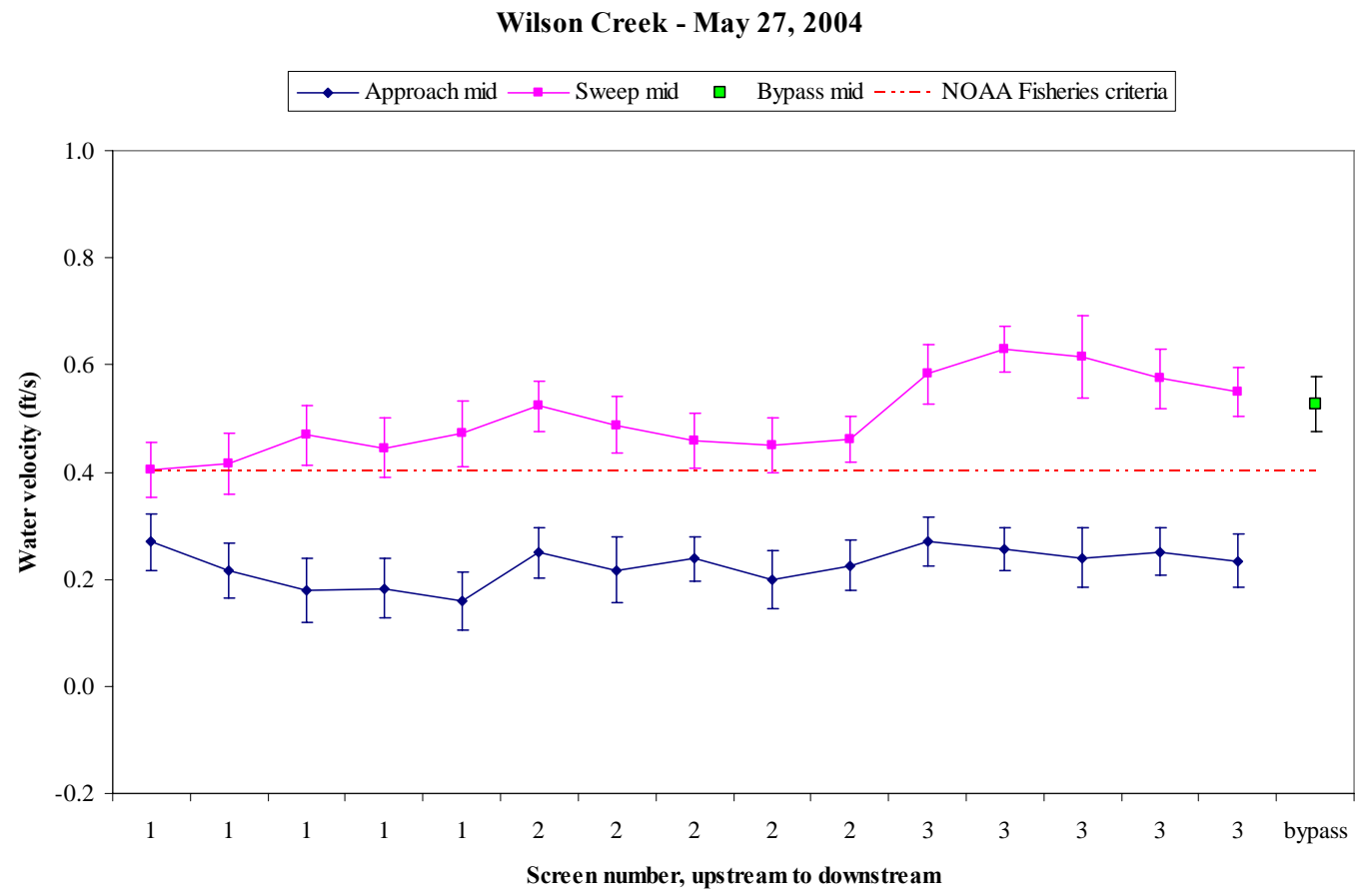

Figure 45. Water velocities and sediment depths at Wilson Creek in May 2004. Error bars show turbulence ( \pm the root-mean-squared (RMS)) at each point. 
Wilson Creek - June 29, 2004

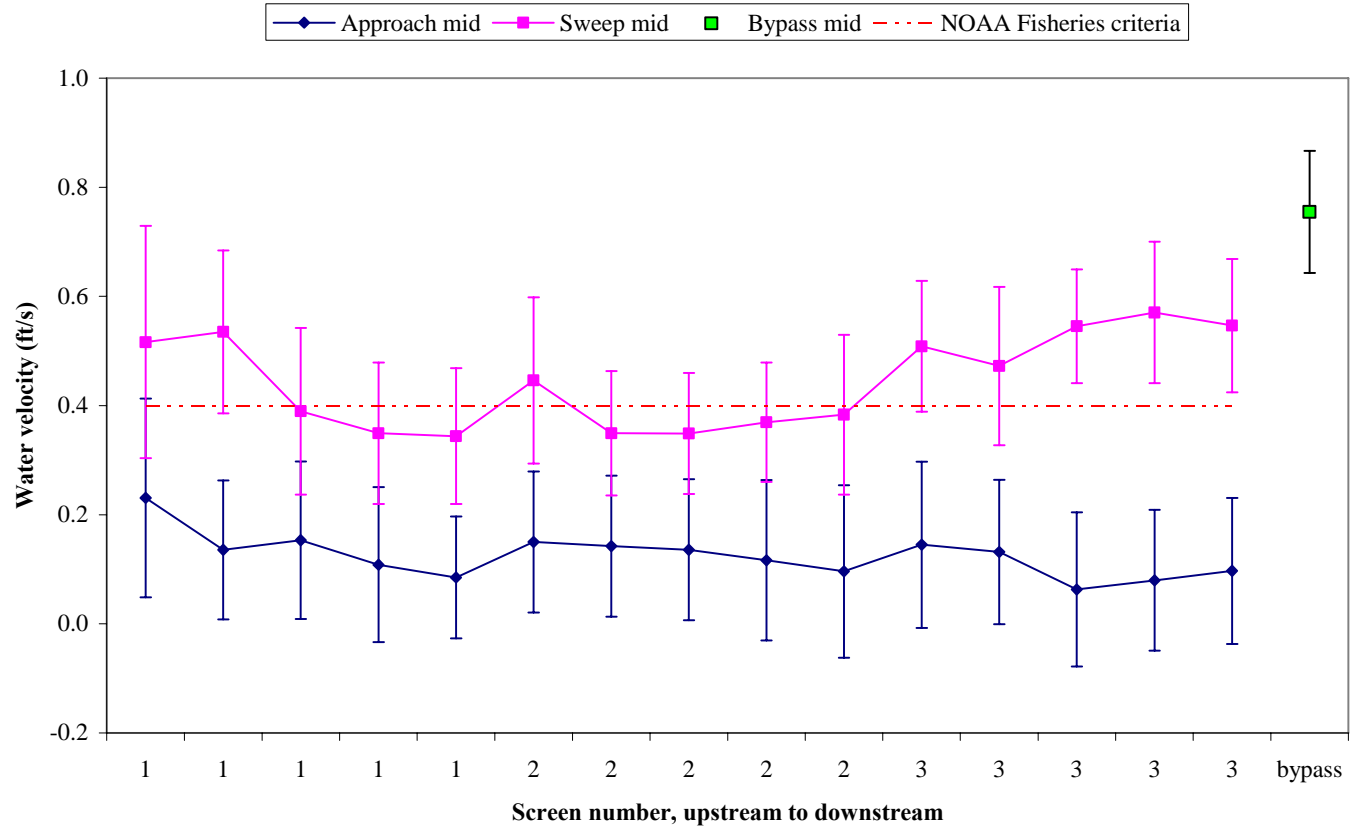

Figure 46. Water velocities and sediment depths at Wilson Creek in June 2004. Error bars show turbulence ( \pm the root-mean-squared (RMS)) at each point.

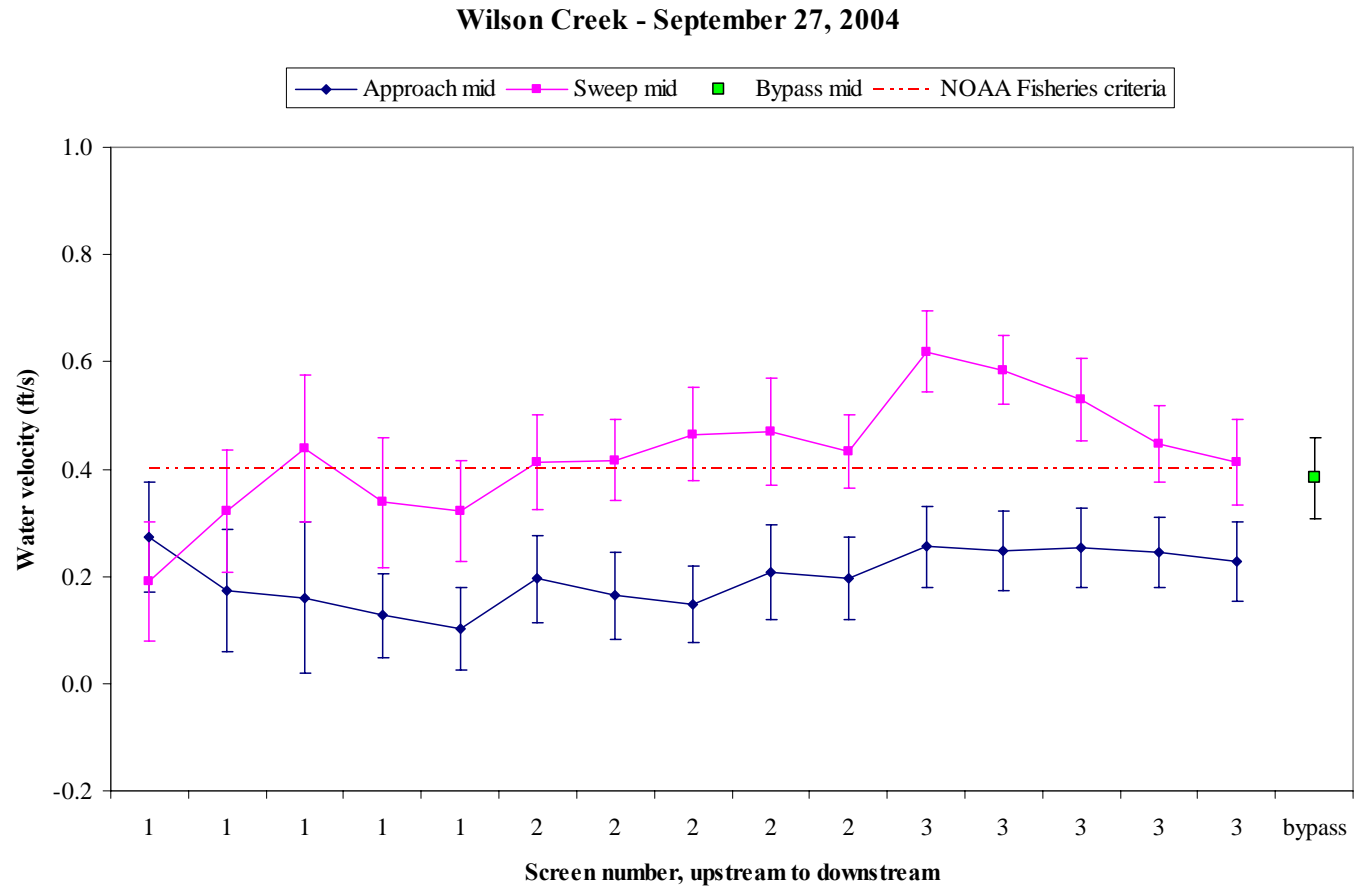

Figure 47. Water velocities and sediment depths at Wilson Creek in September 2004. Error bars show turbulence ( \pm the root-mean-squared (RMS)) at each point. 


\subsection{Vertical Plate Screens}

\section{Bull Ditch}

The Bull Ditch site was evaluated on May 26 and June 28, 2004; the site was permanently removed on September 16, 2004. Sweep velocities were generally higher than approach velocities in June but not in May (Figures 48 and 49). Approach velocities met NOAA Fisheries criteria $93 \%$ and $100 \%$ of the time in May and June, respectively. Sweep velocities tended to decrease over the length of the site, and in May both sweep and approach velocities at the downstream end of the site were approximately zero.

All screens and seals appeared to be in good condition during the surveys. In May sediment and debris buildup at the downstream end of the site prevented a low position velocity measurement. The brushes operated effectively to remove debris from the screen face except the downstream-most brush in May.

Bull Ditch - May 24, 2004

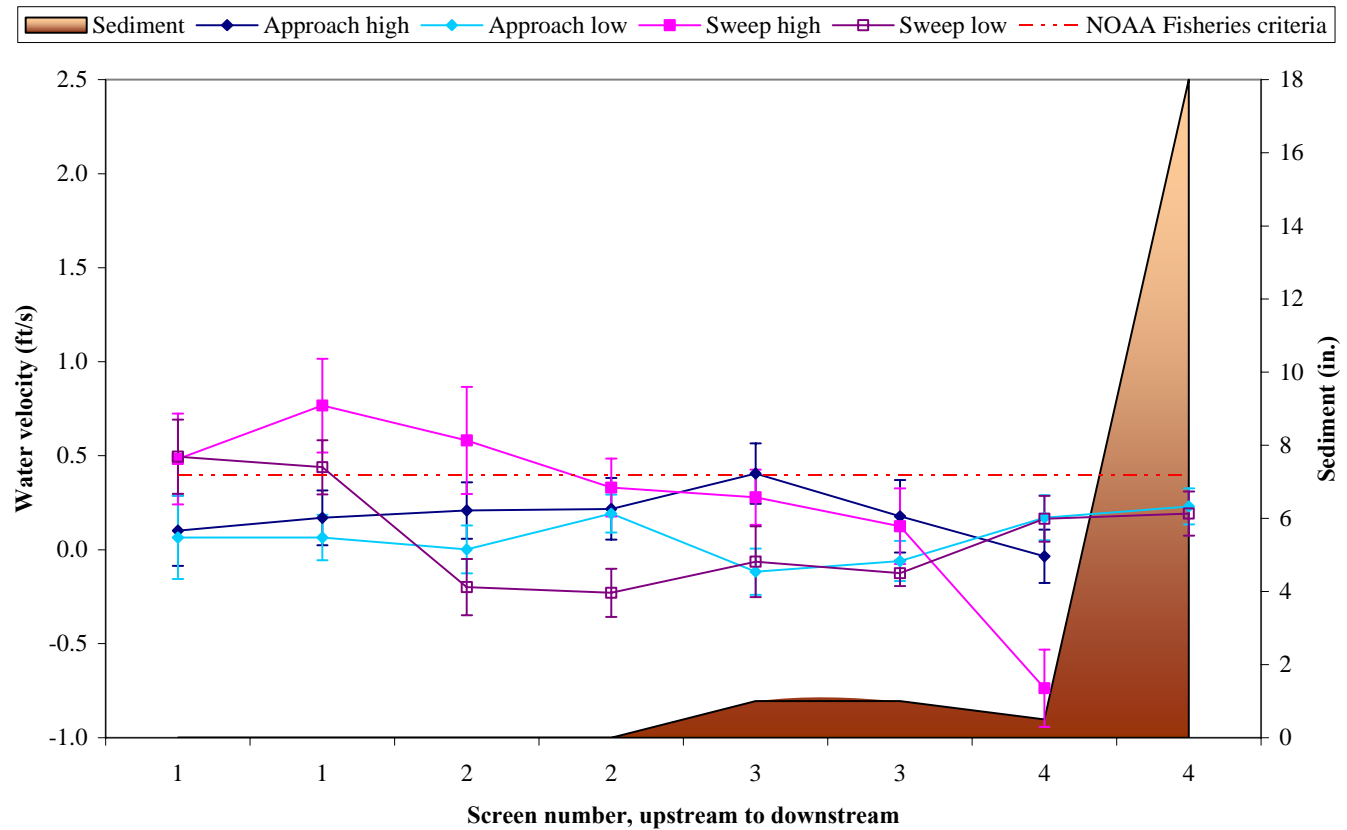

Figure 48. Water velocities and sediment depths at Bull Ditch in May 2004. Error bars show turbulence ( \pm the root-mean-squared (RMS)) at each point. 
Bull Ditch - June 28, 2004

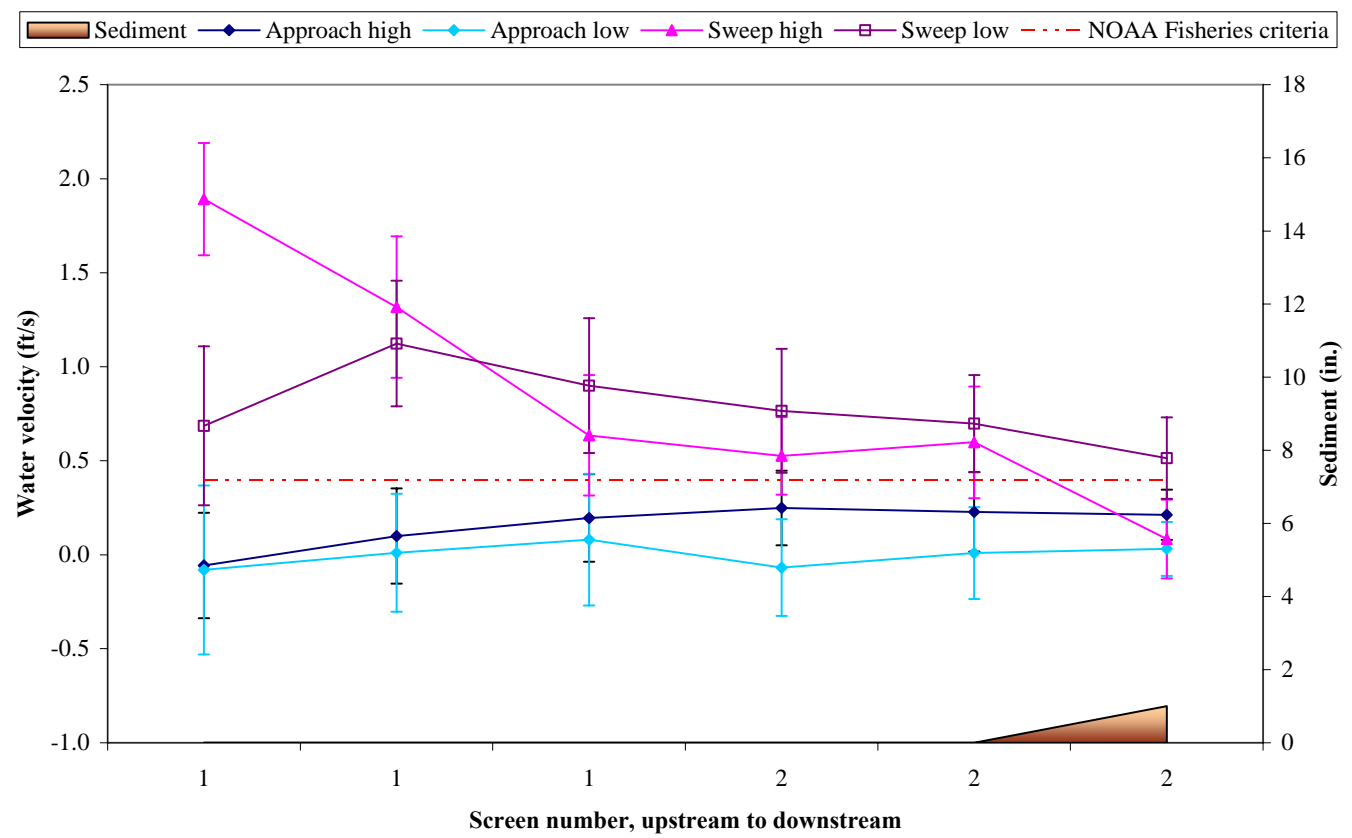

Figure 49. Water velocities and sediment depths at Bull Ditch in June 2004. Error bars show turbulence ( \pm the root-mean-squared (RMS)) at each point.

\section{Ellensburg Mill}

The Ellensburg Mill site was visited on May 24, June 28, and September 27, 2004. Because of aquatic vegetation growth in the forebay, the Marsh-McBirney $511^{\circledR}$ flow meter was used to measure velocity at the low position in May; consequently, turbulence values are not available for those measurements. All approach velocities met NOAA Fisheries criteria during all surveys (Figures 50 through 52). Sweep velocities were generally higher than approach velocities. Sweep velocities did not increase towards the bypass, although the average bypass velocity was greater than the average sweep velocity during all surveys.

The screens appeared to be in good condition during all surveys, but the seals between the screens were partially missing and may need to be replaced. The mechanical brushes effectively removed large debris from most of the screen surfaces, though in September the screens were covered with algae and it was difficult to tell where one stopped and the next began. 
Ellensburg Mill - May 24, 2004

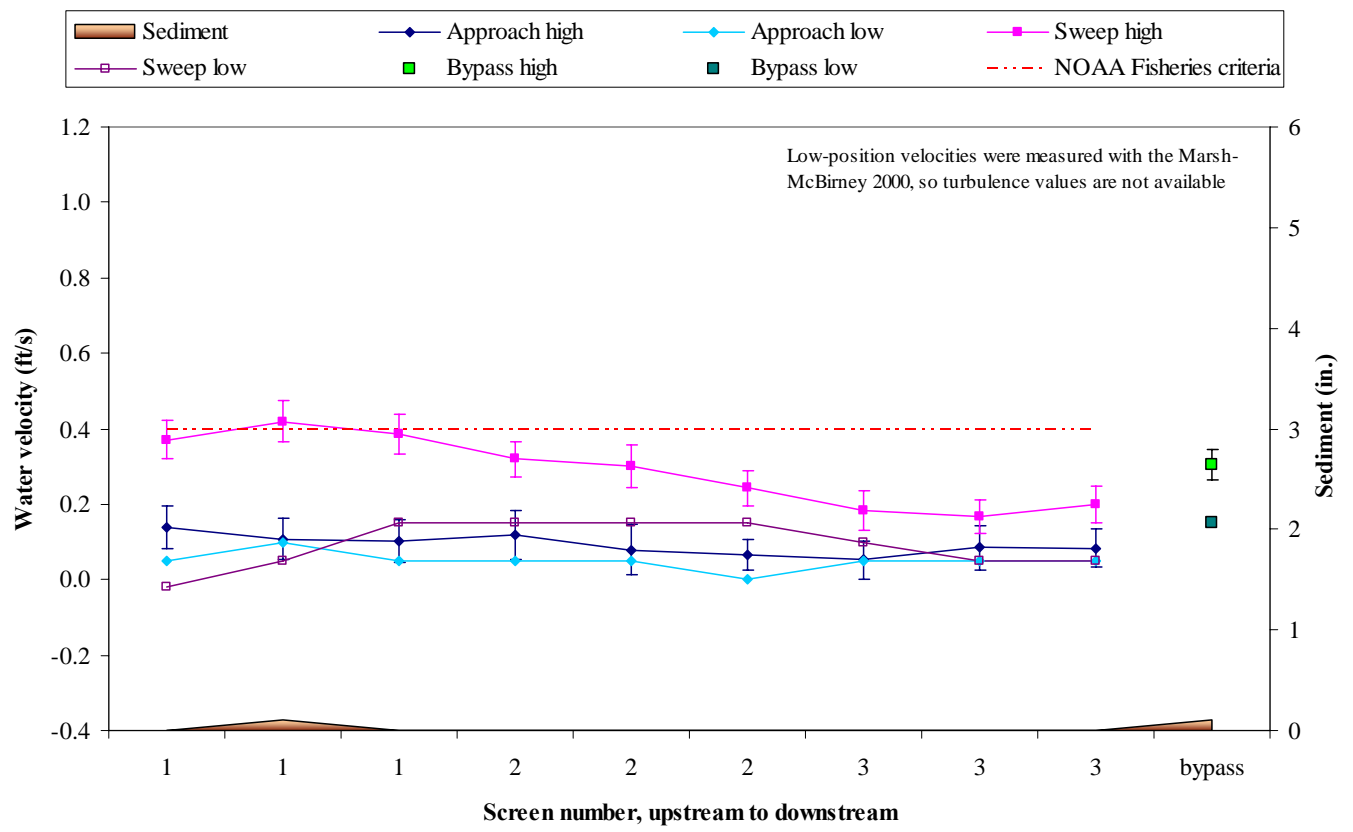

Figure 50. Water velocities and sediment depths at Ellensburg Mill in May 2004. Error bars show turbulence ( \pm the root-mean-squared (RMS)) at each point.

Ellensburg Mill - June 28, 2004

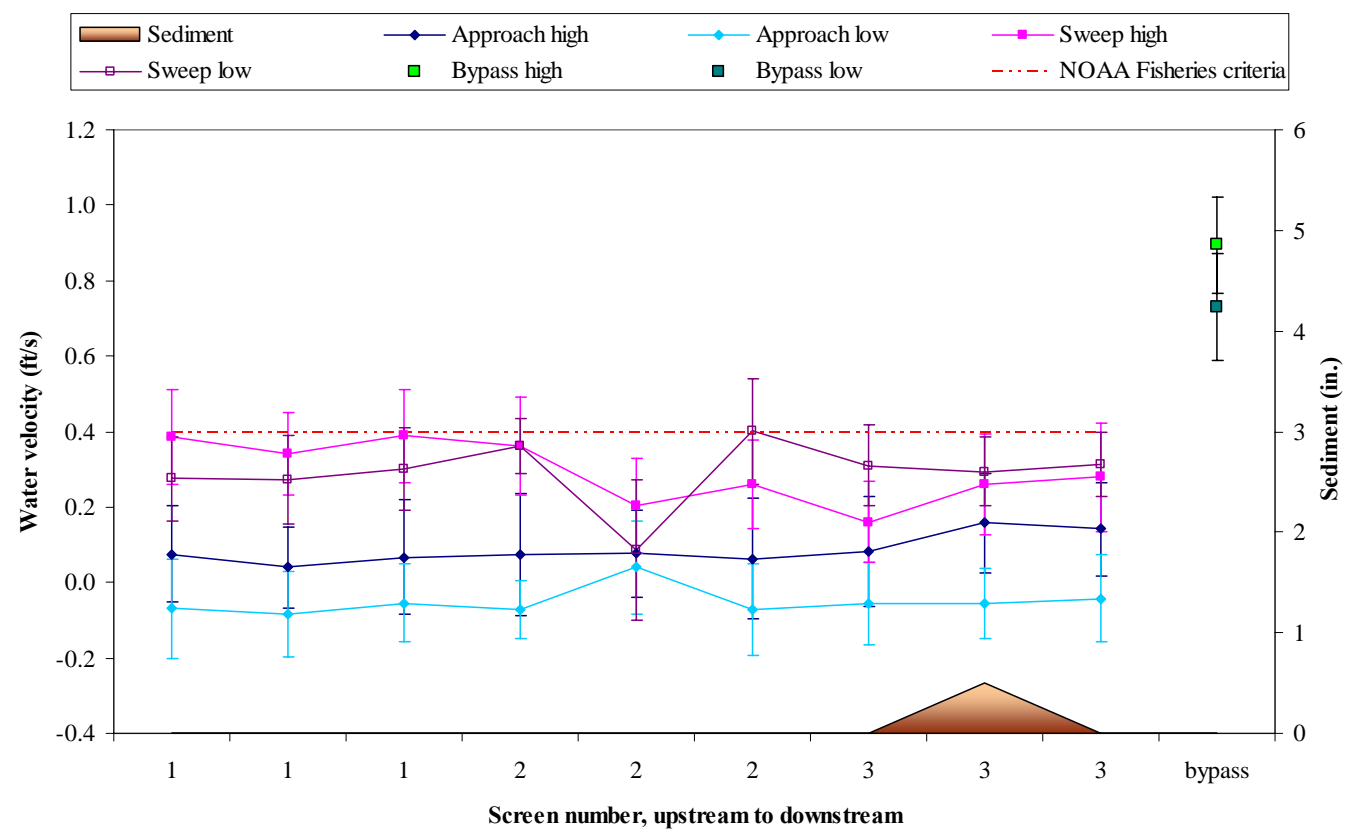

Figure 51. Water velocities and sediment depths at Ellensburg Mill in June 2004. Error bars show turbulence ( \pm the root-mean-squared (RMS)) at each point. 


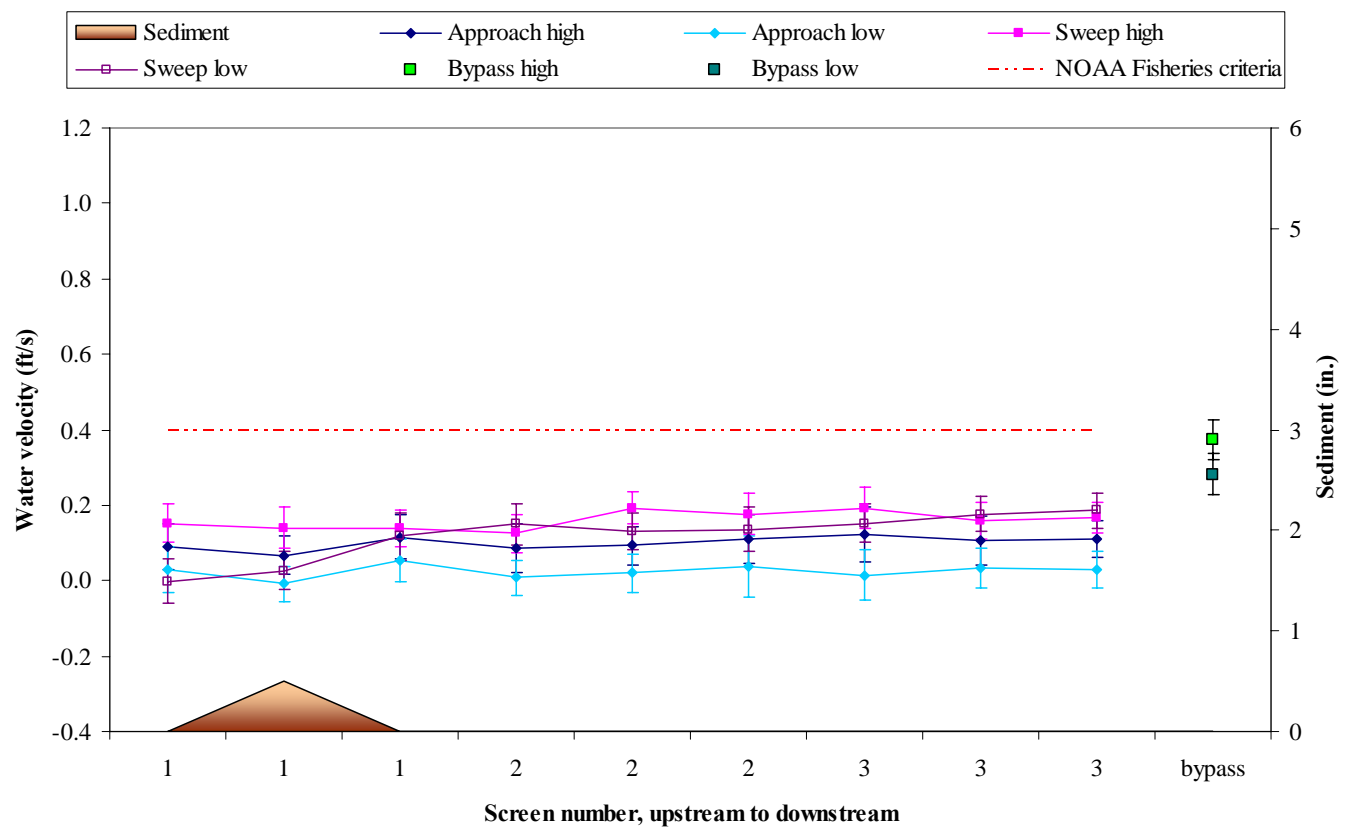

Figure 52. Water velocities and sediment depths at Ellensburg Mill in September 2004. Error bars show turbulence ( \pm the root-mean-squared (RMS)) at each point.

\section{Fruitvale}

The Fruitvale site was visited on May 19, June 22, and September 23, 2004. During all surveys, $100 \%$ of approach velocities met NOAA Fisheries criteria (Figures 53 through 55). Sweep velocities were always higher than approach velocities and generally increased towards the bypass. Bypass velocities were higher than the average sweep velocity during all surveys.

During all surveys, water ran freely over the weir and out the outfall, and outfall conditions met NOAA Fisheries criteria for safe fish passage. However, notes in the logbook indicated that on July 13 and August 2 there was not enough water for spill over the bypass ramp, and the ramp and flushgate were closed. Over the last several years this site has had difficulty maintaining bypass flow during July and August. Salmonid smolts are not expected to migrate during this period, and as long as there is enough water movement to maintain oxygen levels in the water, the flow conditions would not be expected to be a problem. However, because this problem seems to be persistent and has been shown to affect some fish, we recommend that operating conditions be modified to allow fish passage through the bypass during these low flow periods.

The pile of sediment in the aftbay observed in 2003 was removed sometime before the 2004 season, and the level of sediment accumulation in the forebay was reasonable during all surveys. The mechanical brushes operated effectively to remove debris from the screens during all surveys. The screens appeared to be in good condition, although the seals on the upper parts of the screens appeared somewhat weathered, and the video survey revealed that the caulking along the bottom of the screens was loose or missing in places. 
Fruitvale - May 19, 2004

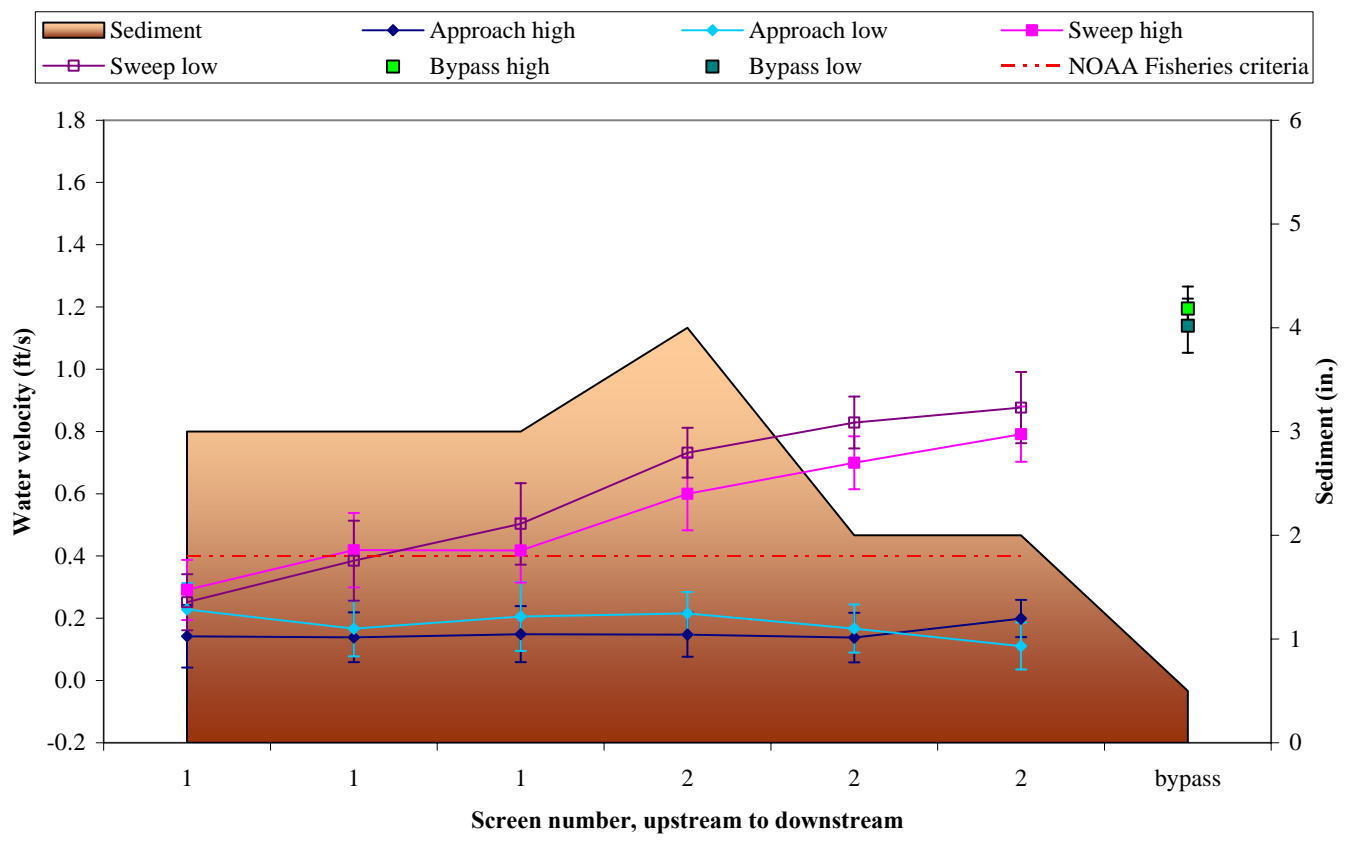

Figure 53. Water velocities and sediment depths at Fruitvale in May 2004. Error bars show turbulence ( \pm the root-mean-squared (RMS)) at each point.

Fruitvale - June 22, 2004

\begin{tabular}{|c|c|c|c|}
\hline$\square$ Sediment & $\longrightarrow$ Approach high & $\because$ Approach low & $\longrightarrow$ - Sweep high \\
\hline —-Sweep low & ㅁ Bypass high & ㅁ Bypass low & $-\cdots-$ NOAA Fisheries criteria \\
\hline
\end{tabular}

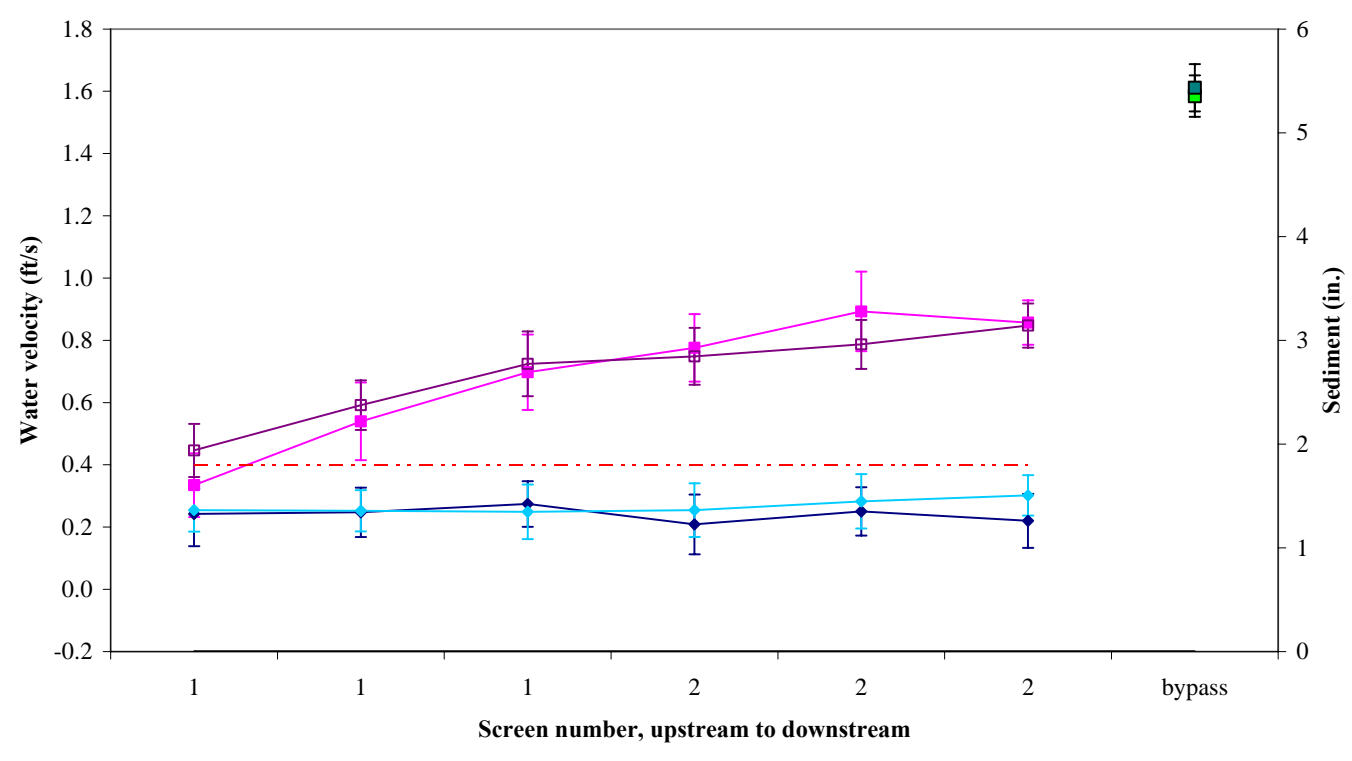

Figure 54. Water velocities and sediment depths at Fruitvale in June 2004. Error bars show turbulence ( \pm the root-mean-squared (RMS)) at each point. 


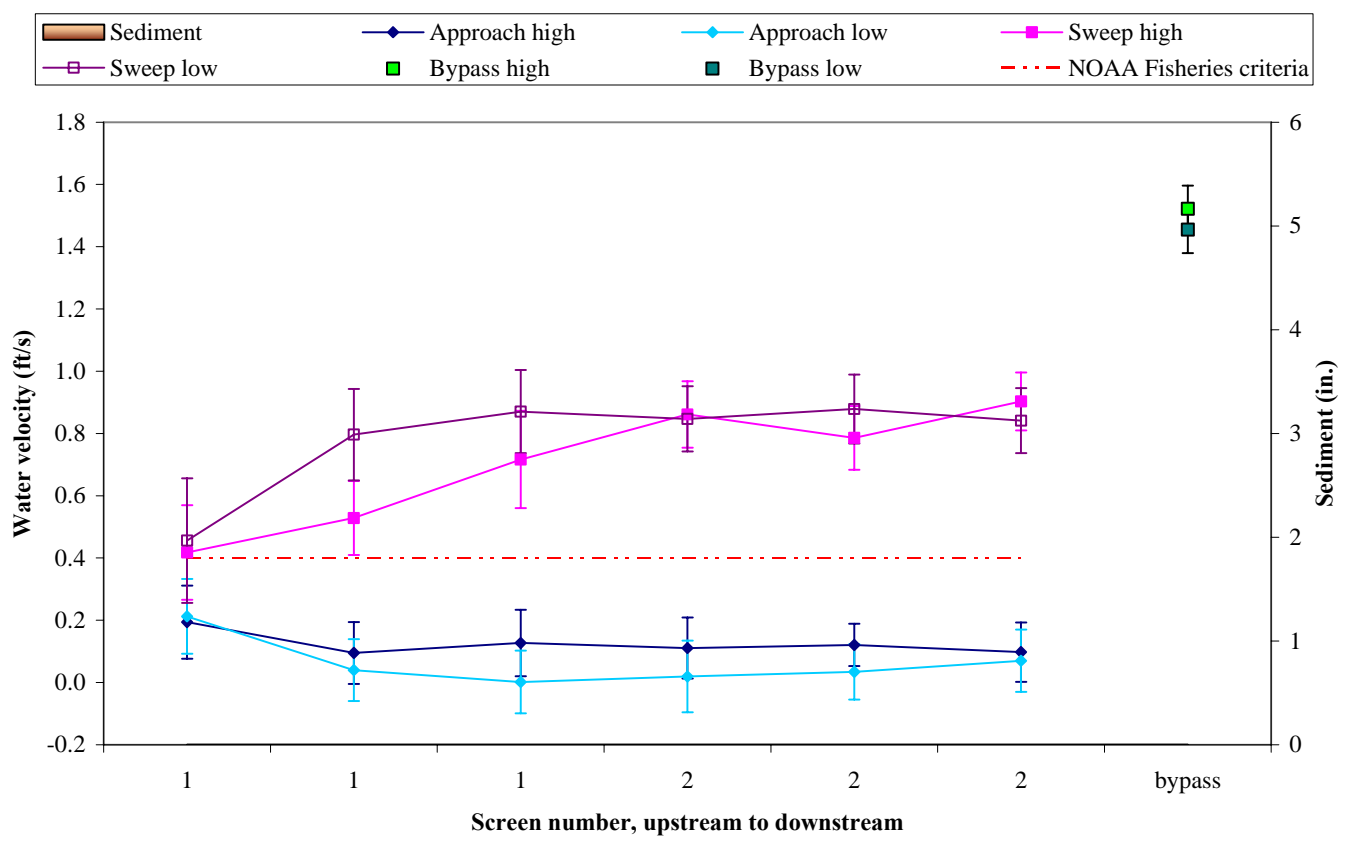

Figure 55. Water velocities and sediment depths at Fruitvale in September 2004. Error bars show turbulence ( \pm the root-mean-squared (RMS)) at each point.

\section{Naches-Selah}

The Naches-Selah site was visited on May 20, June 24, and September 24, 2004. In May, June, and September, 42, 92, and 28\% of approach velocities met NOAA Fisheries criteria, respectively (Figures 56 through 58). Sweep velocities were generally greater than approach velocities but did not increase towards the bypass. The average bypass velocity was greater than the average sweep velocity May and September. Ray Gilmour was notified of the high approach velocities on May 20 and he responded by changing the louver settings on May 25. We reevaluated the site on May 27 and found conditions to be somewhat improved, with $20 \%$ of the measured approach velocities greater than $0.4 \mathrm{ft} / \mathrm{s}$. This site has one of the worst records as far as meeting NOAA Fisheries velocity criteria (Table 4), and we recommend that site operating procedures and/or site structure be modified to protect migrating fish from injury as they pass through this site.

The screens are patched in places, but they appeared to be in good condition during all surveys. The caulking between the screens and under the screens was in good condition.

In June the fish gate just upstream of the bypass ramp was partially closed, causing very strange flow patterns in the bypass area. Water flowed freely over the weir and through the outfall during all surveys. The checkboard that had been placed just below the outfall pipe in the cement apron last year was present in May, forming a short turbulent plunge pool just below the outfall pipe. Water then flowed over the checkboard but was only a few inches deep across the cement apron until it got to the bypass stream. This board was removed before the June survey, and in June and September the water depth at the point of discharge was less than $1 \mathrm{ft}$. 
Naches-Selah - May 20, 2004

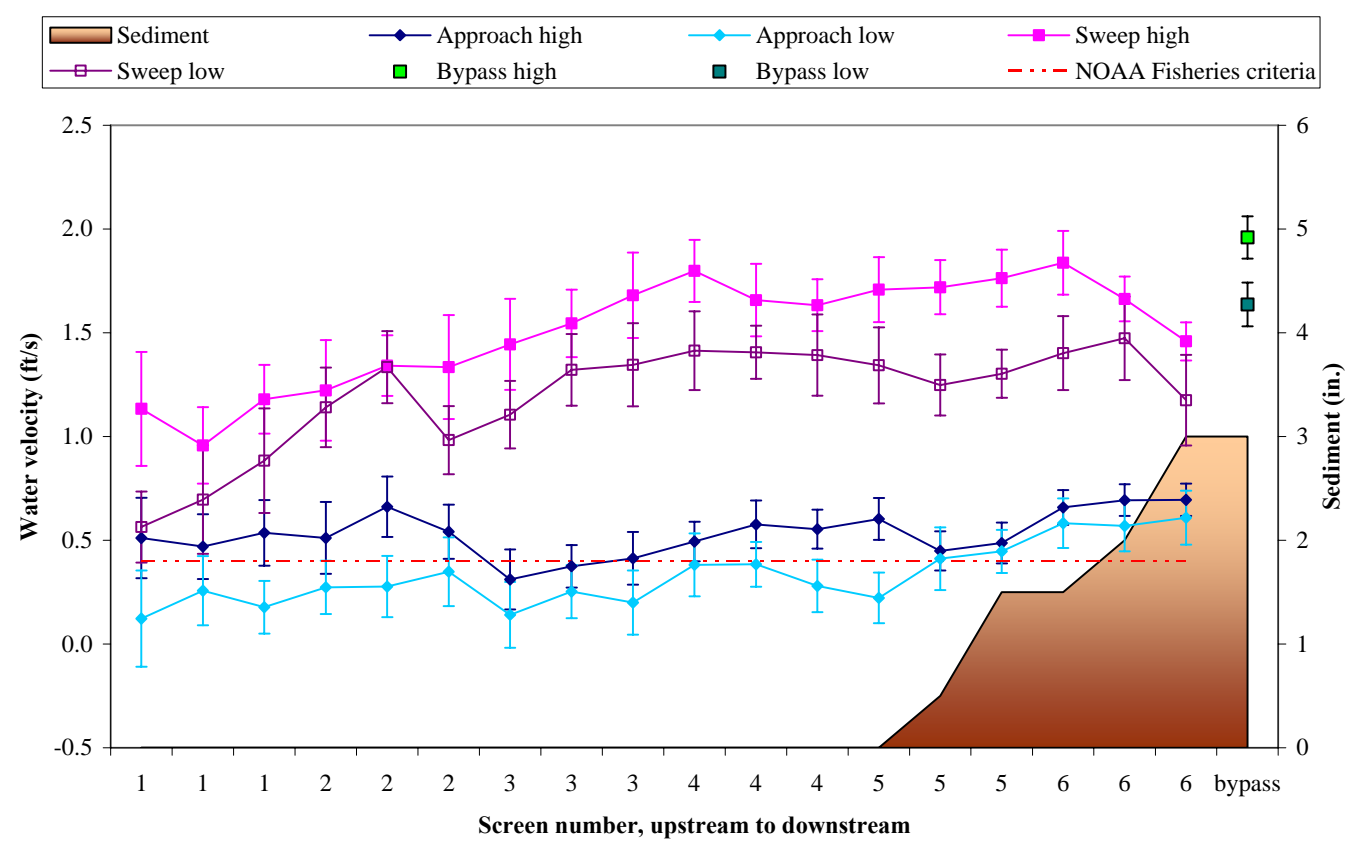

Figure 56. Water velocities and sediment depths at Naches-Selah in May 2004. Error bars show turbulence ( \pm the root-mean-squared (RMS)) at each point.

Naches-Selah - June 24, 2004

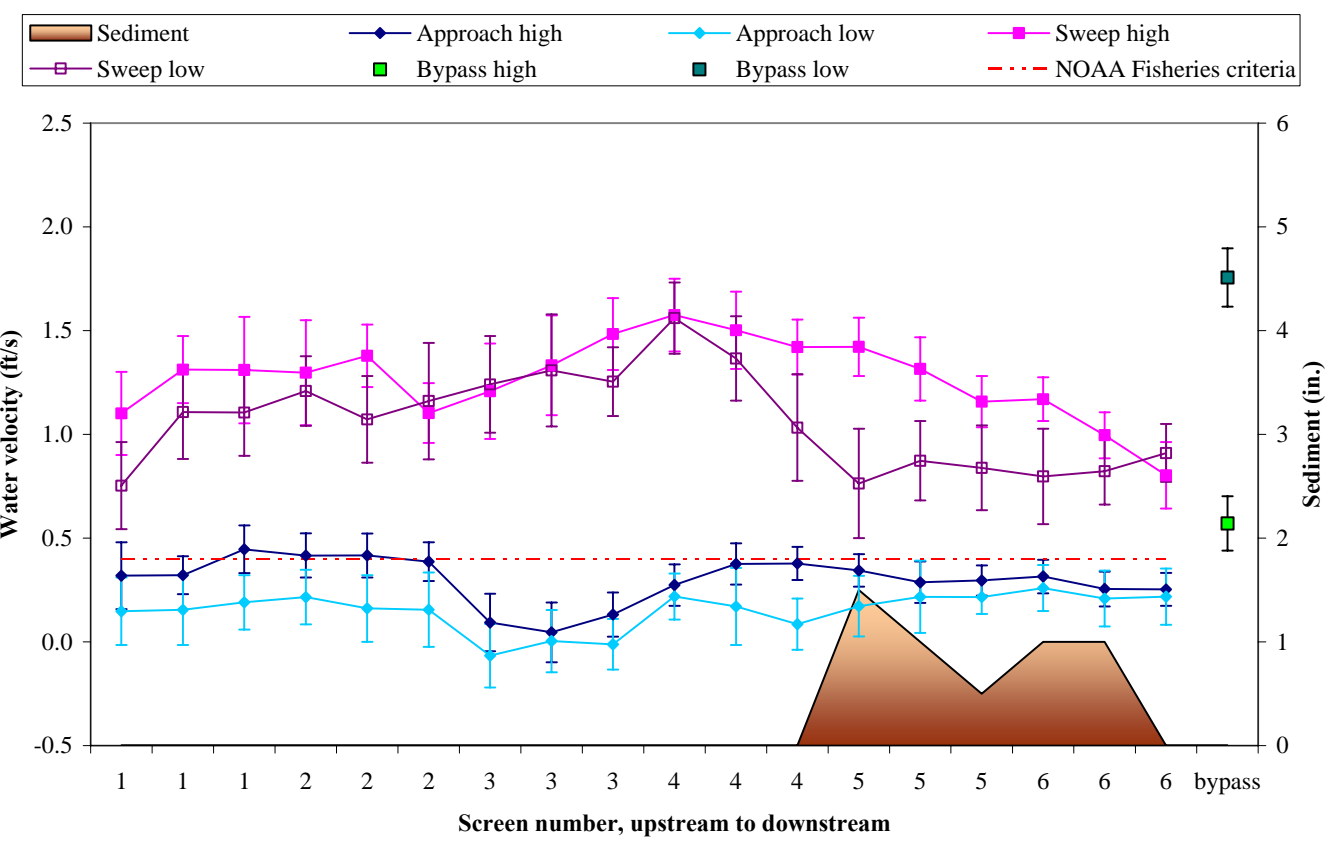

Figure 57. Water velocities and sediment depths at Naches-Selah in June 2004. Error bars show turbulence ( \pm the root-mean-squared (RMS)) at each point. 


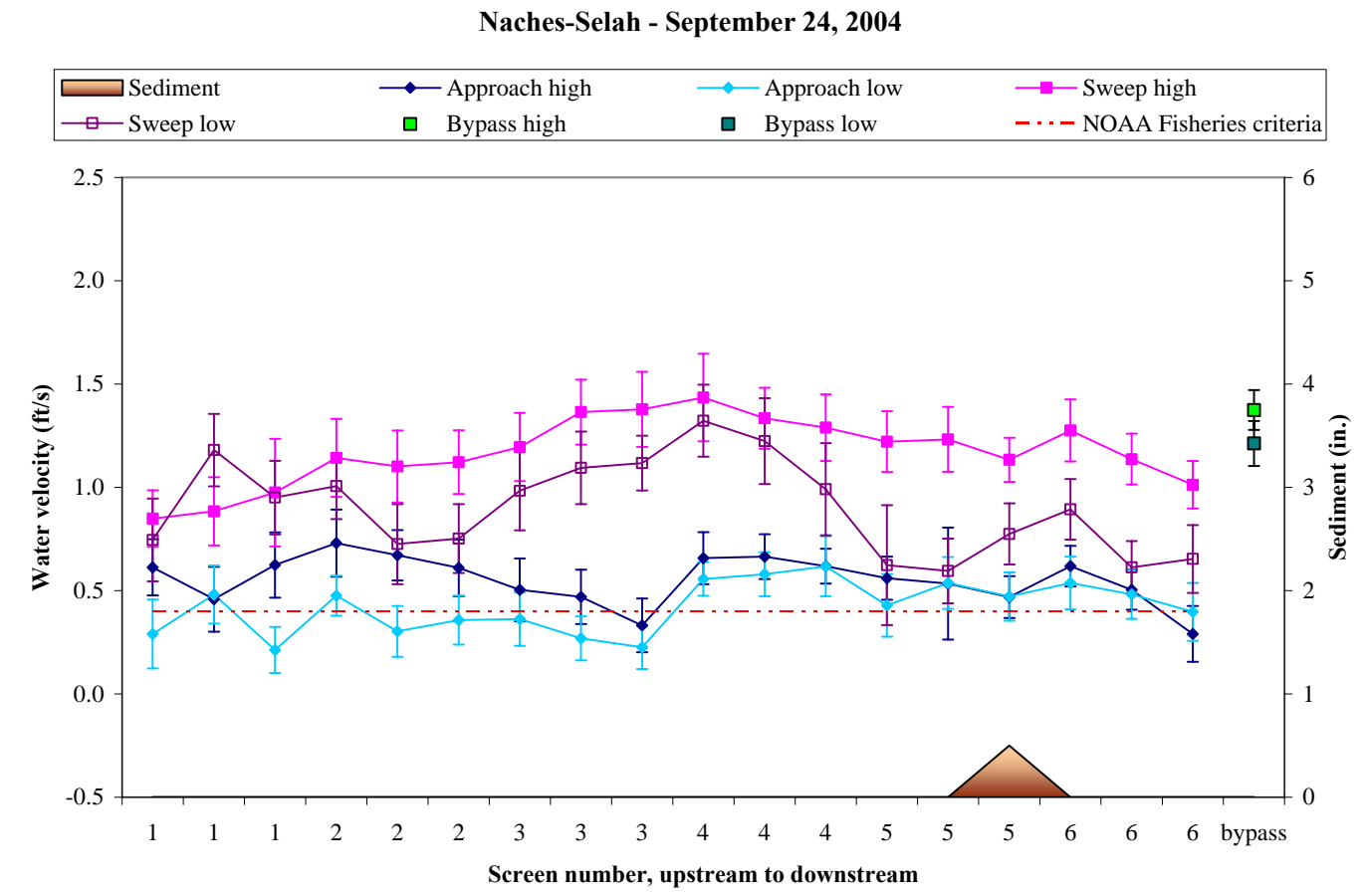

Figure 58. Water velocity and sediment depths at Naches-Selah in September 2004. Error bars show turbulence ( \pm the root-mean-squared (RMS)) at each point.

\section{Packwood}

The Packwood site was added to our route in 2004. It is a flat-plate screen with two screen panels and a short bypass with no ramp. The bypass is an open-channel design with several plunge-pools created by checkboards to get back to stream level at the outfall (Figure 59). The site was visited May 24, June 28, and September 27, 2004, though the site was shut down before the September evaluation. Approach velocities met NOAA Fisheries criteria 100\% of the time during all surveys (Figures 60 through 62). Sweep velocities were generally greater than approach velocities. The design of the site does not allow for measurement of bypass velocities with PNNL equipment, and it was not measured during our evaluations.

Sometime before the September evaluation, a beaver had taken up residence near the headgate. Debris from the beaver dam was removed September 13 and 15 to allow water into the site. In May it was noted that the mechanical brushes do not function well to remove algae and debris from the screens. The minimal stroke distance combined with slow movement makes them somewhat ineffective at pushing leaves and sticks out away from the screens. Since this site has nominal water movement and therefore little debris carrying capacity, it may be necessary to pay special attention to ensuring that it is kept clean.

The screen and seal materials appeared to be in good condition during all surveys, although the gap between the downstream end of screen 2 and the concrete wall of the site was not filled. The bypass conditions were generally good. Water flowed over the bypass weir and through the system of plunge-pools. In May it was noted that there was an accumulation of sticks at the outlet of the bypass channel that could have caused problems for larger fish. 


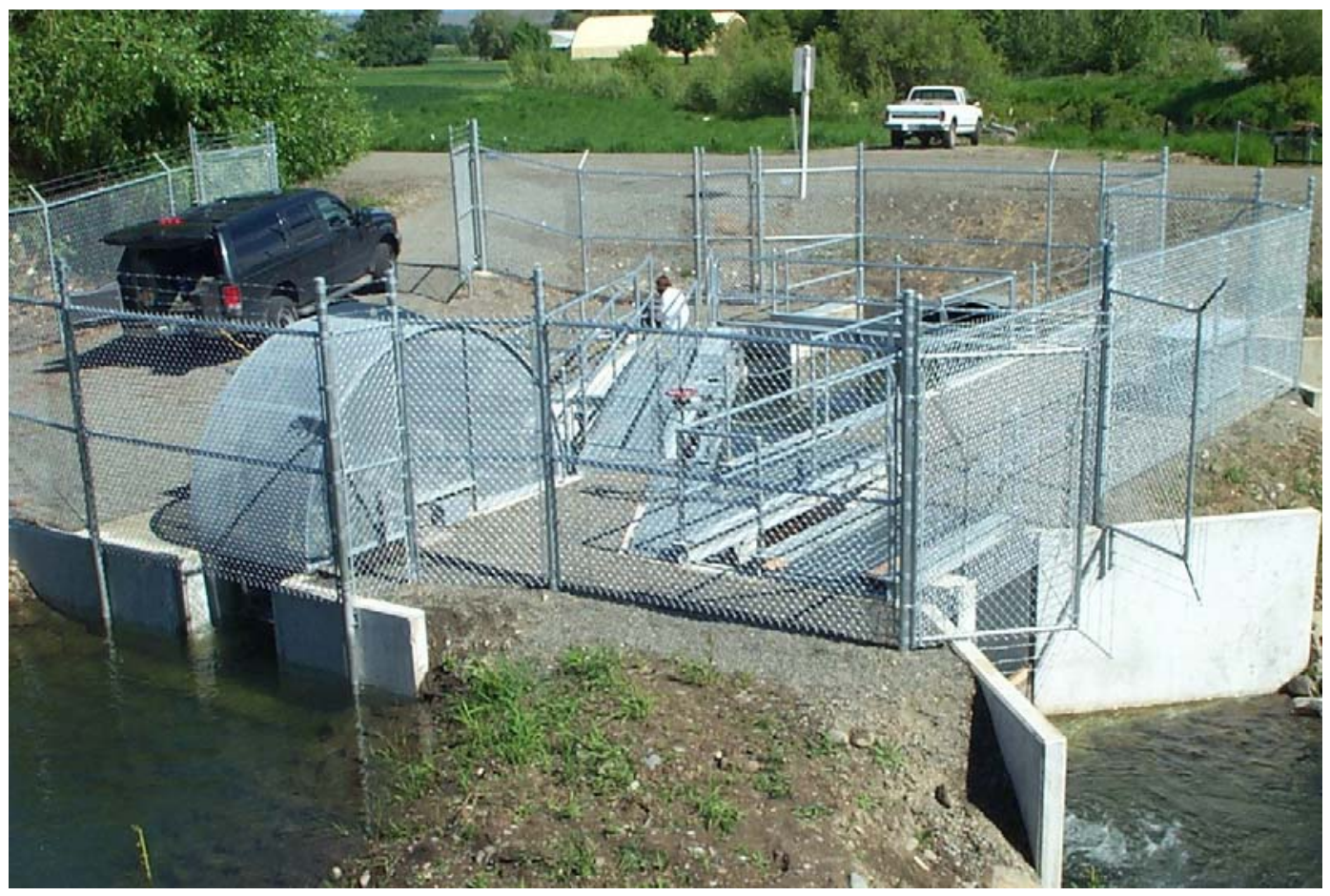

Figure 59. View of the Packwood site. (The canal is on the left; bypass channel is on the right.)

Packwood - May 24, 2004

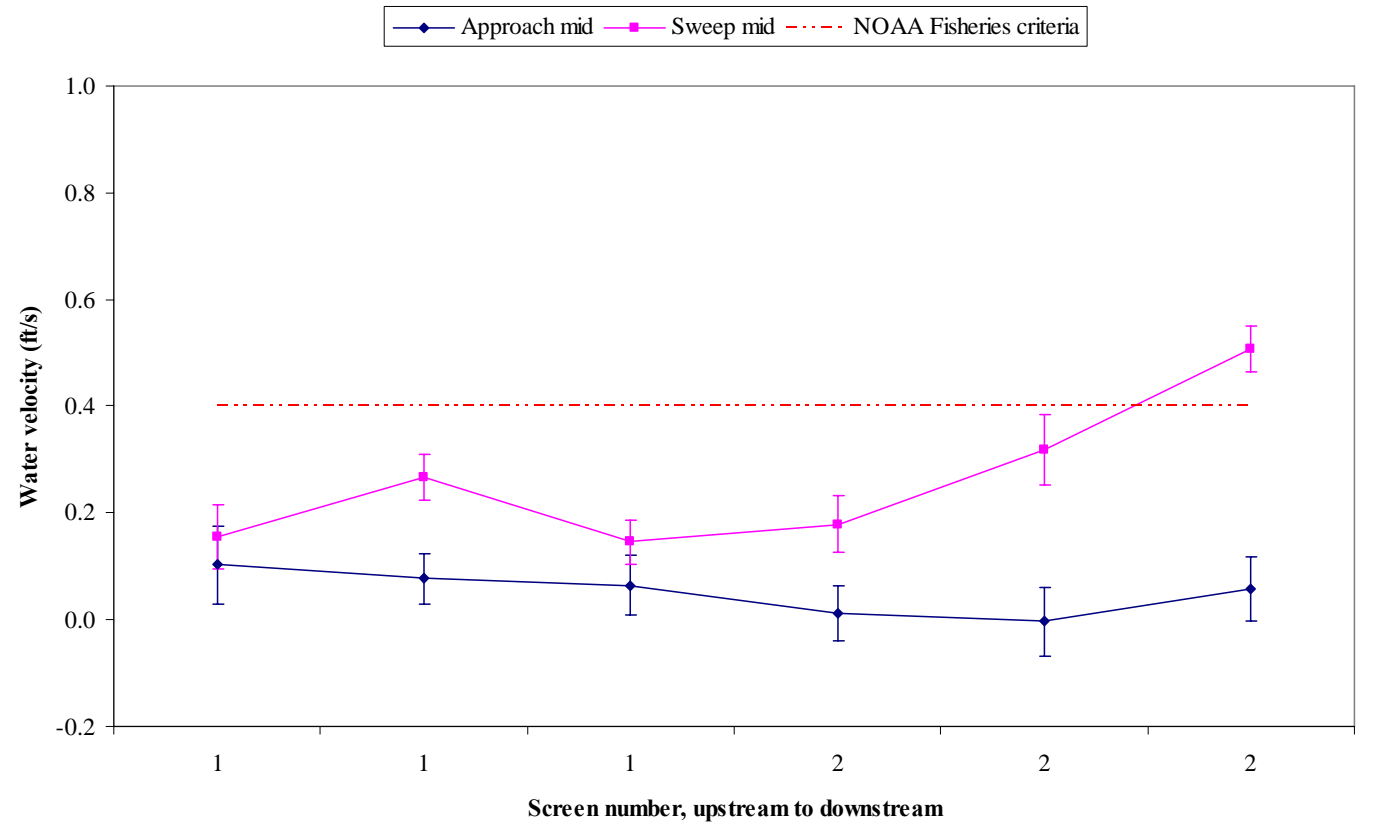

Figure 60. Water velocities and sediment depths at Packwood in May 2004. Error bars show turbulence ( \pm the root-mean-squared (RMS)) at each point. 
Packwood - June 28, 2004

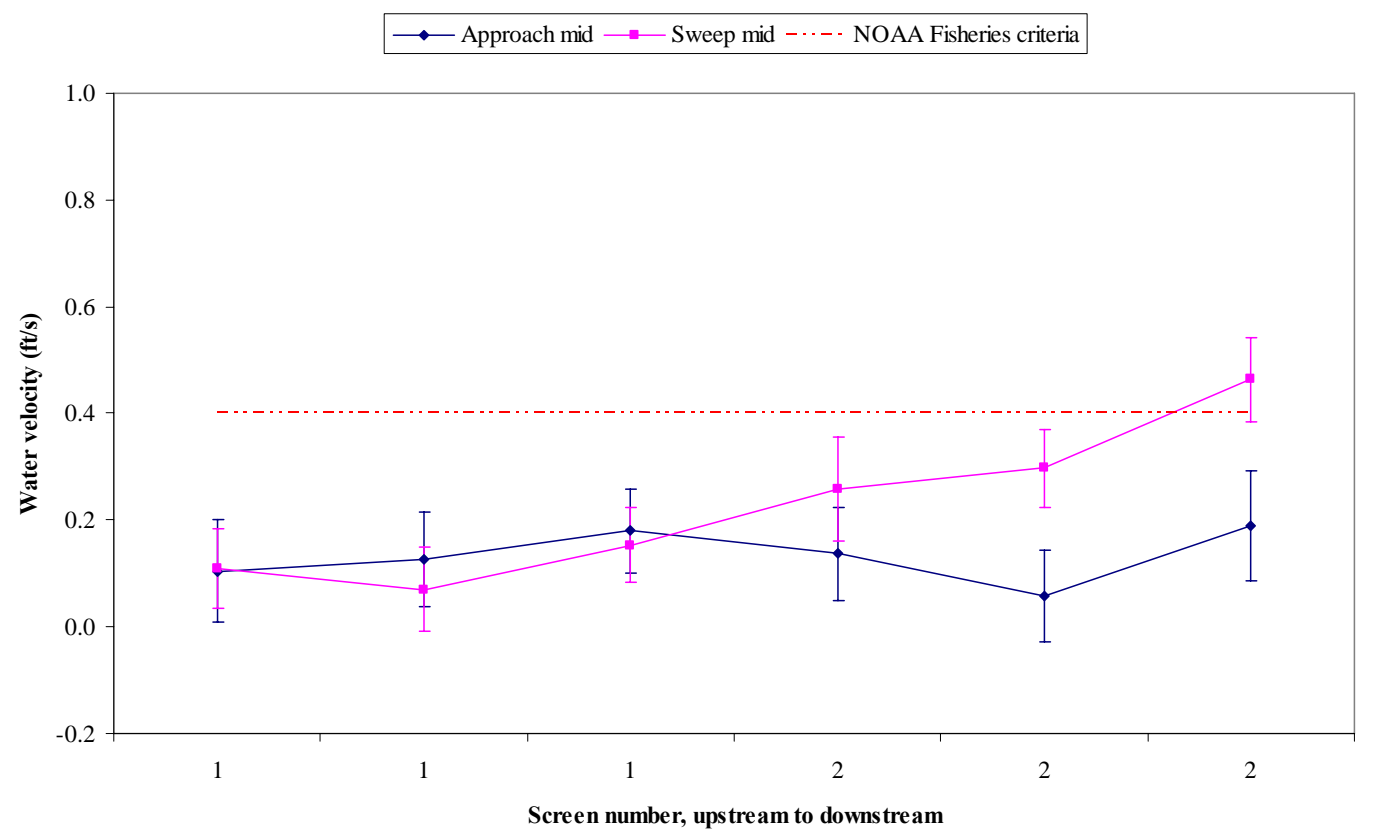

Figure 61. Water velocities and sediment depths at Packwood in June 2004. Error bars show turbulence ( \pm the root-mean-squared (RMS)) at each point.

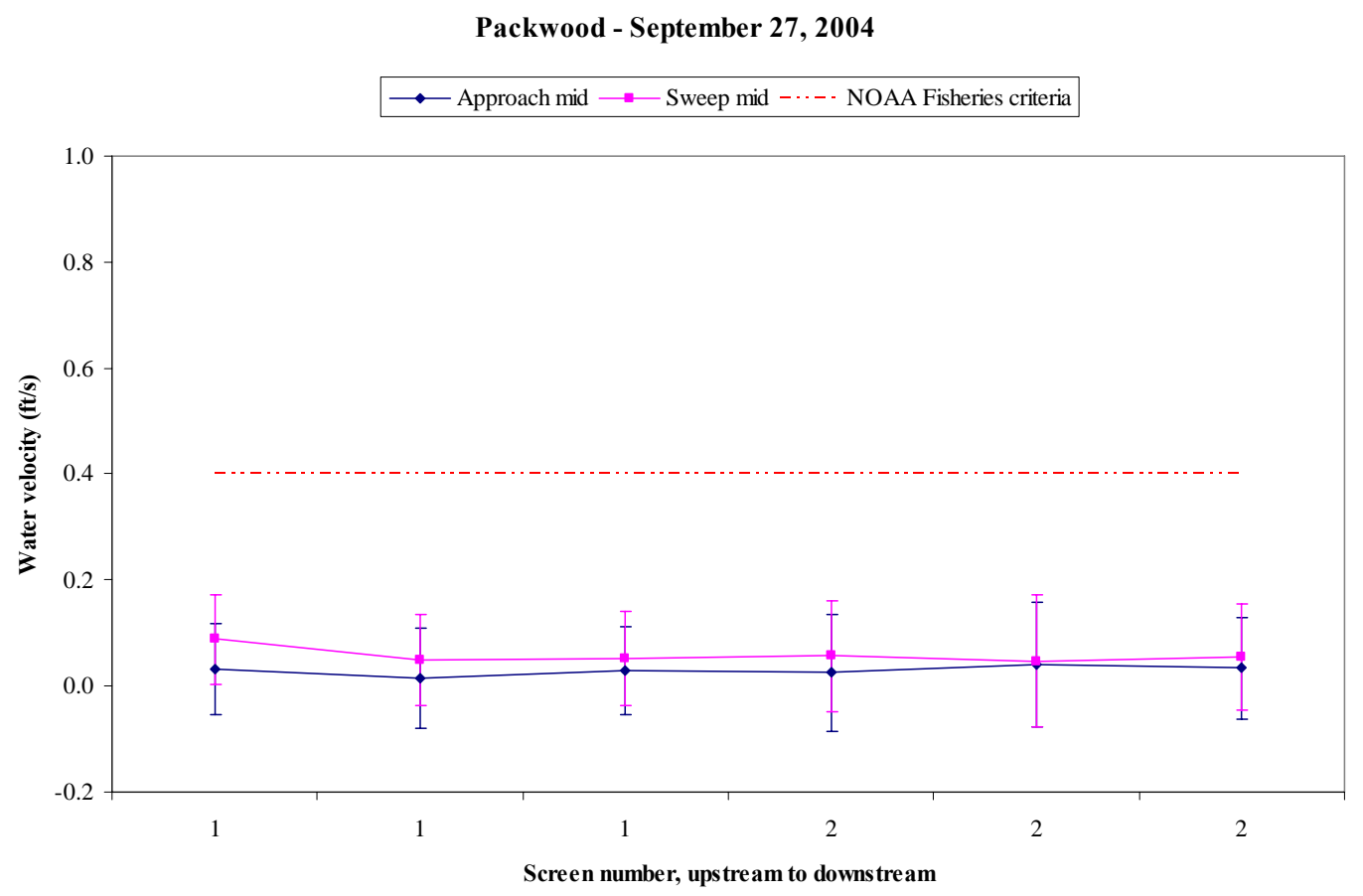

Figure 62. Water velocities and sediment depths at Packwood in September 2004. Error bars show turbulence ( \pm the root-mean-squared (RMS)) at each point. 


\section{Selah-Moxee}

Selah-Moxee is a site that was added in 2004. It is a flat-plate site with 12 relatively short screens and a typical bypass setup (Figure 63). Due to the length of the screens, only two velocity measurements were taken per screen. The site was evaluated on May 19, June 29, and September 22, 2004. In May and September $100 \%$ of the measured approach velocities met the NOAA Fisheries criteria of less than or equal to $0.4 \mathrm{ft} / \mathrm{s}$, though only $83 \%$ of measured approach velocities met the criteria in June (Figures 64 through 66). Ray Gilmour was notified concerning the elevated approach velocities on July 1 . We received notification on July 7 that the louvers had been adjusted. We reevaluated the site on July 14 and found the velocity conditions to be improved. Sweep velocities were always greater than approach velocities, and the average bypass velocity was greater than the average sweep during all surveys. The sweep velocity increased towards the bypass in June.

Underwater video surveys showed that the screens and seals were generally in good condition. Debris buildup in the forebay was reasonable during all months, though in June there was some growth of aquatic plants in the forebay. The automatic cleaning brushes generally worked well, though the most upstream screen was covered with algae during all three surveys.

Bypass conditions were safe for fish passage during all surveys. Water ran freely over the weir and out the outfall, where the water depth was always greater than $1 \mathrm{ft}$.

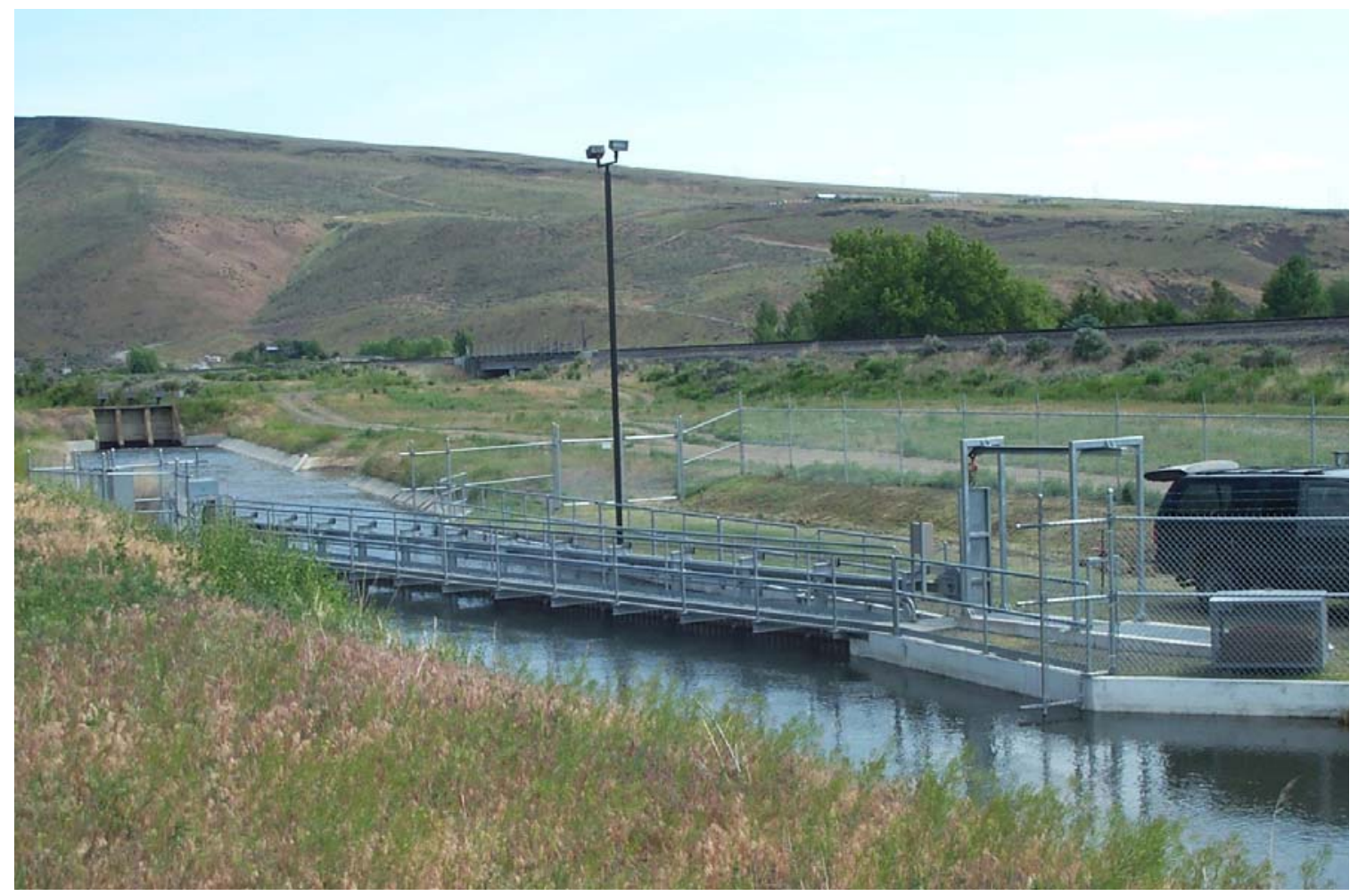

Figure 63. View of Selah-Moxee from the canal side. The bypass tube passes through the dike from which the picture was taken and exits at the river behind the photographer. 
Selah-Moxee - May 18, 2004

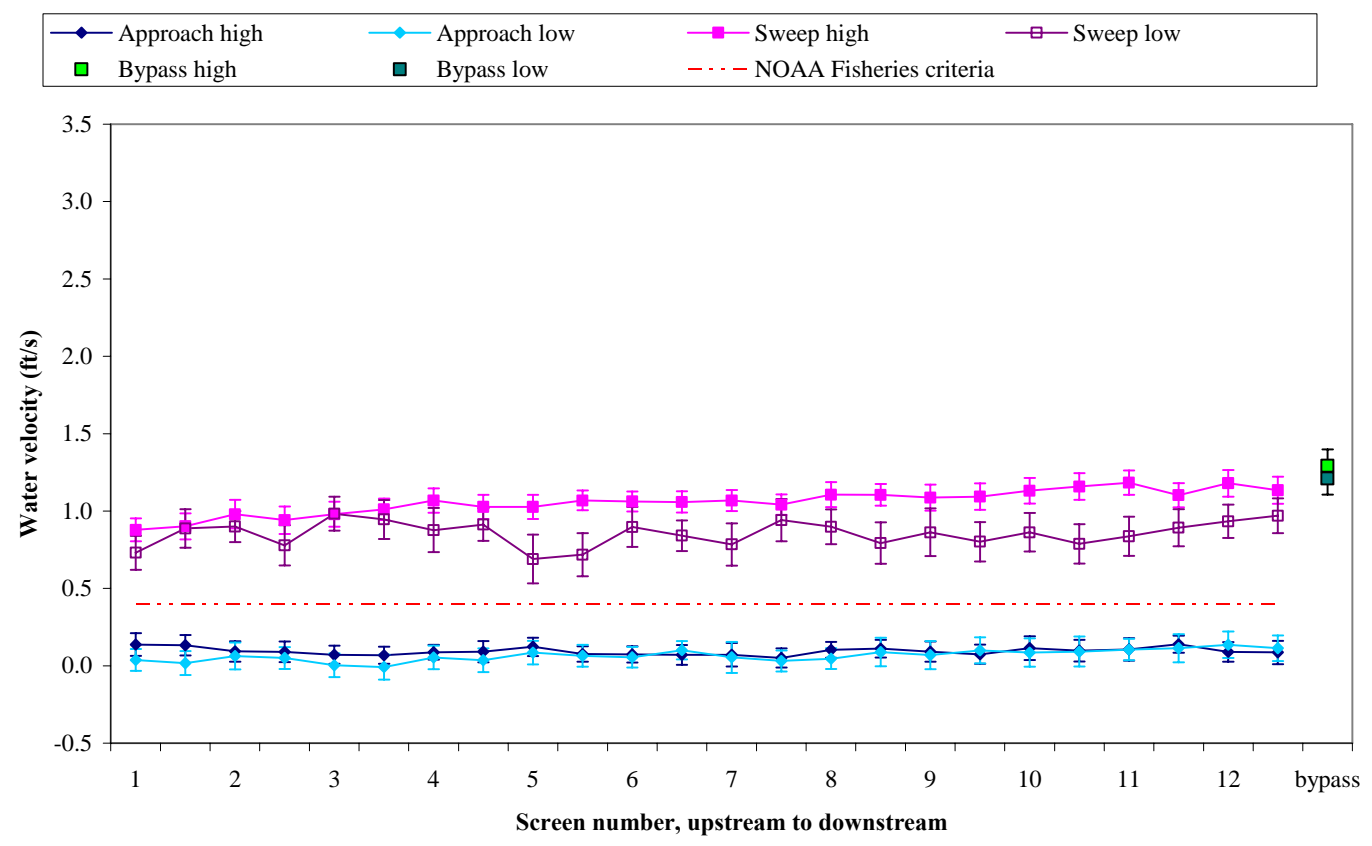

Figure 64. Water velocities and sediment depths at Selah-Moxee in May 2004. Error bars show turbulence ( \pm the root-mean-squared (RMS)) at each point.

Selah-Moxee - June 29, 2004

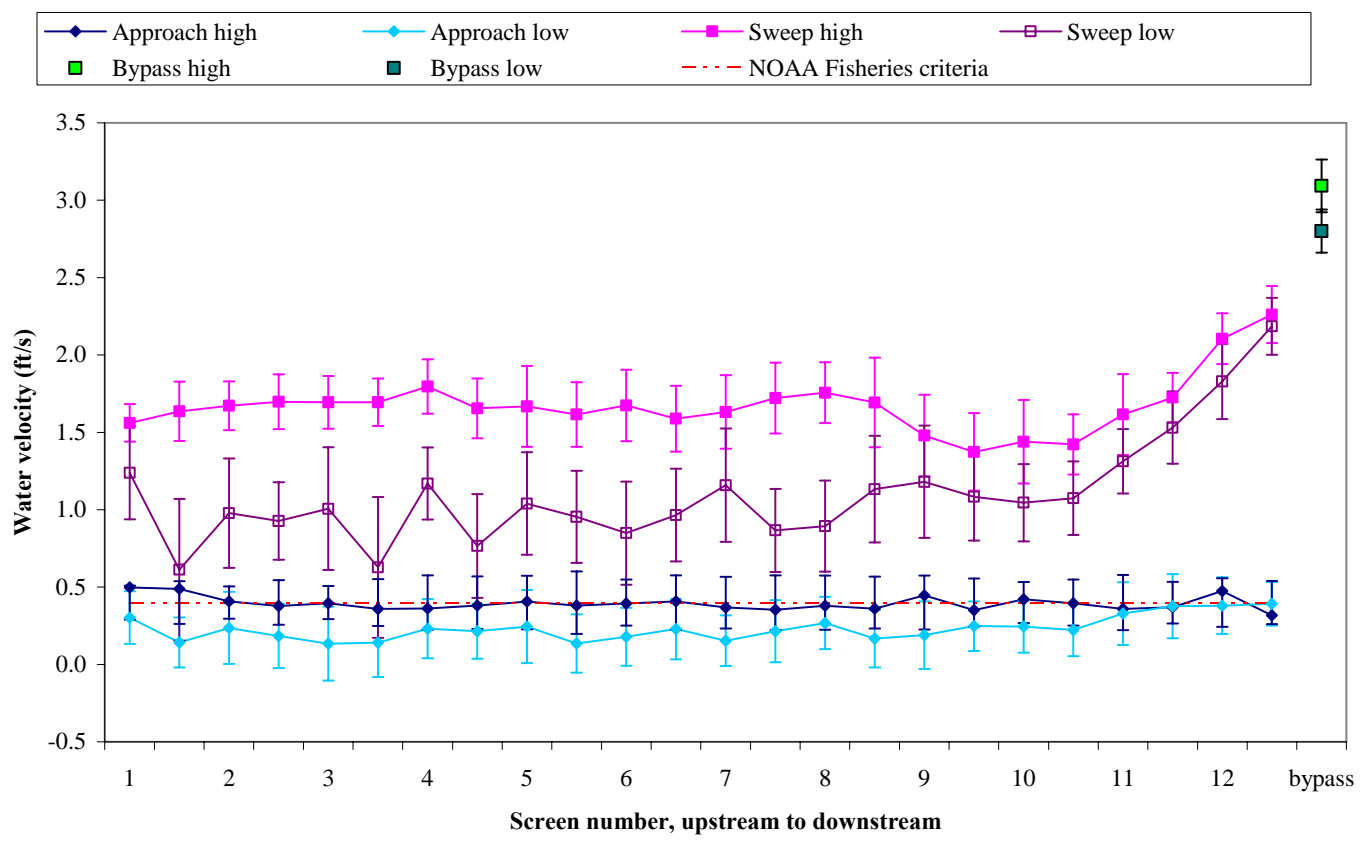

Figure 65. Water velocities and sediment depths at Selah-Moxee in June 2004. Error bars show turbulence ( \pm the root-mean-squared (RMS)) at each point. 


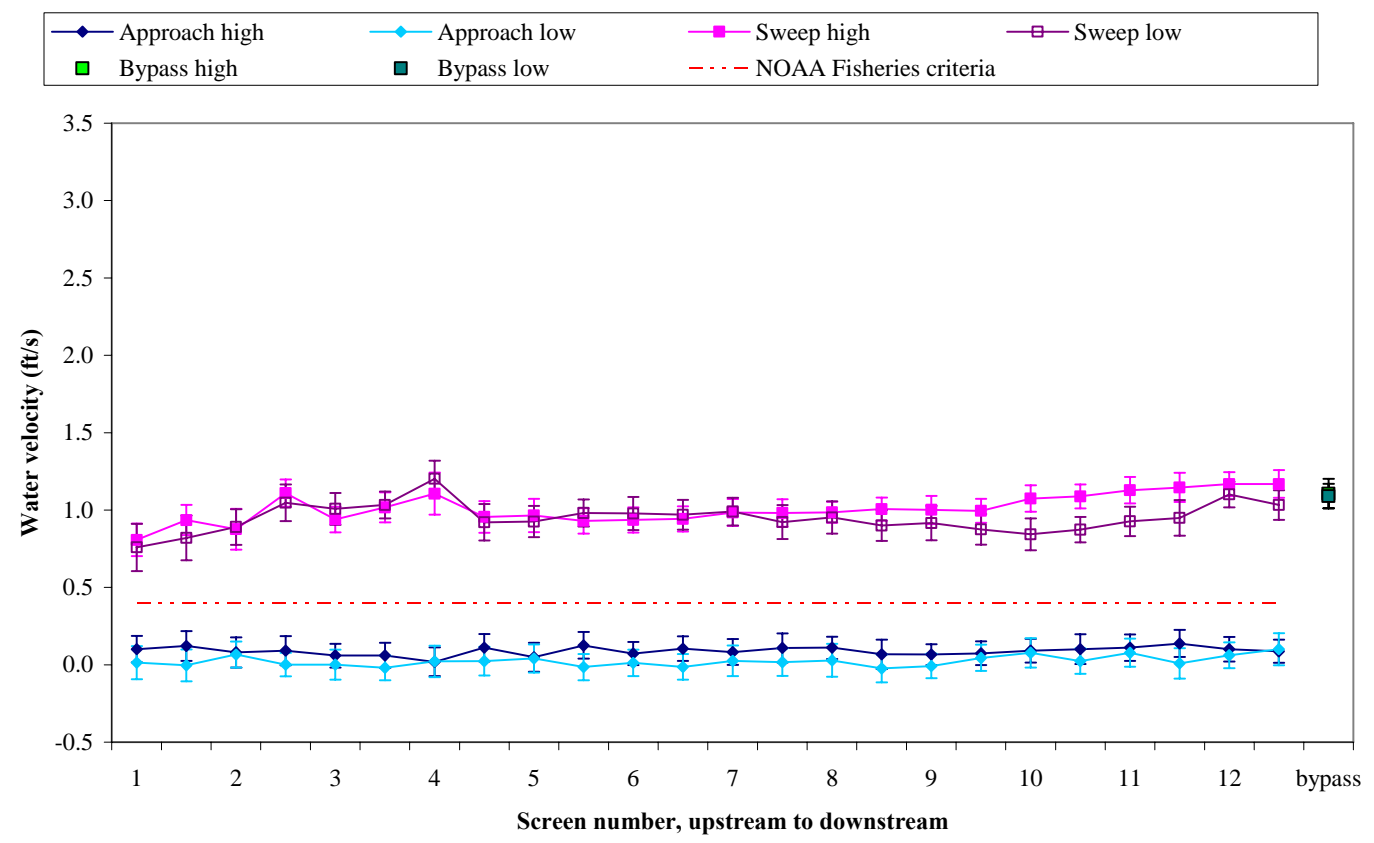

Figure 66. Water velocities and sediment depths at Selah-Moxee in September 2004. Error bars show turbulence ( \pm the root-mean-squared (RMS)) at each point.

\section{Union Gap}

The Union Gap site was evaluated on May 19, July 1, and September 22, 2004. In May, July, and September, 21, 100, and 50\% of approach velocities met NOAA Fisheries criteria, respectively (Figures 67 through 69). Sweep velocities were always higher than approach velocities, but did not increase toward the bypass. The average bypass velocity was slower than the average sweep velocity. Ray Gilmore was notified on May 19 that greater than $10 \%$ of the approach velocity measurements exceeded $0.4 \mathrm{ft} / \mathrm{s}$. We did not receive a response from him concerning this site. We followed up during our regularly scheduled evaluation in July, and found the velocity conditions to be much improved.

The screen material was in good condition during all surveys. The gaps between the screens were sealed before the 2004 season and these seals were generally in good condition. No algae or aquatic plant growth was observed in the forebay during 2004.

Bypass conditions were safe for fish passage during all surveys. Water ran freely behind the weir and through the outfall pipe, and the water depth at the point of discharge was always greater than $1 \mathrm{ft}$. 
Union Gap - May 19, 2004

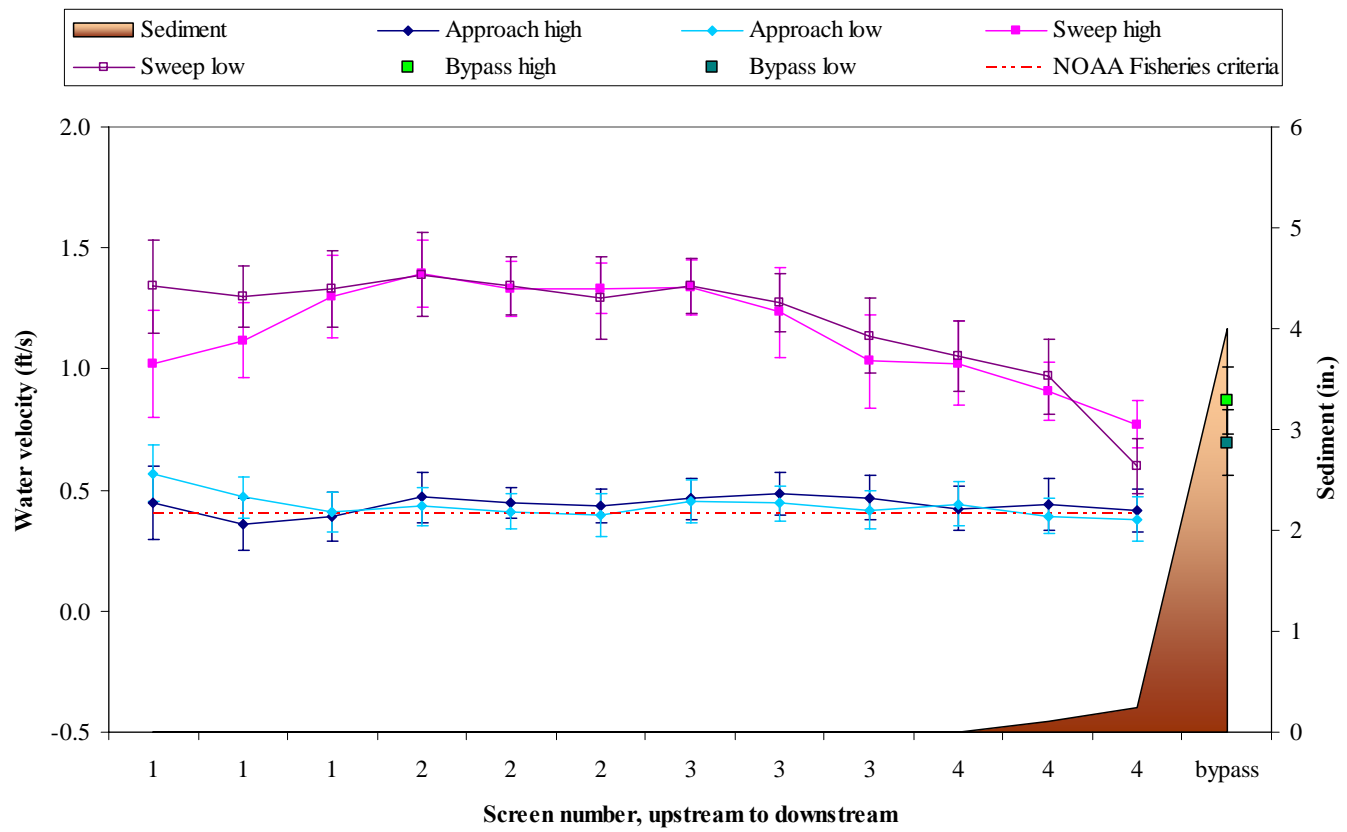

Figure 67. Water velocities and sediment depths at Union Gap in May 2004. Error bars show turbulence ( \pm the root-mean-squared (RMS)) at each point.

Union Gap - July 1, 2004

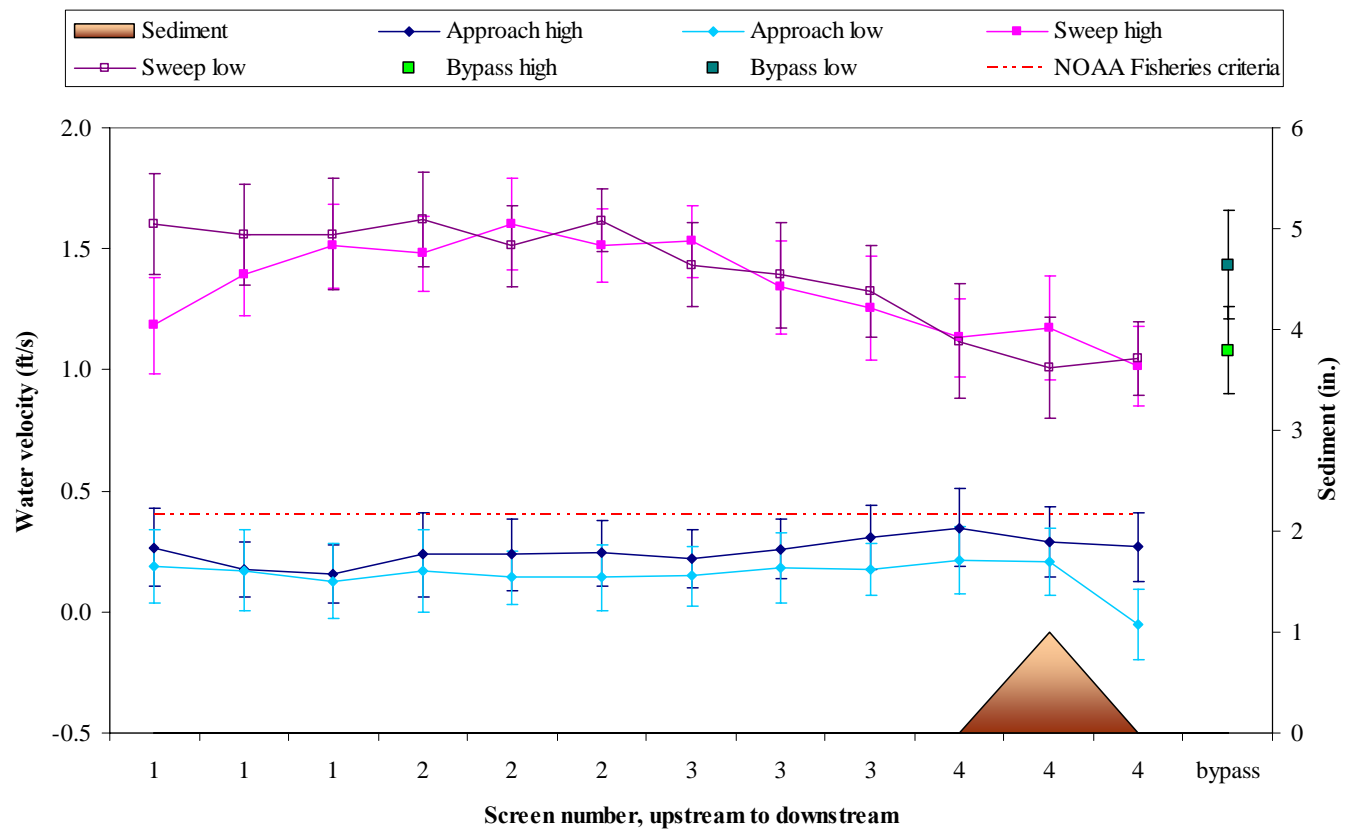

Figure 68. Water velocities and sediment depths at Union Gap in July 2004. Error bars show turbulence ( \pm the root-mean-squared (RMS)) at each point. 


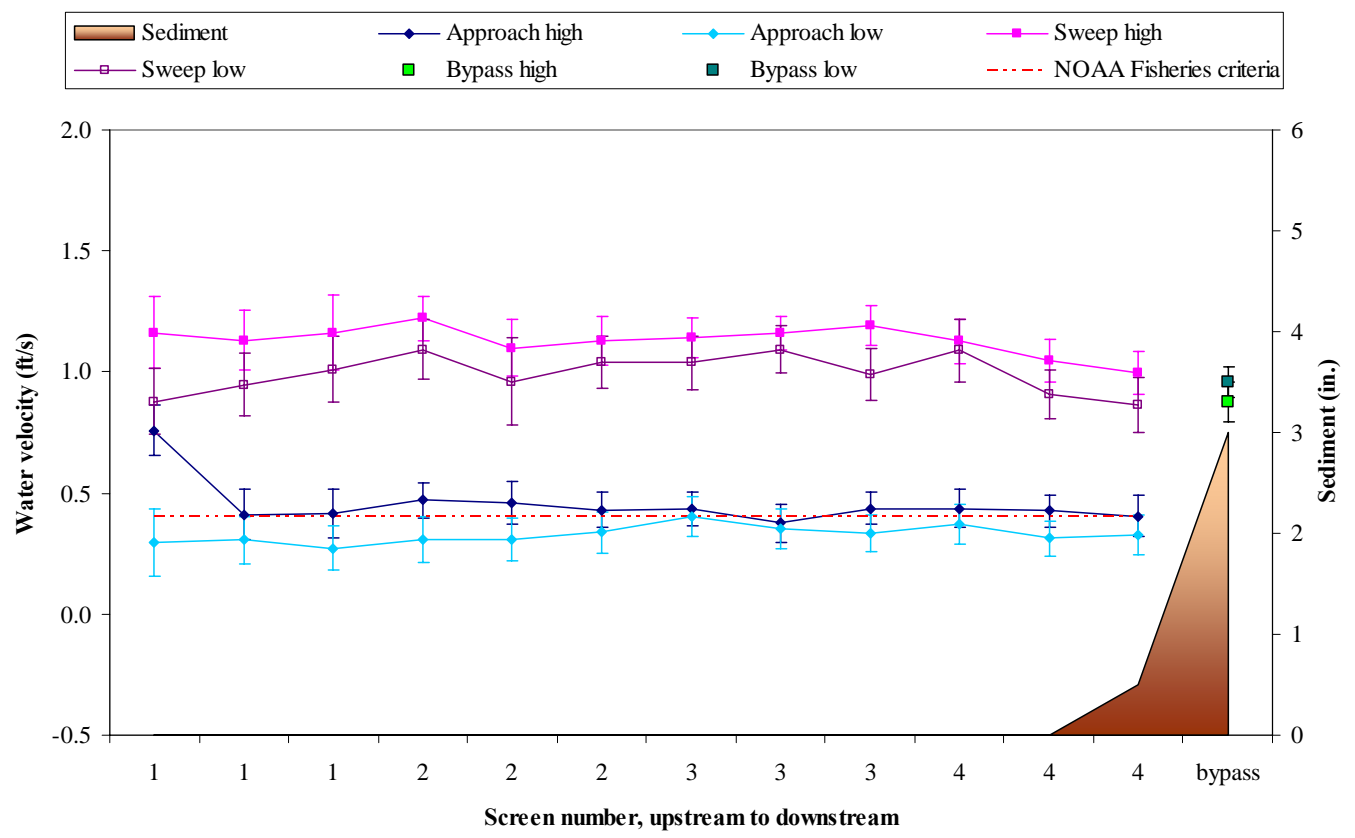

Figure 69. Water velocities and sediment depths at Union Gap in September 2004. Error bars show turbulence ( \pm the root-mean-squared (RMS)) at each point.

\section{Yakima-Tieton}

The Yakima-Tieton site was evaluated on May 20, June 24, and September 24, 2004. In May, June, and September, 100, 46, and 100\% of approach velocities met NOAA Fisheries criteria, respectively (Figures 70 through 72). Sweep velocities were always higher than approach velocities. Sweep velocities did not increase towards the bypass, and the average bypass velocity was less than the average sweep velocity in June and September.

The screens appeared to be in good condition during all surveys. Several of the screen seals have missing or failing caulking and have been in a similar condition for the past several years, and in May we observed two holes on the upstream edge of the seal between screens 3 and 4 that were large enough to allow small fish to pass. We recommend that the screen seals be repaired and re-caulked.

Bypass and outfall conditions met NOAA Fisheries criteria except in May when there was only 7 inches of water across the apron at the outfall. Water flowed freely over the weir and out the outfall. 
Yakima-Tieton - May 20, 2004

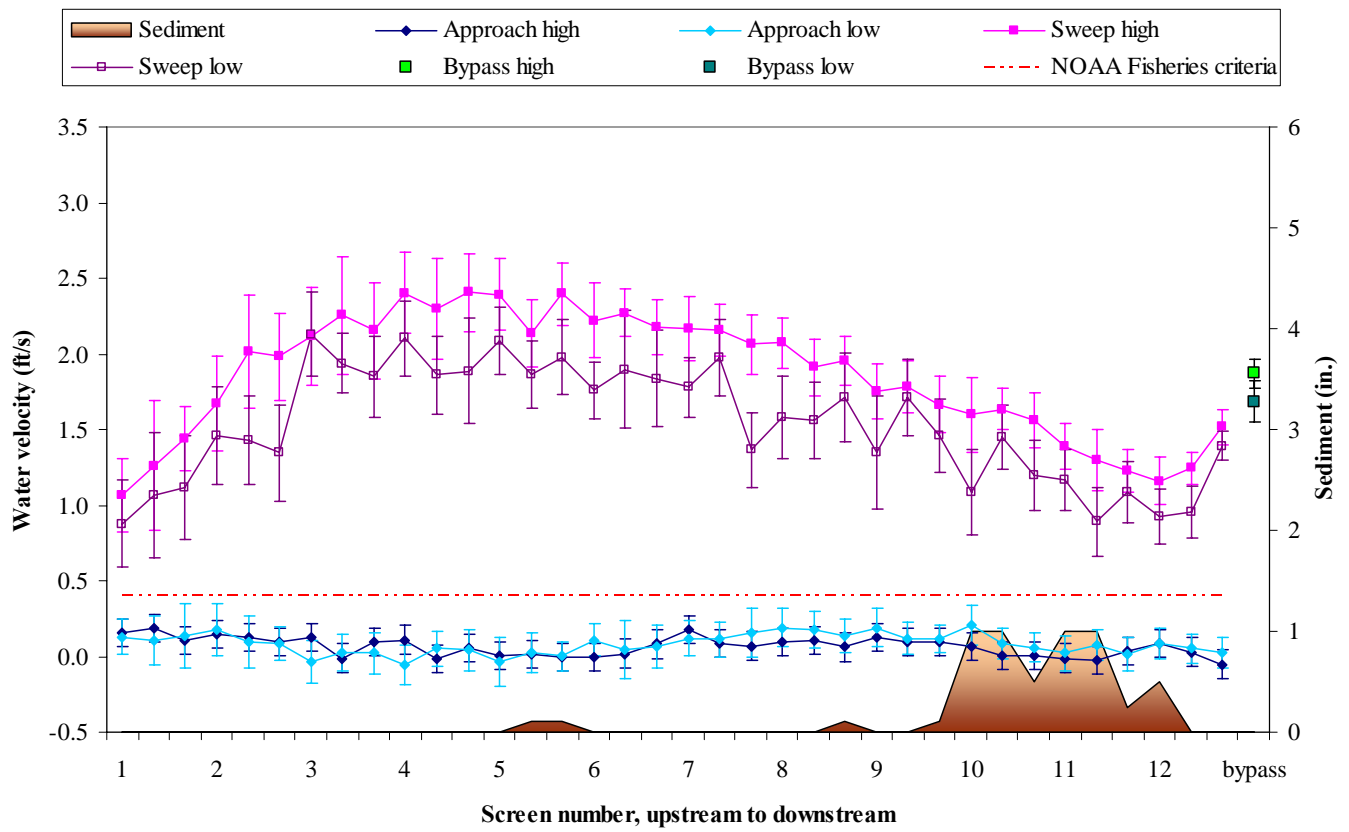

Figure 70. Water velocities and sediment depths at Yakima-Tieton in May 2004. Error bars show turbulence ( \pm the root-mean-squared (RMS)) at each point.

\section{Yakima-Tieton - June 24, 2004}

\begin{tabular}{|c|c|c|c|}
\hline$\square$ Sediment & —- Approach high & $\because$ Approach low & - Sweep high \\
\hline
\end{tabular}

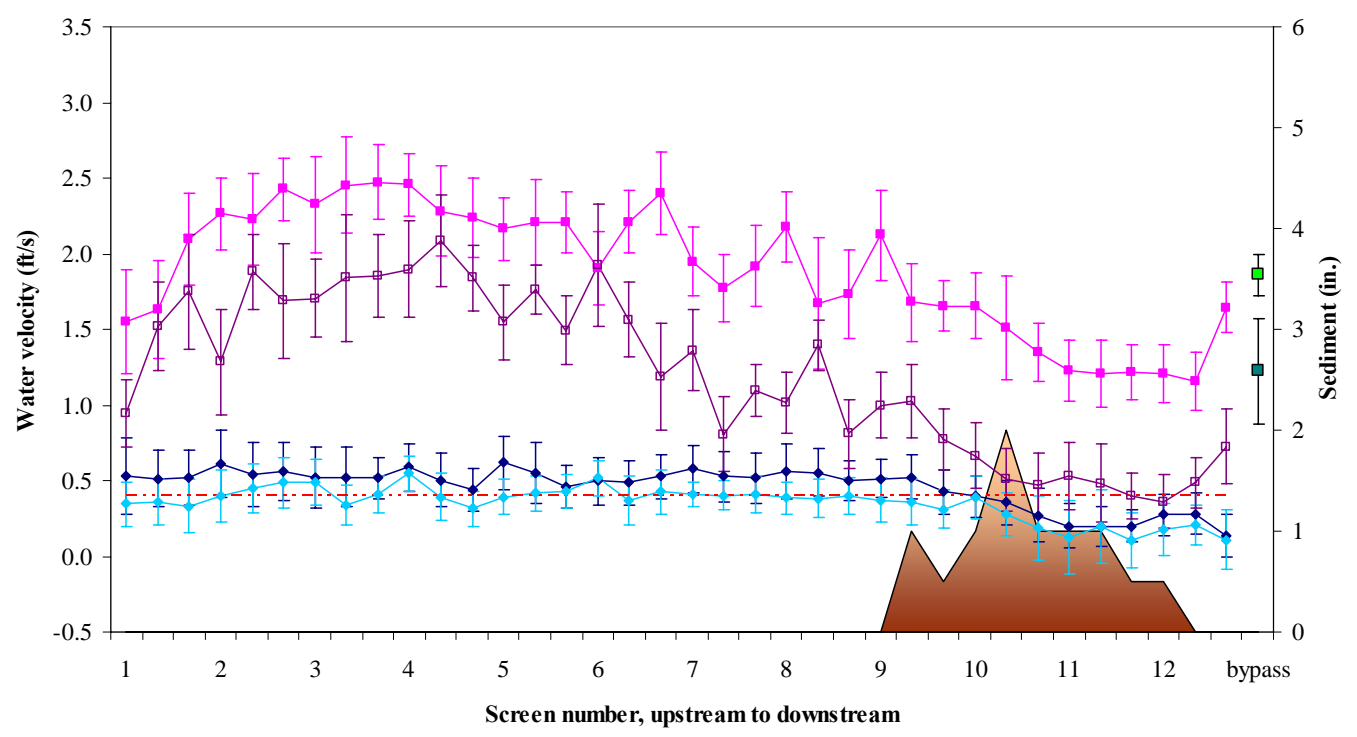

Figure 71. Water velocities and sediment depths at Yakima-Tieton in June 2004. Error bars show turbulence ( \pm the root-mean-squared (RMS)) at each point. 


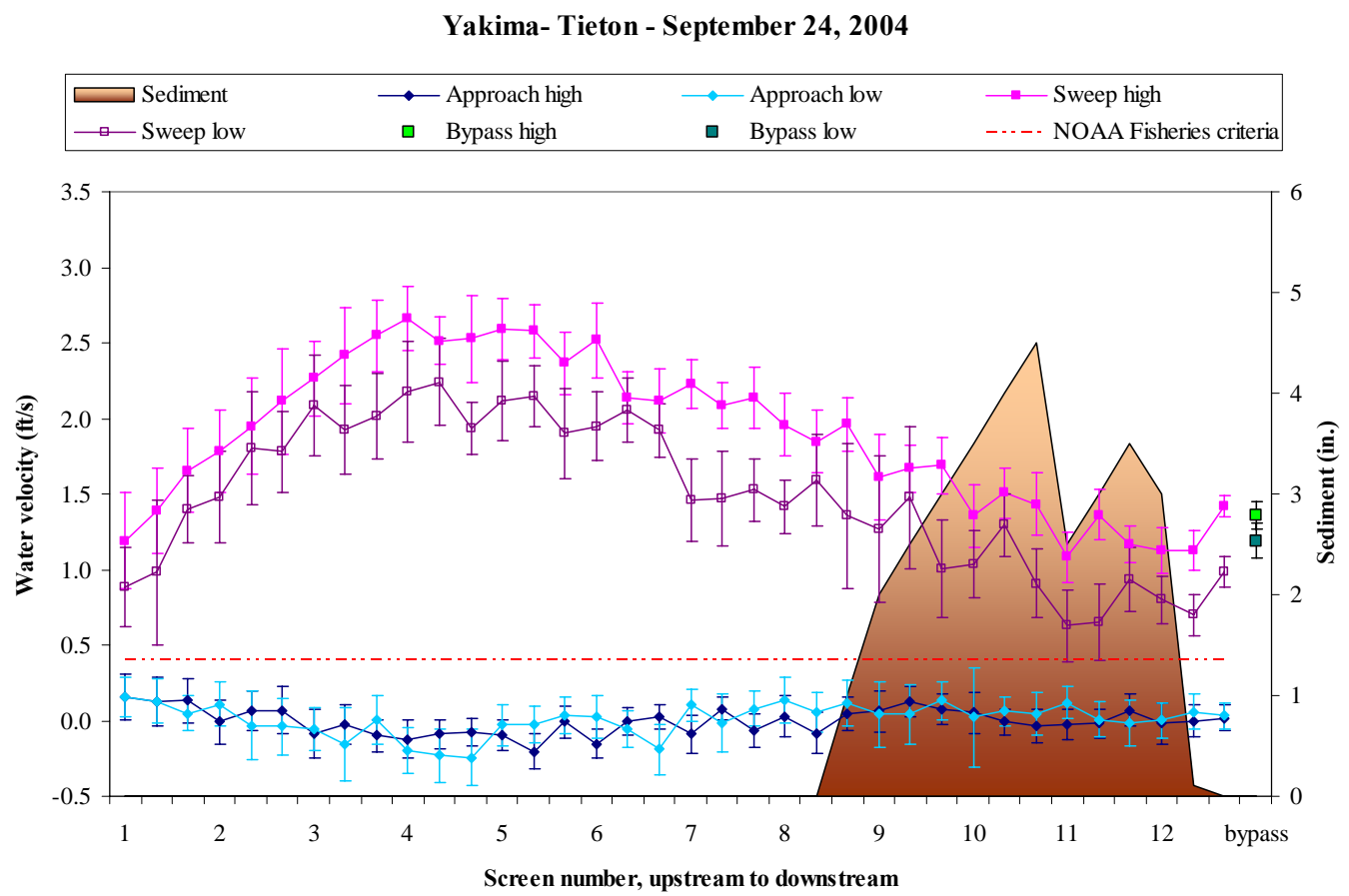

Figure 72. Water velocities and sediment depths at Yakima-Tieton in September 2004. Error bars show turbulence ( \pm the root-mean-squared (RMS)) at each point.

\section{Younger}

The Younger site was visited on May 24, June 28, and September 27, 2004. In May, 83\% of approach velocities met NOAA Fisheries criteria, while in June and September, 100\% of approach velocities met NOAA Fisheries criteria during all surveys (Figures 73 through 75). Ray Gilmour was notified on May 26 about the high approach velocity, though there was not much he could do about it, and the conditions were improved in June. Sweep velocities were generally higher than approach velocities, though they did not increase towards the downstream end of the site.

The screens and seals were in good condition during all surveys. In June and September it appeared as though the site was receiving significant amount of debris, though it was being cleaned every 1 to 3 days. The brushes seemed to be mostly effective, although they were turned off before the September evaluation. There was some debate as to the correct operation of the site, though it appeared to be safe for fish passage during all evaluations. 


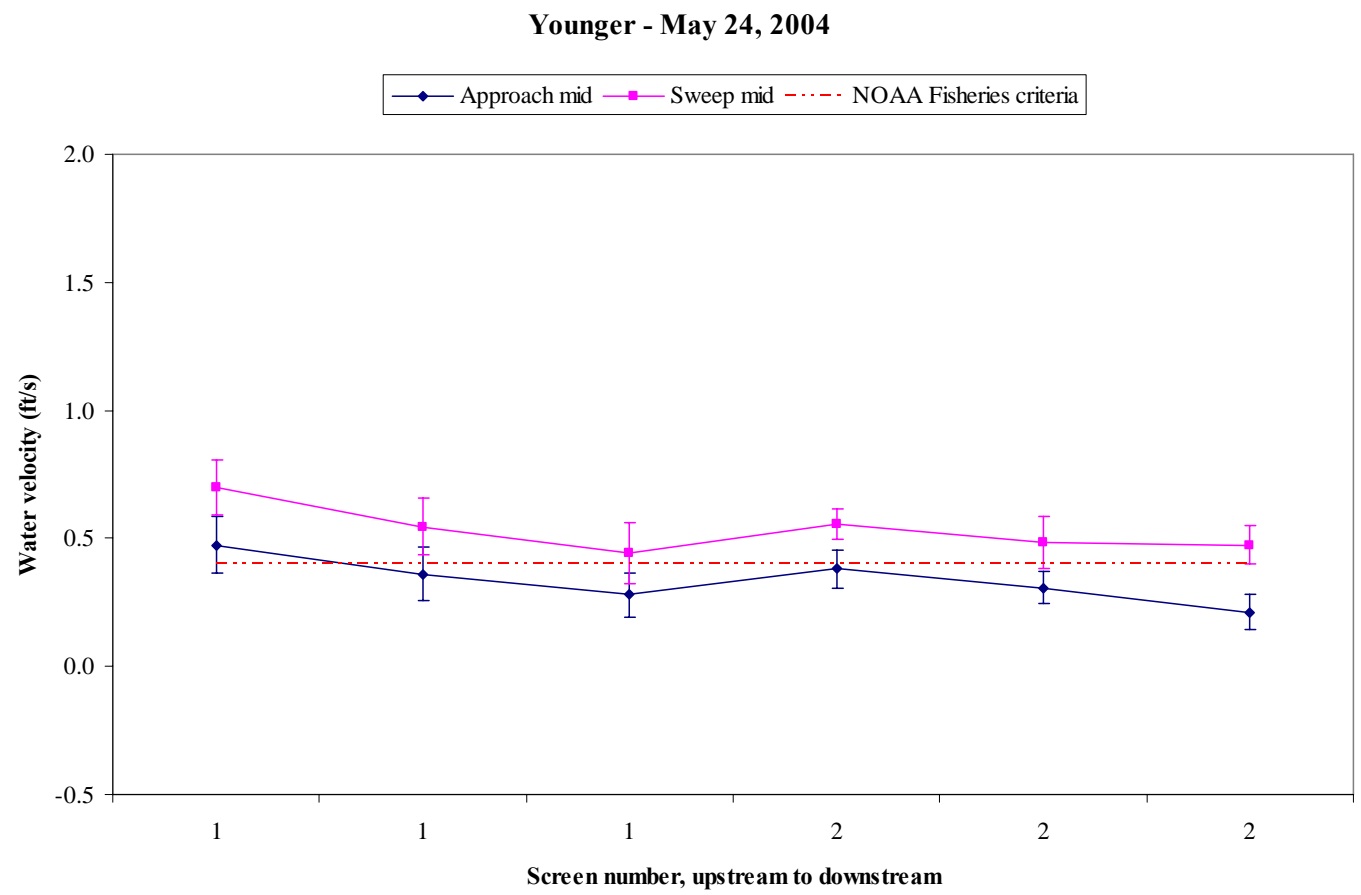

Figure 73. Water velocities and sediment depths at Younger in May 2004. Error bars show turbulence ( \pm the root-mean-squared (RMS)) at each point.

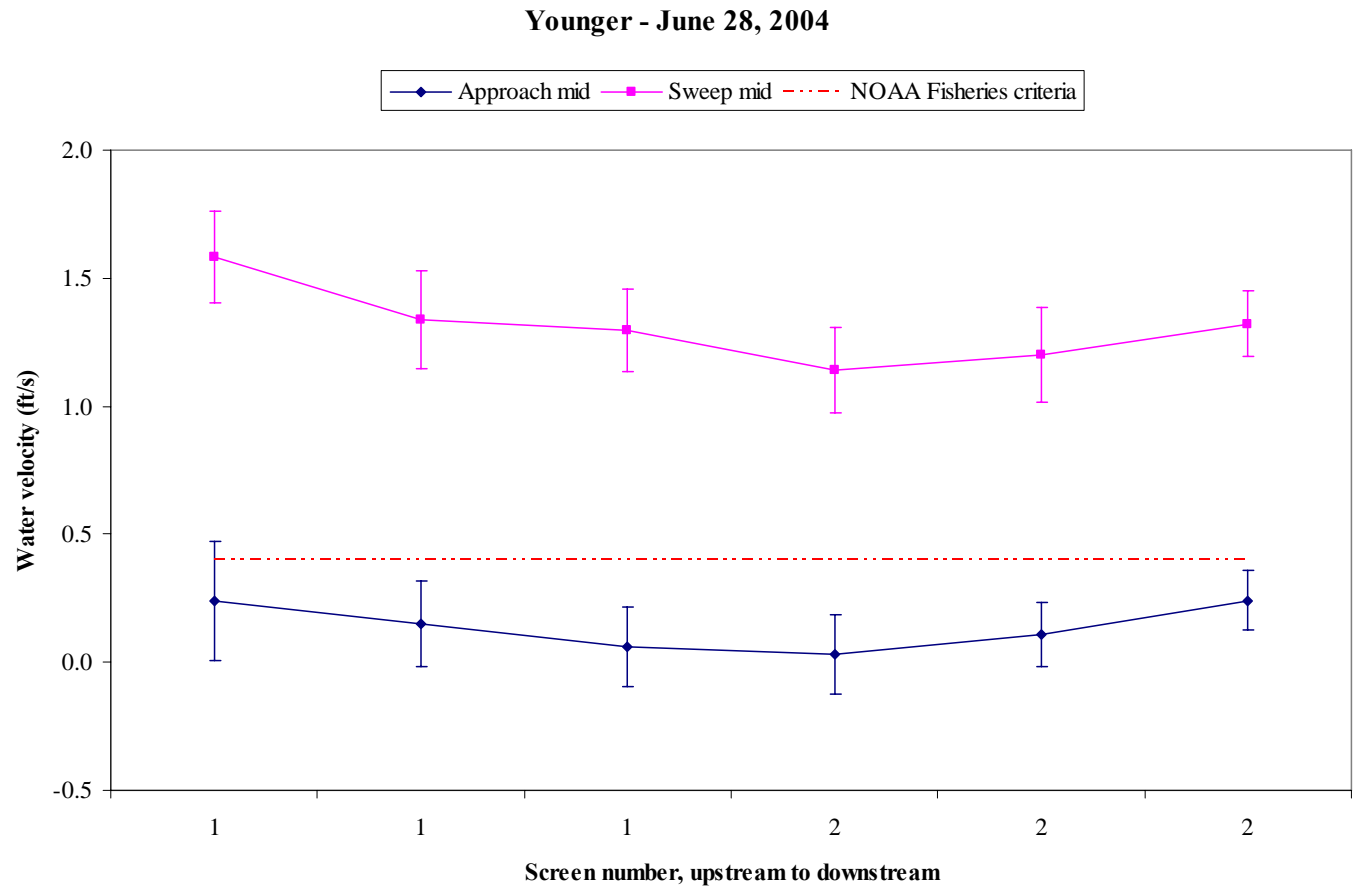

Figure 74. Water velocities at Younger in June 2004. Error bars show turbulence ( \pm the root-mean-squared (RMS)) at each point. 


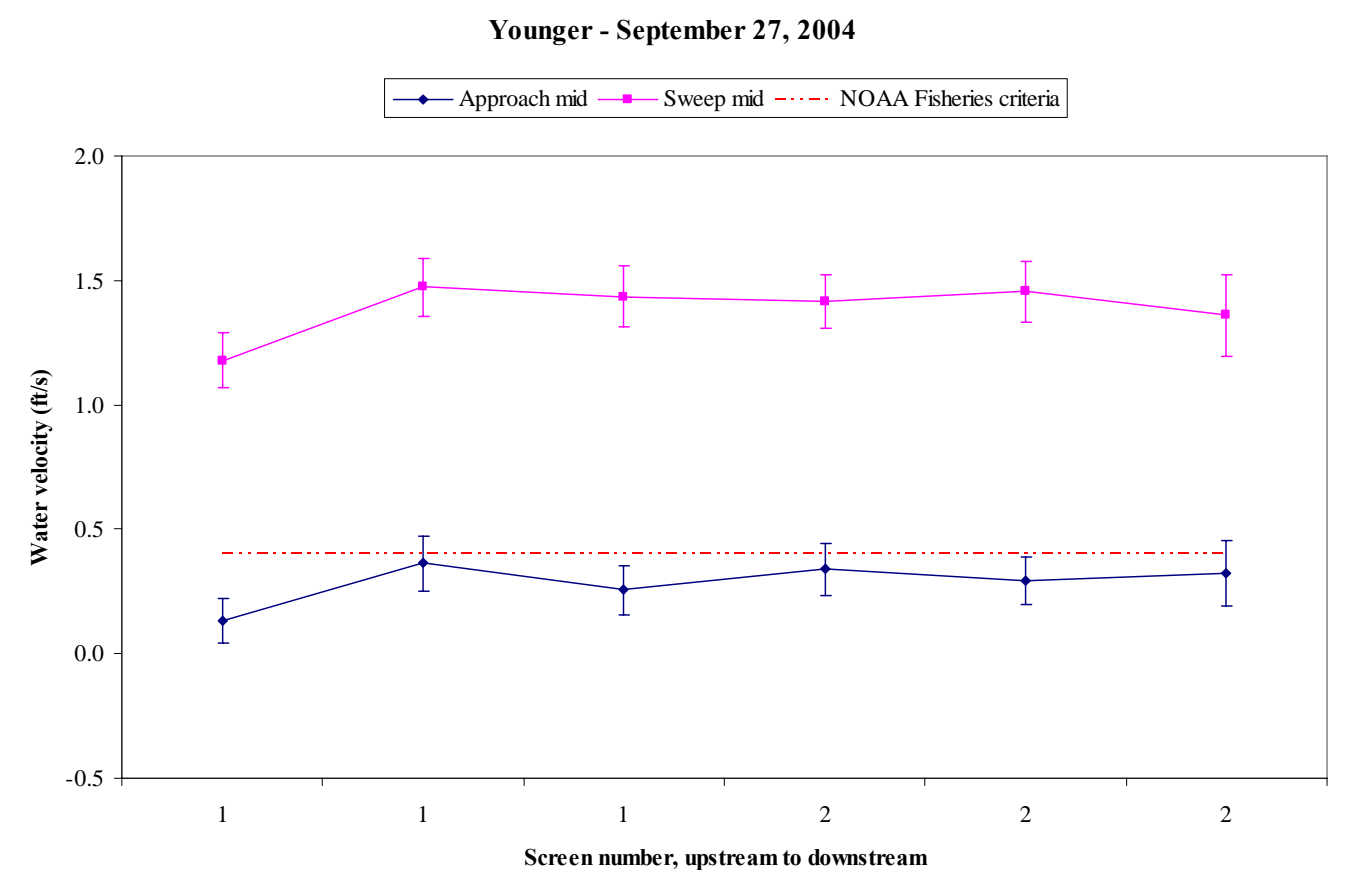

Figure 75. Water velocities at Younger in September 2004. Error bars show turbulence $( \pm$ the root-mean-squared (RMS)) at each point.

\subsection{Vertical Traveling Screen}

\section{Gleed}

The Gleed site was evaluated on May 26, July 1, and September 23, 2004. In May, June, and September, 63, 50, and 75\% of approach values met NOAA Fisheries criteria of less than or equal to $0.4 \mathrm{ft} / \mathrm{s}$, respectively (Figures 76 through 78). Aside from fast water, fish encountering this site also had to deal with highly turbulent water, without a clear trajectory. Sweep velocities were not always greater than approach velocities and did not increase towards the downstream end of the site. The video survey from the July evaluation showed a school of fish near screen 2 that could barely hold in the current, some of which were being swirled around by it. Conditions in July were aggravated by the fact that a representative of the ditch company opened a gate to pull in more water just prior to our taking velocity measurements, so the measurements probably represent a worst-case scenario.

In July, submergence was down to less than $50 \%$ and the water that flowed over the bypass slot fell onto approximately 2 in of water over concrete because the boards that usually create a plunge pool there had been washed out. We were informed that the diversion dam had washed out during the winter and that was the cause of the low submergence. This dam was restored at some point between the July and September surveys.

Ray Gilmour was notified on July 1 concerning the high approach velocities at $50 \%$ of the measured points in July and about the lack of a plunge pool below the bypass. On July 6 boards were installed below the bypass to restore the plunge pool, but there was nothing he could do about the velocities. The design of this site allows for approach velocities to be controlled to some extent by metal plates that are located between the screens and the channel. Gaps between these plates allow water to move in toward 
the screens, but in such concentrated locations that the approach velocities can be quite high at times. Gleed has had chronic problems with high approach velocities and very turbulent water near the screens. An evaluation of the hydraulics associated with the plates and the screens may lead to a better solution to these problems.

There were no problems with sediment buildup at this site, although there seemed to be more floating woody debris than in past years. The screen material was in good condition during all surveys.

Gleed - May 26, 2004

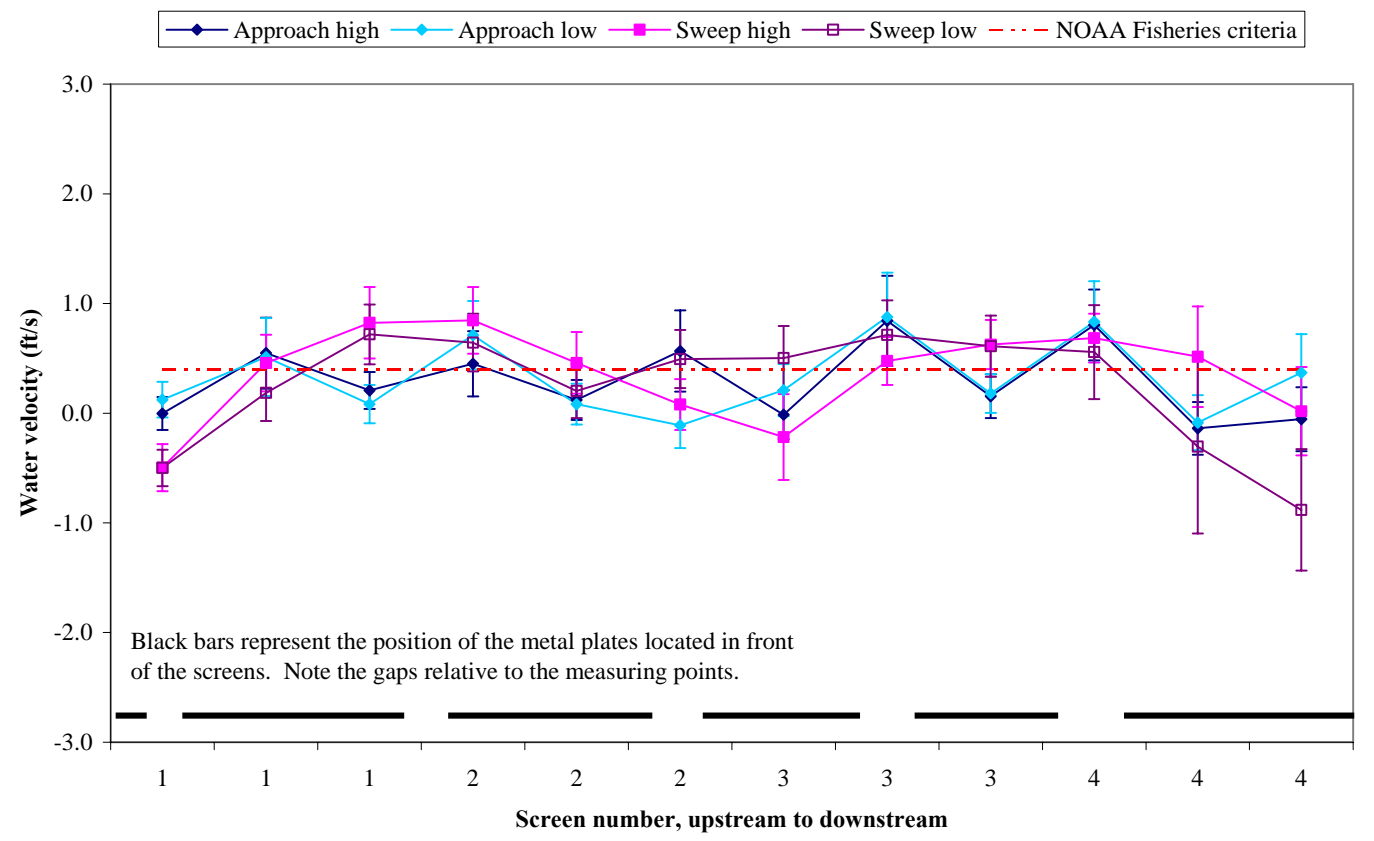

Figure 76. Water velocities and sediment depths at Gleed in May 2004. Error bars show turbulence ( \pm the root-mean-squared (RMS)) at each point. 


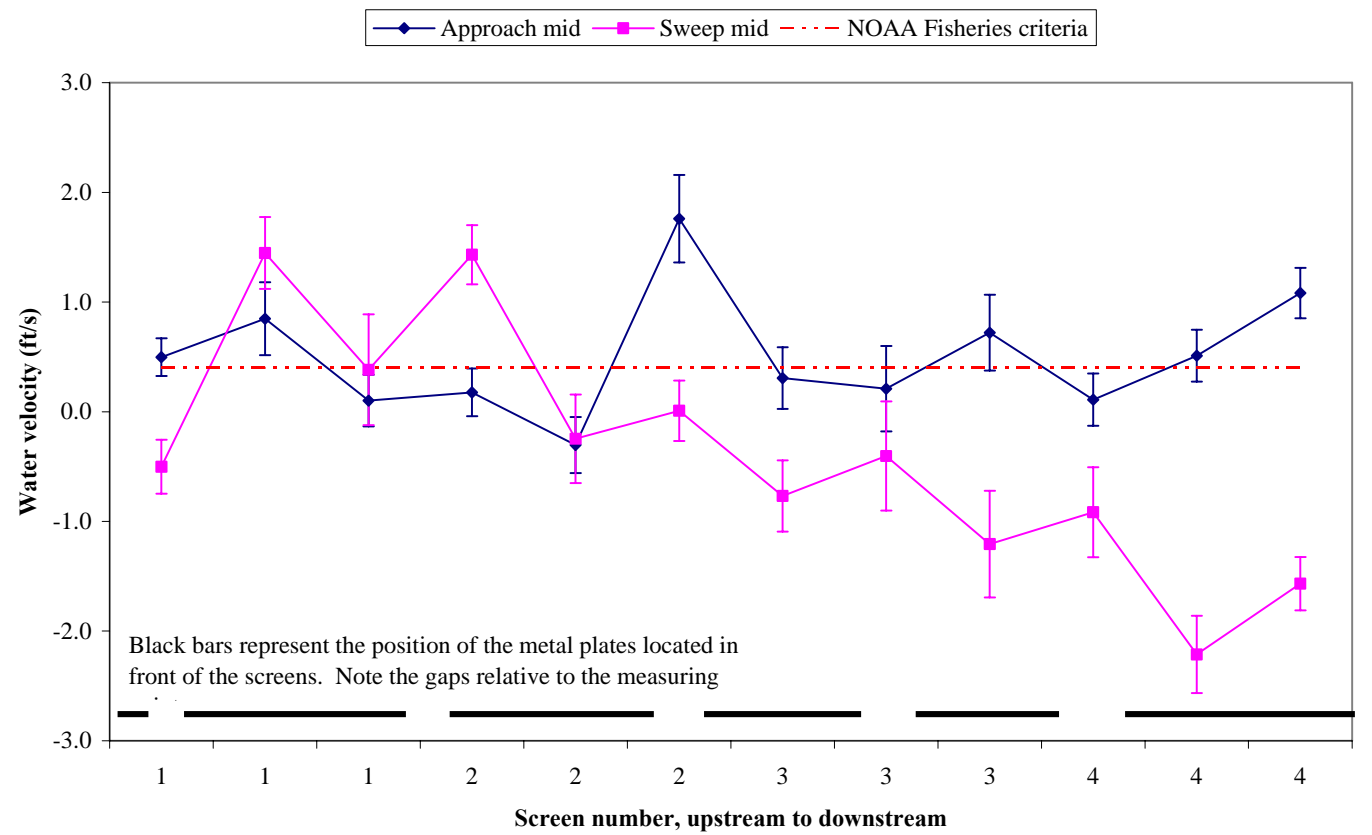

Figure 77. Water velocities and sediment depths at Gleed in July 2004. Error bars show turbulence ( \pm the root-mean-squared (RMS)) at each point.

Gleed - September 23, 2004

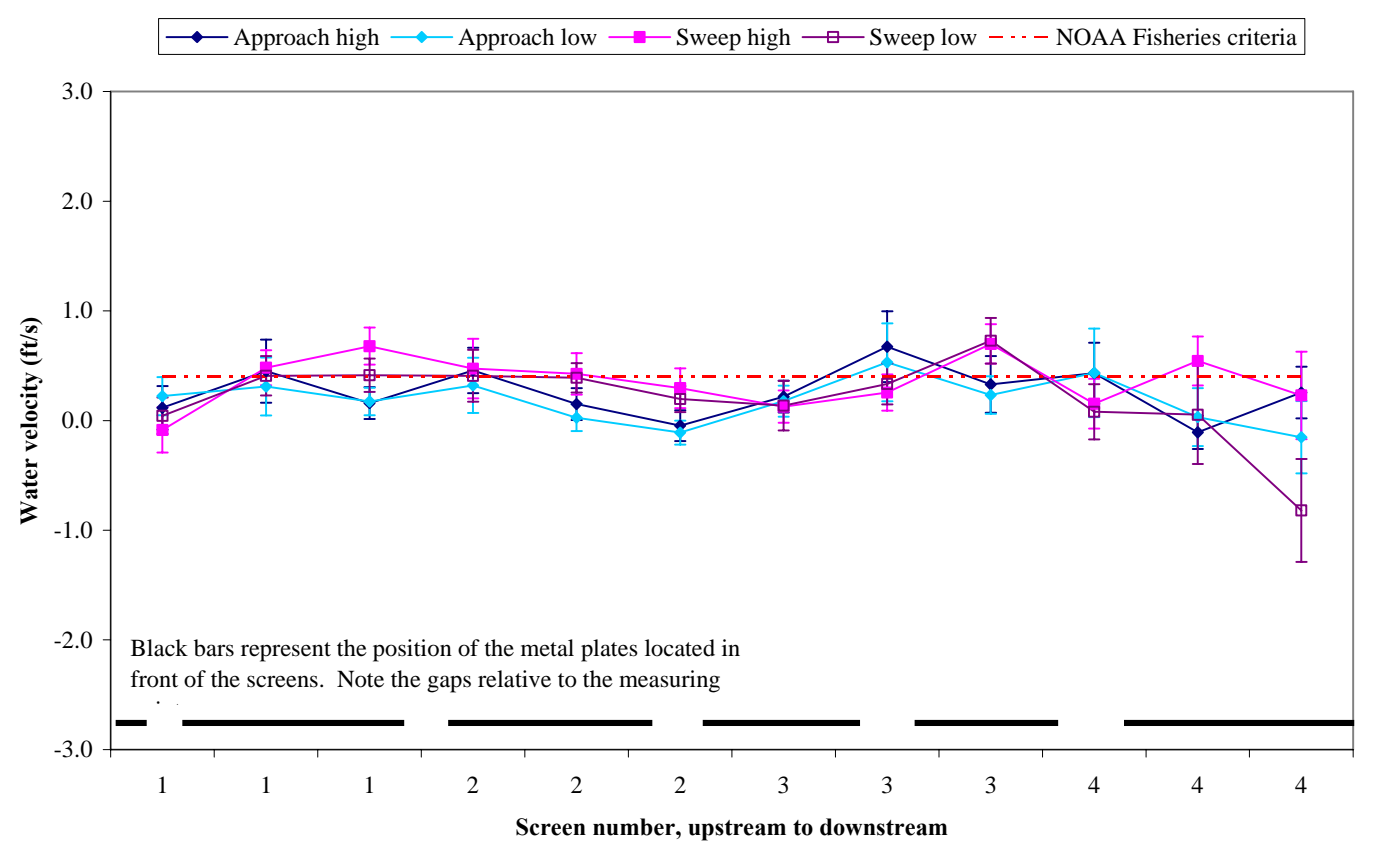

Figure 78. Water velocities and sediment depths at Gleed in September 2004. Error bars show turbulence ( \pm the root-mean-squared (RMS)) at each point. 


\subsection{Conclusions}

The 2004 evaluations of 25 Phase II fish screen facilities in the Yakima River Basin by PNNL indicated that the facilities were generally designed, constructed, operated, and maintained to effectively provide fish a safe and efficient return to the river. Sweep velocities were generally higher than approach velocities and lower than bypass velocities, which should provide fish with safe passage back into the river without delays.

Most screens were well maintained and properly sealed to prevent fish entrainment and injury, although some potential problems were identified at some screen sites. These included missing caulking at flat-plate screens (e.g., Yakima-Tieton), excessive accumulation of debris at some of the sites (e.g., Toppenish Pump), and low submergence and high approach velocities at a few of the sites (e.g., Naches-Selah). The lack of caulking creates gaps that could potentially entrain fish, while debris buildup could create habitat for predators and, in some cases, inhibit the ability of the site to function properly. Approach velocities that exceed the NOAA Fisheries criteria of $0.4 \mathrm{ft} / \mathrm{s}$ could lead to fish entrainment or injury. Low submergence aggravates problems when irrigators attempt to pull more water through less of the screen surface area. Low submergence may also lead to increased debris buildup in the forebays. The automated cleaning brushes at flat-plate screen sites generally functioned properly; chains and other moving parts were well-greased and operative. Drum screen sites generally functioned properly to roll debris into the canal.

One site in particular, Gleed, has had chronic problems meeting NOAA Fisheries approach criteria over the past several years. For five of the past six years, more than $10 \%$ of the measured approach velocities for the season have been greater than $0.4 \mathrm{ft} / \mathrm{s}$ at Gleed. In addition to high approach velocities, fish passing through this site have to deal with highly turbulent water without a clear trajectory. Because of these problems, we recommend that this site be considered for redesign or replacement. Naches-Selah has had similar problems meeting approach velocity criteria for the past several years. On average, 27\% of the measured approach velocities for the season have been greater than $0.4 \mathrm{ft} / \mathrm{s}$ for the past six years. We recommend that this site also be considered for redesign.

Continued periodic screen evaluations will increase the effectiveness of screen operation and maintenance practices by confirming the effectiveness (or ineffectiveness) of screen operating procedures at individual sites. The problem-tracking protocol can assist in this process by making the agencies responsible for operations and maintenance more accountable for proper maintenance and operation of the sites and by flagging sites that may need more attention. Where procedures are being followed and problems still occur, evaluation results can be used to suggest means to better protect fish at screening facilities. There has been a progressive improvement in the maintenance and effectiveness of fish screen facilities in the Yakima River Basin during the past several years, in part, as a result of regular screen evaluations and the rapid feedback of information necessary to improve operations and design of these important fish protection devices. 


\subsection{References}

Abernethy C.S., D.A. Neitzel, and E.W. Lusty. 1990. Velocity Measurements at Three Fish Screen Facilities in the Yakima River Basin, Washington, Summer 1989. DOE/BP-01830-10, prepared by Pacific Northwest Laboratory for the Division of Fish and Wildlife, Bonneville Power Administration, Portland, Oregon.

Abernethy C.S., D.A. Neitzel, and W.V. Mavros. 1996. Movement and Injury Rates for Three Life Stages of Spring Chinook Salmon Oncorhynchus tshawytscha: : A Comparison of Submerged Orifices and an Overflow Weir for Fish Bypass in a Modular Rotary Drum Fish Screen. DOE/BP-62611-5, prepared by Pacific Northwest National Laboratory for the Division of Fish and Wildlife, Bonneville Power Administration, Portland, Oregon.

Blanton S.L., G.A. McMichael, and D.A. Neitzel. 1999. Washington Phase II Fish Diversion Screen Evaluations in the Yakima River Basin, 1998. DOE/BP-62611-15, prepared by Pacific Northwest National Laboratory for the Division of Fish and Wildlife, Bonneville Power Administration, Portland, Oregon.

Blanton S.L., D.A. Neitzel, and C.S. Abernethy. 1998. Washington Phase II Fish Diversion Screen Evaluations in the Yakima River Basin, 1997. DOE/BP-00029-5, prepared by Pacific Northwest National Laboratory for the Division of Fish and Wildlife, Bonneville Power Administration, Portland, Oregon.

Bryant F.G. and Z.E. Parkhurst. 1950. Survey of the Columbia River and Its Tributaries; Part 4: Area III Washington Streams from the Klickitat and Snake Rivers to Grand Coulee Dam, with Notes on the Columbia and Its Tributaries Above Grand Coulee Dam. Special Scientific Report: Fisheries No. 37, U.S. Fish and Wildlife Service, U.S. Department of the Interior, Washington, D.C.

Carter J.A., G.A. McMichael, and M.A. Chamness. 2002. Yakima River Basin Phase II Fish Screen Evaluations, 2001. DOE/BP-00000652-8, prepared by Pacific Northwest National Laboratory for the Division of Fish and Wildlife, Bonneville Power Administration, Portland, Oregon.

Chamness M.A., E.V. Arntzen, G.A. McMichael, and P.S. Titzler. 2001. Washington Phase II Fish Diversion Screen Evaluations in the Yakima River Basin, 2000. DOE/BP-00000652-3, prepared by Pacific Northwest National Laboratory for the Division of Fish and Wildlife, Bonneville Power Administration, Portland, Oregon.

McMichael G.A., J.A. Vucelick, C.S. Abernethy, and D.A. Neitzel. 2004. "Comparing Fish Screen Performance to Physical Design Criteria.” Fisheries 29(7):10-16.

National Marine Fisheries Service (NMFS). 1995. Juvenile Fish Screen Criteria. National Marine Fisheries Service Environmental \& Technical Services Division, Portland, Oregon.

Neitzel D.A., C.S. Abernethy, and E.W. Lusty. 1986. A Fisheries Evaluation of the Richland and Toppenish/Satus Fish Screening Facilities, Spring 1986. DOE/BP-01830-2, prepared by the Pacific Northwest Laboratory for the Division of Fish and Wildlife, Bonneville Power Administration, Portland, Oregon. 
Neitzel D.A., C.S. Abernethy, and E.W. Lusty. 1990a. A Fisheries Evaluation of the Wapato, Sunnyside, and Toppenish Creek Fish Screening Facilities, Spring 1988. DOE/BP-01830-6A, prepared by the Pacific Northwest Laboratory for the Division of Fish and Wildlife, Bonneville Power Administration, Portland, Oregon.

Neitzel D.A., C.S. Abernethy, and E.W. Lusty. 1990b. A Fisheries Evaluation of the Westside Ditch and Wapato Canal Fish Screening Facilities, Spring 1989. DOE/BP-01830-8, prepared by the Pacific Northwest Laboratory for the Division of Fish and Wildlife, Bonneville Power Administration, Portland, Oregon.

Neitzel D.A., C.S. Abernethy, E.W. Lusty, and L.A. Prohammer. 1985. A Fisheries Evaluation of the Sunnyside Canal Fish Screening Facility, Spring 1985. DOE/BP-01830-1, prepared by the Pacific Northwest Laboratory for the Division of Fish and Wildlife, Bonneville Power Administration, Portland, Oregon.

Neitzel D.A., C.S. Abernethy, E.W. Lusty, and S.J. Wampler. 1988. A Fisheries Evaluation of the Richland and Wapato Canal Fish Screening Facilities, Spring 1987. DOE/BP-01830-3, prepared by the Pacific Northwest Laboratory for the Division of Fish and Wildlife, Bonneville Power Administration, Portland, Oregon.

Neitzel D.A., S.L. Blanton, C.S. Abernethy, and D.S. Daly. 1997. Movement of Fall Chinook Salmon Fry Oncorhynchus tshawytscha: A Comparison of Approach Angles for Fish Bypass in a Modular Rotary Drum Fish Screen. DOE/BP-62611-10, prepared by the Pacific Northwest National Laboratory for the Division of Fish and Wildlife, Bonneville Power Administration, Portland, Oregon.

Northwest Power Planning Council (NPPC). 1984. Fish and Wildlife Program: Measure 704(d). Northwest Power Planning Council, Portland, Oregon.

Northwest Power Planning Council (NPPC). 1987. Fish and Wildlife Program: 1403.4. Northwest Power Planning Council, Portland, Oregon.

Northwest Power Planning Council (NPPC). 1994. Fish and Wildlife Program: Measure 7.10. Northwest Power Planning Council, Portland, Oregon.

Northwest Power Planning Council (NPPC). 2000. Fish and Wildlife Program. Northwest Power Planning Council, Portland, Oregon.

Vucelick J.A., G.A. McMichael, and M.A. Chamness. 2004. Yakima River Basin Phase II Fish Screen Evaluations, 2003. DOE/BP-00000652-16, prepared by the Pacific Northwest National Laboratory for the Division of Fish and Wildlife, Bonneville Power Administration, Portland, Oregon. 